This is a non-peer-reviewed preprint submitted to EarthArXiv

\title{
Global inventories of inverted stream channels on Earth and Mars
}

\author{
Abdallah S. Zaki ${ }^{\mathrm{a}^{*}}$, Colin F. Pain ${ }^{\mathrm{b}}$, Kenneth S. Edgett ${ }^{\mathrm{c}}$,
} Sébastien Castelltort ${ }^{\mathrm{a}}$

a Department of Earth Sciences, University of Geneva, Rue des Maraîchers 13, 1205 Geneva, Switzerland.

b MED_Soil, Departamento de Cristlografía, Mineralogía y Quimica Agrícola, Universidad de Sevilla, Calle Profesor García González s/n, 41012 Sevilla, Spain.

${ }^{\mathbf{c}}$ Malin Space Science Systems, Inc., P.O. Box 910148, San Diego, CA 92191, USA

Corresponding Author: ${ }^{a^{*}}$ Department of Earth Sciences, University of Geneva, Rue des Maraîchers 13, 1205 Geneva, Switzerland. (Abdallah.zaki@etu.unige.ch) 


\section{ABSTRACT}

Data from orbiting and landed spacecraft have provided vast amounts of information regarding fluvial and fluvial-related landforms and sediments on Mars. One variant of these landforms are sinuous ridges that have been interpreted to be remnant evidence for ancient fluvial activity, observed at hundreds of martian locales. In order to further understanding of these martian landforms, this paper inventories the 107 known and unknown inverted channel sites on Earth; these offer 114 different examples that consist of materials ranging in age from Upper Ordovician to late Holocene. These examples record several climatic events from the Upper Ordovician glaciation to late Quaternary climate oscillation. These Earth examples include inverted channels in deltaic and alluvial fan sediment, providing new analogs to their martian counterparts. This global dataset provides environmental context regarding the formation mechanisms and conditions that accompanied channel formation and inversion. There are five documented processes by which channel sediment and valley fill become consolidated and inverted after adjacent floodplain sediments are eroded away: (1) channel fill cementation during near-surface, early diagenesis; (2) channel fill lithification during burial diagenesis in the subsurface; (3) filling of a channel or valley by extrusive volcanism (lavas, tuffs); (4) channel surface armouring of coarse clasts by aeolian and fluvial processes; (5) compaction of bank-forming peat, which can lead to early inversion without removal of floodplain material. On Earth, early diagenesis (shallow surficial cementation) dominates among inverted fluvial channels (59\%), volcanism is an important contributor (23\%), and deep burial diagenesis, surface armouring, compaction of bank-forming peat are comparatively minor $(11 \%, 6 \%$, and $1 \%$ respectively). Water erosion, wind erosion, and exhumation due to tectonic activity play an important role in removing the surrounding terrain, leaving the channel deposits standing as a ridge. Wind erosion rates involved in causing topographic inversion range from $10 \mathrm{~mm} /$ year in the Bodélé Depression, Chad, to $0.21 \mathrm{~mm} / \mathrm{year}$ in the Kumtagh Desert, China. These observations have important implications for understanding the formation and paleoclimate associated with similar landforms on Mars. Shallow, nearsubsurface cementation of channel sediment could be prevalent on Mars due to a favorable climate like that of where they occur on Earth (tropical and subtropical climates), particularly because most Martian examples are not capped by volcanic materials and because tectonism, as compared to Earth, plays a negligible role in returning buried materials to the surface. Studying inverted channels on Mars at the global scale will bring new information on the early climate of Mars, 
particularly transition from wet to dry conditions. Finally, we propose that inverted deltaic deposits, which occur around the margins of the Pleistocene Tushka paleolake, in Egypt, are an excellent terrestrial analogue for fan-shaped deposits in relief inversion on Mars, particularly the deltaic deposits in Jezero crater, the landing site for NASA's Mars 2020 rover.

Keywords: inverted topography; inverted channels; sinuous ridges; Mars; Earth analogue.

\section{INTRODUCTION}

The term "inverted channel" describes remnant fluvial channel sediment or channel fill that has become more elevated than its surrounding terrain that obtained this form owing to differential erosion (LeConte, 1880, 1886; Miller, 1937; Giegengack, 1968; Pain and Ollier, 1995; Pain et al., 2007; Williams et al., 2007; Zaki et al., 2018). Inverted channels were first introduced into the scientific literature by Whitney (1865), who reported on old river beds in the Sierra Nevada, California, "where mountain tops are made up of once-flowing stream beds" (Hill, 2006). His observations led LeConte $(1880,1886)$ to study these features in detail. LeConte observed that fluvial deposits protected by lava flows were more resistant to erosion than the adjacent valley slopes. Then, Hörner (1932) identified inverted channels in the Lop-Nor region, China. Miller (1937) next identified another inverted drainage system - today presented, as he said, "in basrelief"- -in the Nejd area eastern Saudi Arabia. He identified cementation of channel sediments as an agent for the relief inversion. Figure 1 shows spectacular examples of inverted paleorivers in the Sahara (Giegengack, 1968; Zaki et al., 2018) and Utah deserts (Williams et al., 2007). On Earth, study of inverted channels, where they occur, are a key part of past climate reconstruction because they are coupled with paleodrainage systems (Beresford-Jones et al., 2009; Wang et al., 2015; Matter et al., 2016; Williams et al., 2007; Williams et al., 2009; Zaki et al., 2020). Some of these features also have an economic potential (e.g. sedimentary uranium; Pain and Ollier, 1995; Hou et al., 2007).

Spacecraft missions have captured images of hundreds of sinuous ridges on Mars, many of which have been interpreted to be a record of ancient fluvial processes (Fig. 2; Table 1; Williams, 2007; Williams et al., 2011; Davis et al., 2019). Research efforts on this topic since 1999 (data from orbiters Mars Global Surveyor, Mars Odyssey, Mars Express, Mars Reconnaissance Orbiter, Mangalyaan, and Trace Gas Orbiter) have focused on detailed studies of landforms interpreted to 
be the product of the erosional inversion of fluvial, alluvial, and deltaic landforms. Malin and Edgett (2003) identified inverted landforms associated with deltaic features in the Eberswalde crater delta. More investigations on inverted channels have been carried out in Gale crater (e.g., Thomson et al., 2011), northwest Meridiani (e.g., Wiseman et al., 2010), Aeolis Dorsa (e.g., Burr et al., 2010; Kite et al., 2015; Jacobsen and Burr, 2017), Medusae Fossae Formation (e.g., Burr et al., 2006), and Miyamoto crater (Newsom et al., 2010), to name a few. Emphasizing sinuous ridges that were interpreted to have previously been fluvial valleys or channels, an early global inventory by Williams (2007) — updated here in Fig. 2 - captured some of this abundance. More recently, Davis et al. $(2016,2019)$ described an even greater abundance of candidate inverted channels occurring within a single heavily cratered region, Arabia Terra. Fawdon et al. (2018) and Adler et al. (2018) identified inverted topographic features in the Hypanis Valles region, including alluvial fans and channels. Williams et al. (2018) investigated the formational mechanisms of 20 large inverted channel sites on Mars. Before these global and regional surveys, Pain et al. (2007) documented a variety of inverted Martian landforms. Figure 3 gives some common examples on Mars. As an important supplement to the record of fluvial channels on Mars, in recent years it has become clear that martian sinuous ridges provide an essential record of early Martian climate (Kite et al., 2015; Kite et al., 2019; Davis et al., 2019); the study of such landforms in detail contributes to addressing questions about the climate of early Mars and its transition to the modern, hyperarid setting we find today.

Such landforms on Mars are at present accessible only through spacecraft missions and remote robotic exploration. For this reason, the study of Earth analogues has become firmly established as a strategy to enable the interpretation of these landforms. Earth analogue studies provide vital observations that can be applied to the interpretation of features observed on Mars using images acquired by flyby, orbiting, descending, landed, or mobile landed platforms (Chapman, 2007; Baker et al., 2015). In 2020, multiple new Mars missions (orbiters and landers) will be launching, including NASA's Mars 2020, ESA/Roscosmos's ExoMars 2020, UAE's Hope, and China's 2020 Mars Mission. Investigation of inverted fluvial landforms is the main task of the NASA's Mars 2020 rover (Williford et al., 2018) that will land in a Jezero crater, which contains lithified deltaic sediment bearing inverted channel forms (Fig. 3d; Goudge et al., 2018). Therefore, a broad synthesis of the processes and conditions that led to the formation of inverted channels on Earth 
provides a fundamental tool to understand ancient martian environments associated with sinuous ridges.
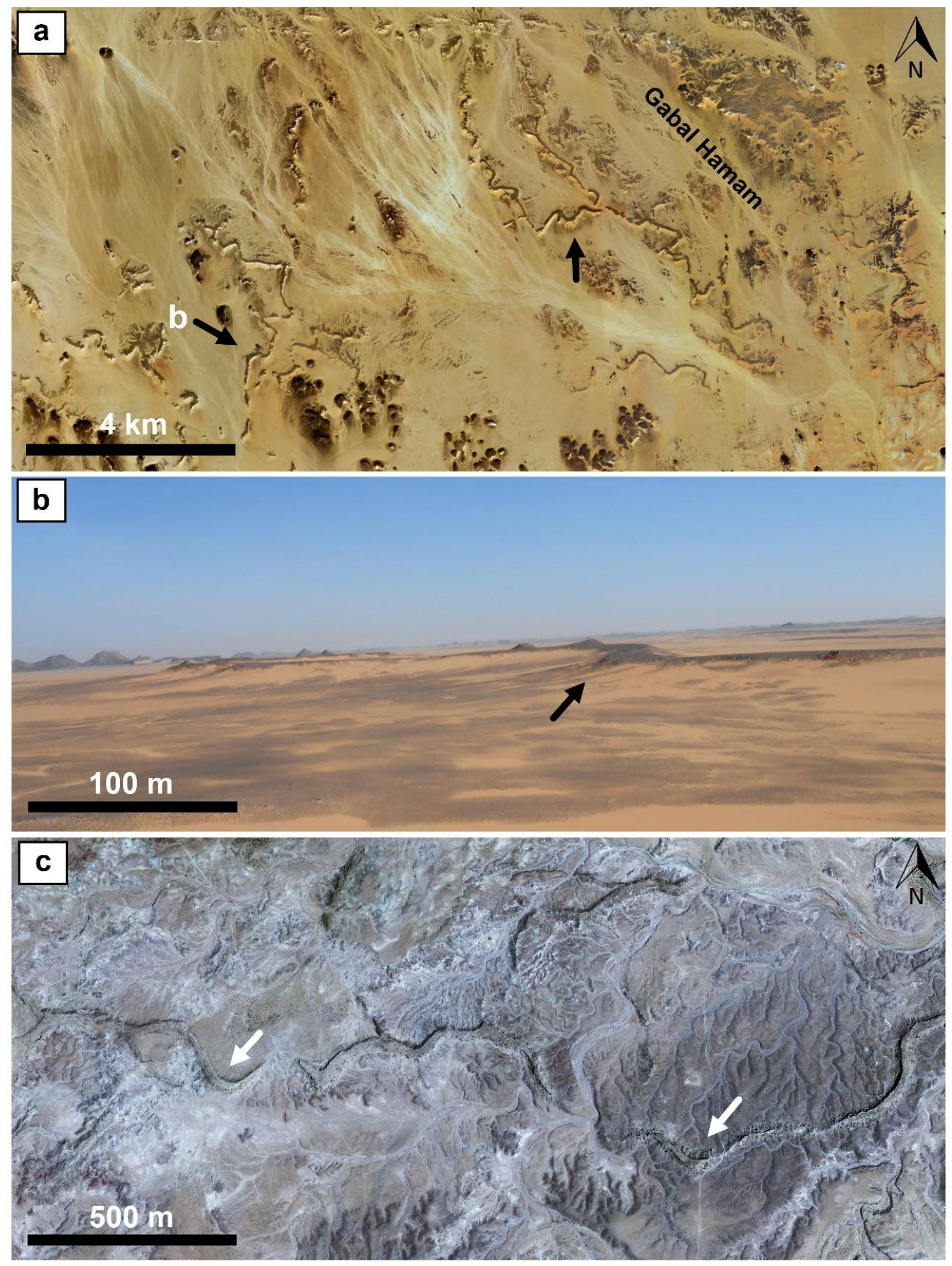

Fig. 1. (a) Satellite image showing the dendritic pattern in inverted relief in the southern part of Egypt (22 56'28.27"N, 32 7'47.69"E) (Image credit: ESRI World Imagery). (b) Field photograph of an inverted channel in Egypt (22 55'7.14"N, 32 4'22.17"E). (c) Satellite image of inverted fluvial ridges deposited during the Cretaceous timer in Utah $\left(38^{\circ} 53^{\prime} 12.69^{\prime \prime} \mathrm{N}, 110^{\circ} 17^{\prime} 42.26^{\prime \prime} \mathrm{W}\right)$ (Image Credit: Google Earth). 
Thus, in this contribution, we review the terminology employed to describe inverted channels, their global distribution, the processes underlying their formation, their general morphological and sedimentological features, and their relative and absolute ages. Further, we end with insights learned from the global synthesis inverted channels and valleys on Earth. This study is an attempt to identify as many as possible of the reported examples of inverted stream channel forms on Earth and constrain their formational scenarios and ages. This work is relevant to addressing fundamental issues on the nature, formation, timescale, and paleoclimate associated with the sinuous ridges on Mars.

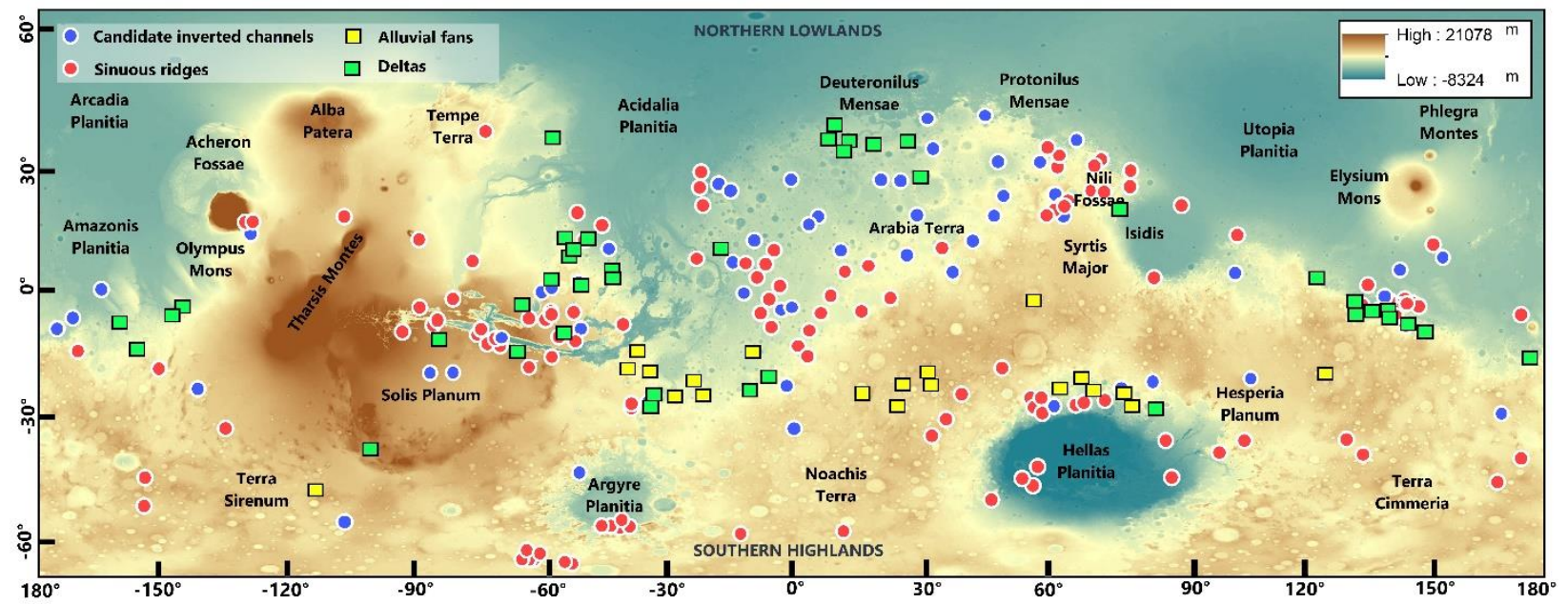

Fig. 2. Distribution of candidate inverted channels on Mars (blue dots; Table 1) and distribution of sinuous ridges of less certain origin (red dots). Distribution of deltas and fluvial fans that have inverted channel bodies. The map was generated from Mars Global Surveyor (MGS) Mars Orbiter Laser Altimeter (MOLA) data (Smith et al., 2001). 

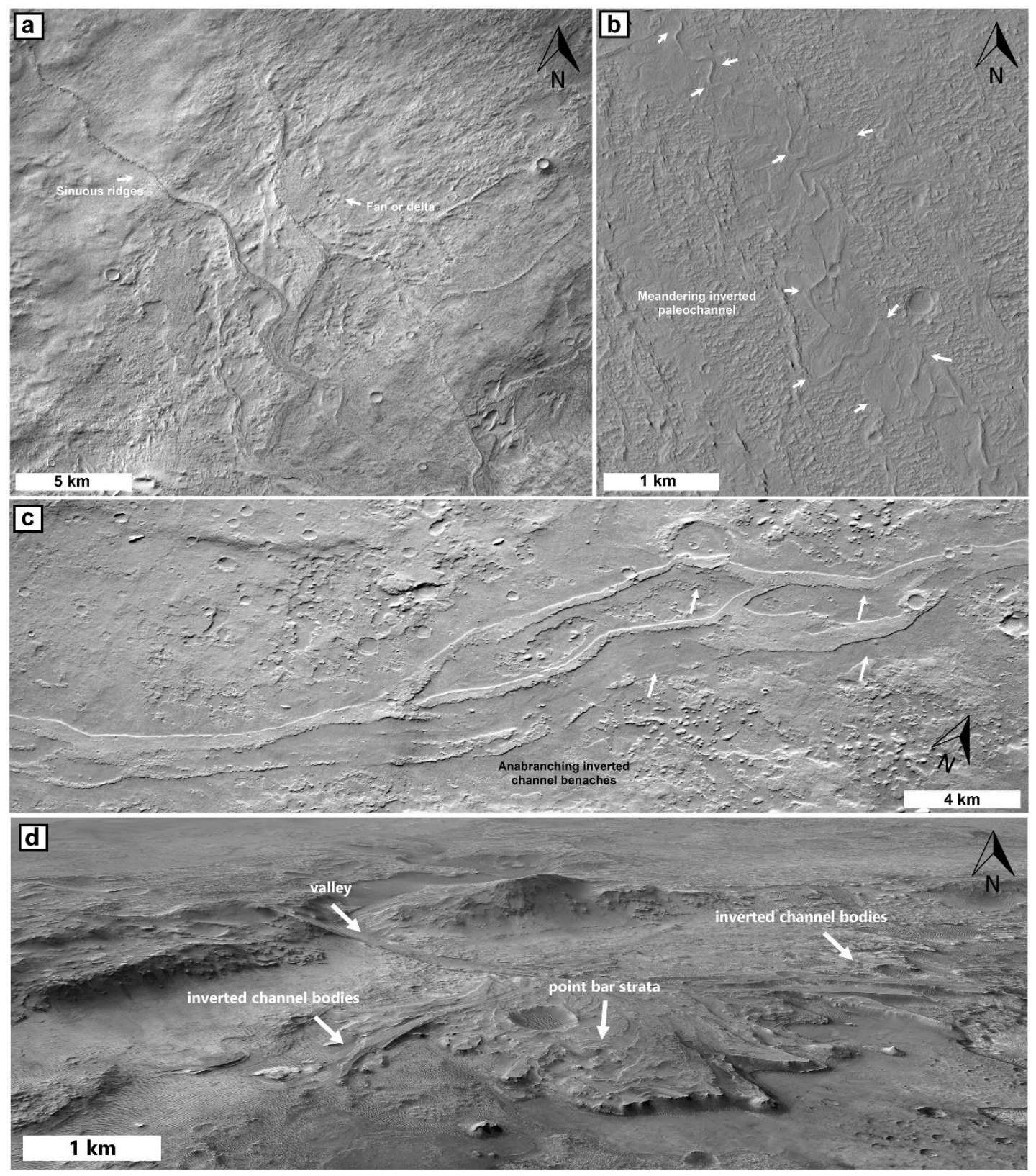

Fig. 3. Examples of inverted fluvial landforms on Mars. (a) Candidate inverted stream channels in a fan or delta in southeast Hellas Planitia $\left(46.5^{\circ} \mathrm{S}, 87.4^{\circ} \mathrm{E}\right)$; portion of Mars Reconnaissance Orbiter (MRO) Context Camera (CTX) image F20_043739_1318_XI_48S273W acquired on 25 November 2015. (b) Portion of an inverted, meandering fluvial sediment system in the Aeolis Dorsa region near $6.0^{\circ} \mathrm{S}, 206.5^{\circ} \mathrm{W}$, described by Matsubara et al. (2015) and others; portion of MRO High Resolution Imaging Science Experiment (HiRISE) image PSP_010322_1740, acquired in October 2008. (c) Portion of the Aram Dorsum inverted fluvial complex in western Arabia Terra near $8.2^{\circ} \mathrm{N}, 11.1^{\circ} \mathrm{W}$, described by Davis et al. (2016), Balme et al. (2015), and others; portion of MRO CTX image G23_027180_1889_XI_08N011W, acquired in May 2012. (d) Perspective view showing inverted channel bodies associated with an inverted deltaic form in Jezero crater $\left(18.5^{\circ} \mathrm{N}, 77.3^{\circ} \mathrm{E}\right)$, the NASA Mars 2020 rover landing site; the image coupled with HiRISE digital terrain model (Credit: NASA / JPL / UA / Seán Doran). 


\section{TERMINOLOGY}

Since the 1800s, numerous local and descriptive terms have been used to refer to inverted fluvial channels and river sediment bodies, including "old-river beds" in Sierra Nevada, California (LeConte, 1880, 1886), "former rivercourses" in Lop-Nor, China (Hörner, 1932), "suspendritic lines" in eastern Saudi Arabia (Miller, 1937). Colton (1937) described a "basaltic sandstone ridge" near the Little Colorado River in Arizona. "Exhumed point bars" described such features in northcentral Texas (Edwards et al., 1983). Multiple terms such as "inverted wadis," "perched ridges," "wadi ridges," and "wadi conglomerate" were given to these features in the Sahara (Giegengack, 1968; Butzer and Hansen, 1968; Haynes, 1980; Embabi, 2004; Zaki and Giegngack, 2016; Giegngack and Zaki, 2017). King (1942) described "gravel-capped ridges," and Girard et al. (2012) used "channelized sandstone bodies" to describe the oldest inverted channel outcrops on Earth. Maizels $(1983,1987,1990)$ called them "raised channel systems" in Oman and Holm (1960) used "inverted courses" to for inverted relief on the Arabian Peninsula. The term "extinct wadis" was given by Wright (1958) in investigations of the Syrian Desert. More terms applied to these features are listed in Table 2.

The issue of terminology also extends to Mars. The terms "sinuous ridges" and "raised curvilinear features" were given to all ridges that exhibit a primarily sinuous pattern (Williams, 2007; Williams et al., 2011; Hayden et al., 2019). Some of these ridges were interpreted to be glacial eskers, glacial moraines, igneous dikes, and sedimentary dikes (Kargel and Storm, 1991, 1992; Pain et al., 2007, Williams, 2007; Burr et al., 2010; Hayden et al., 2019), while many others are interpreted as potential inverted fluvial forms (e.g. Pain et al., 2007; Davis et al., 2016; Williams et al., 2018).

In 2012, the International Astronomical Union (IAU) adopted the term 'serpens' for sinuous features with segments of positive and negative relief along their lengths. As far as we are aware, the first published use of this term was by Williams et al. (2013). Previously, the IAU approved 'dorsa' for positive-relief features (for example for possible eskers or sinuous ridges on Mars) and 'vallis' for negative-relief sinuous features.

Here we use the term "inverted channel" to refer to fluvial deposits that mimic the form of a river channel in a relief inversion setting on Earth. On Mars (Fig. 2, Table 1), in cases for which the 
sedimentary structure has not been captured by spacecraft observations, we use the term "sinuous ridges" according to their planimetric pattern and "candidate inverted channel" for the sinuous ridges that have been interpreted by colleagues to more certainly record fluvial activity based on geomorphological setting and observations of sedimentary structures.

\section{GLOBAL DISTRIBUTION AND ATTRIBUTES}

Searching satellite images and the scientific literature, we identified 107 inverted channel sites on Earth (Fig. 4; Table 2). While undoubtedly an incomplete list, 114 examples far exceeds the usual list of about 9 sites of the most commonly cited Earth examples mentioned in the Mars literature (Miller, 1995; Maizels, 1983, 1987, 1990; Pain and Ollier, 1995; Williams et al., 2007; Burr and Williams et al., 2009; Cuevas Martínez et al., 2010; Zaki et al., 2018). These Earth sites are 41 in Africa, 32 in North America, 11 in Australia, 7 in South America, 13 in Asia, 2 in Europe, and one example lies beneath the southeastern Mediterranean Sea. These sites are in different climate ones; sixty-two sites are in the subtropical zone, 37 sites in the tropical zone, and 8 sites in the temperate zone.

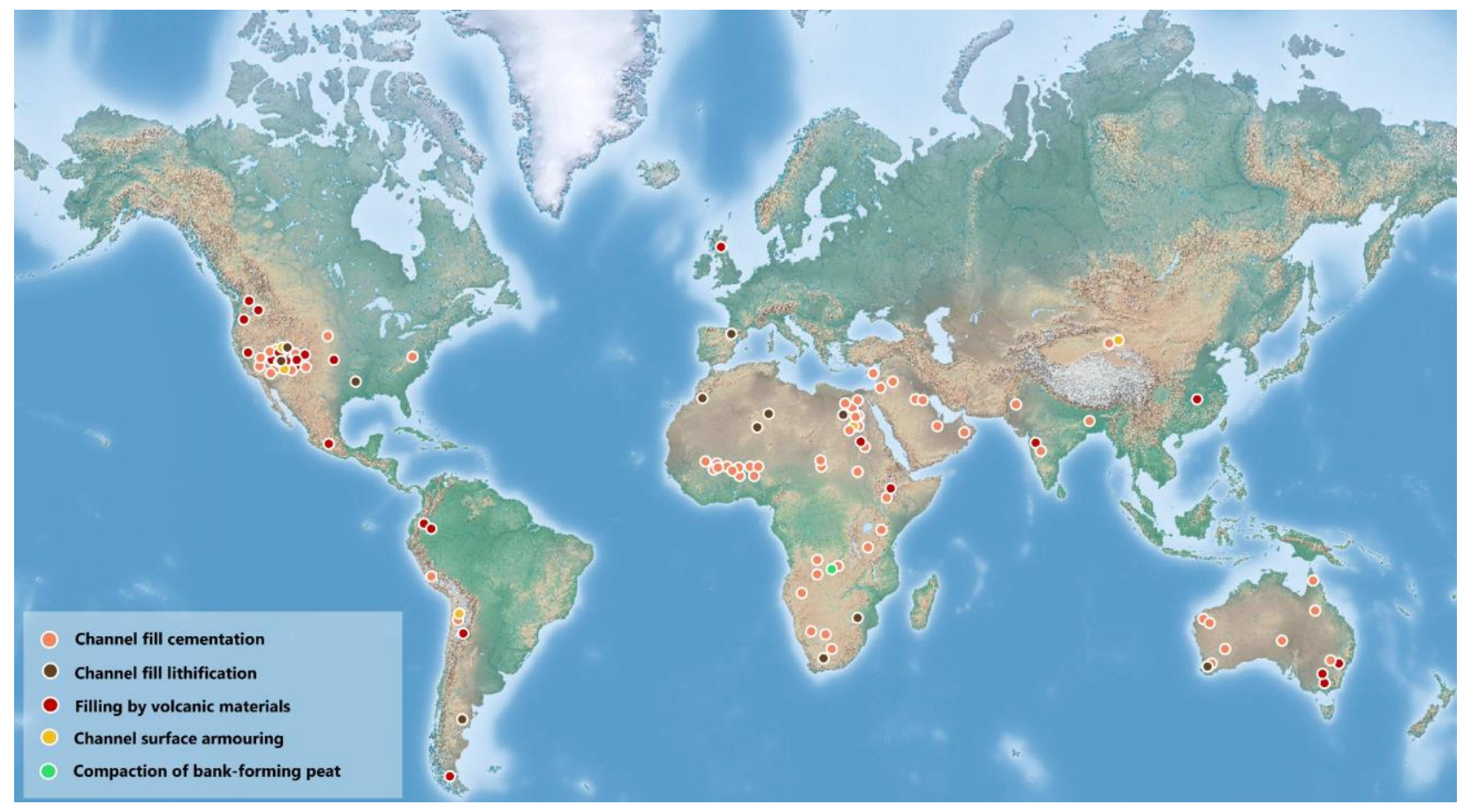

Fig. 4. The global distribution of documented inverted-channel features on Earth (see Table 2). 


\subsection{Africa}

Published investigations regarding inverted fluvial features in Africa started with King (1942) in east Victoria, South Africa, followed by Giegengack (1968), and Butzer and Hansen (1968) in the southern part of the Egyptian Sahara. The latter two examined those fluvial sediment relics in the framework of Quaternary history and Nile evolution. Since then, several additional sites have been identified in Africa (Butzer, 1980; Brookes, 2003; Schuster et al., 2005; Bristow et al., 2009; Girard et al., 2012; Zaki et al., 2018).

Inverted stream channels are widespread in the Sahara. In the eastern Sahara (Egypt and Sudan), there are 9 sites that cover an area of $\sim 40,000 \mathrm{~km}^{2}$ (Fig. 5). They record several episodes of deposition and inversion that began in the Oligocene and continued into the Holocene (Giegengack, 1968; Zaki et al., 2018). Sites deposited during Oligocene and Miocene wet conditions occur west of Ghard Abu Muharik, east of the Dakhla Depression, and west of Esna City (Embabi, 2004; Zaki et al., 2018). Inverted fluvial features in the Fayum Depression were incised during Pliocene flooding after the Messinian Salinity Crisis, and have been subjected to wind erosion since the Pleistocene (Sandford and Arkell, 1929; Embabi, 2004). Inverted channels capped by basalt are documented in the Wadi Awatib and Kordofan in northern Sudan (Schwarz, 1994; Bussert et al., 2018). The inverted channels in southern Egypt and northern Sudan were deposited during late Quaternary (late Pleistocene and Holocene) extreme wet climatic events, the so-called "Late Quaternary climate oscillation" (Giegengack, 1968; Butzer and Hansen, 1968; Zaki et al., 2020). During the late Quaternary climate oscillation, there were abrupt changes in climate over the Sahara that were more common at warmer than at cooler (e.g., Foucault and Stanley, 1989; Hoffmann et al., 2016); that led to several episodes of wet and dry periods causing the incision, cementation, and inversion of these paleorivers. In absence of cemented material and existing of large clasts, the wind deflation removed the fine materials leaving very coarse gravels, cobbles, and boulders in a few outcrops standing as ridges (Giegengack, 1968). In Chad, there are inverted channels located in paleolake Mega-Chad (Schuster et al., 2005, Bristow et al., 2009). In the Kharga Depression, there are inverted channels consisting of sediment deposited during last $225 \pm 40$ years (Bursch, 1988). Considerably older channels and meanders are documented in the Dakhla Depression of Egypt, northern Niger, southern Morocco, and in the Tassili N'Ajjer on the Algeria-Libya border (Brookes, 2003; Girard et al., 2012) (Fig. 6). The sediments of inverted 
channels on the Algeria-Libya border were deposited during the Upper Ordovician (Girard et al., 2012). Sediments of the inverted channels in the Dakhla Depression date from the Upper Cretaceous (Brookes, 2003). The third site has been identified in northern Niger, where there are lithified outcrops of inverted channel sediments that were deposited during the Late Permian (Smith et al., 2015). In southern Morocco, there are several exhumed point bar ridges that were deposited during late Carboniferous (Padgett and Ehrlich, 1976).

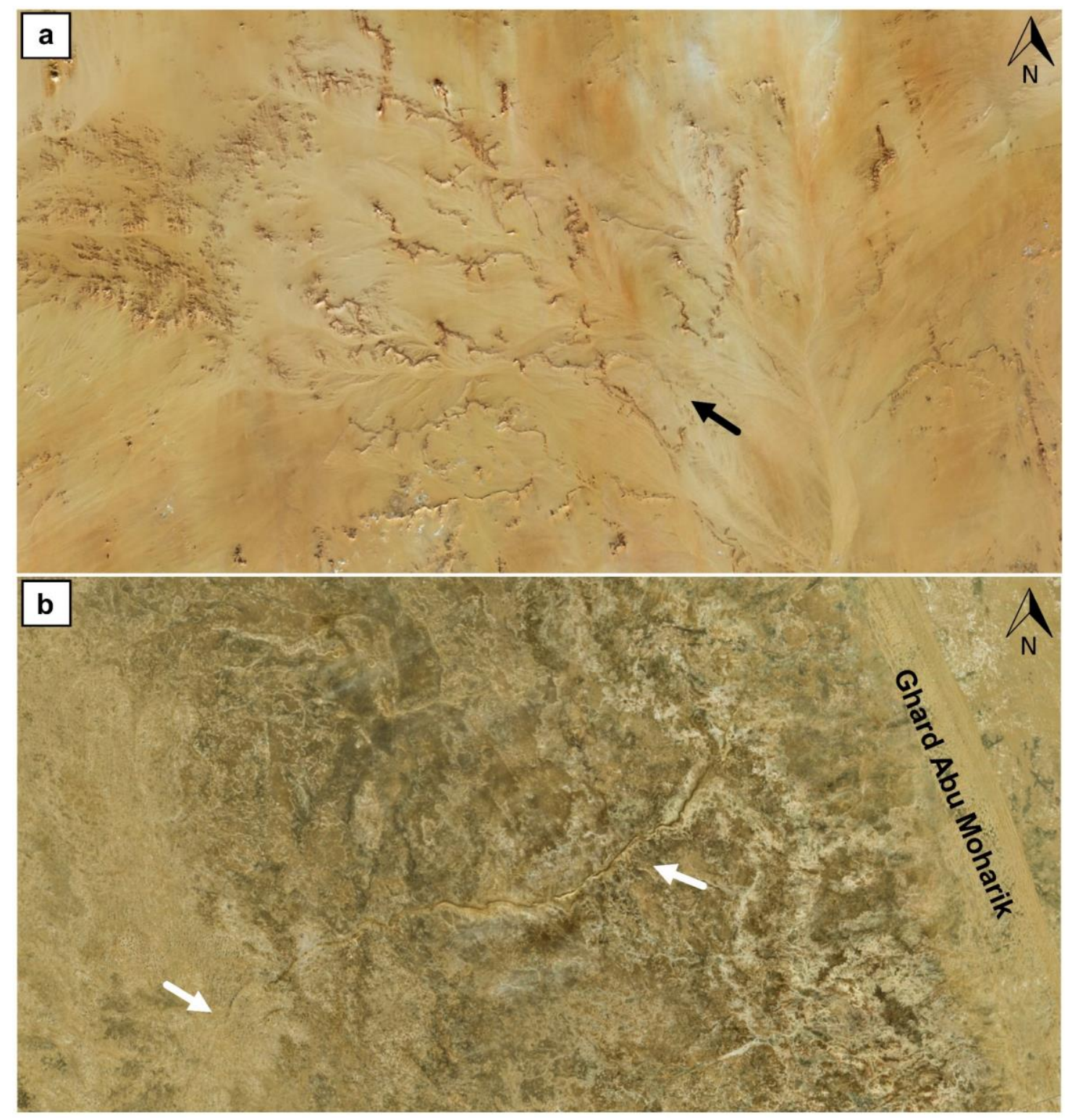

Fig. 5. (a) Satellite image showing an example of inverted dendritic channels in northern Sudan ((21 ${ }^{\circ} 57^{\prime} 03.86^{\prime \prime} N, 31^{\circ} 04^{\prime} 17.36 " E ;$ image credit: ESRI World Imagery). (b) Sinuous ridge with a total length of about $50 \mathrm{~km}$ in the Egyptian Sahara (flow direction from SW to NE; $27^{\circ} 32^{\prime} 54.63^{\prime \prime} \mathrm{N}$, 29²7'39.78"E; image credit: Google Earth). 

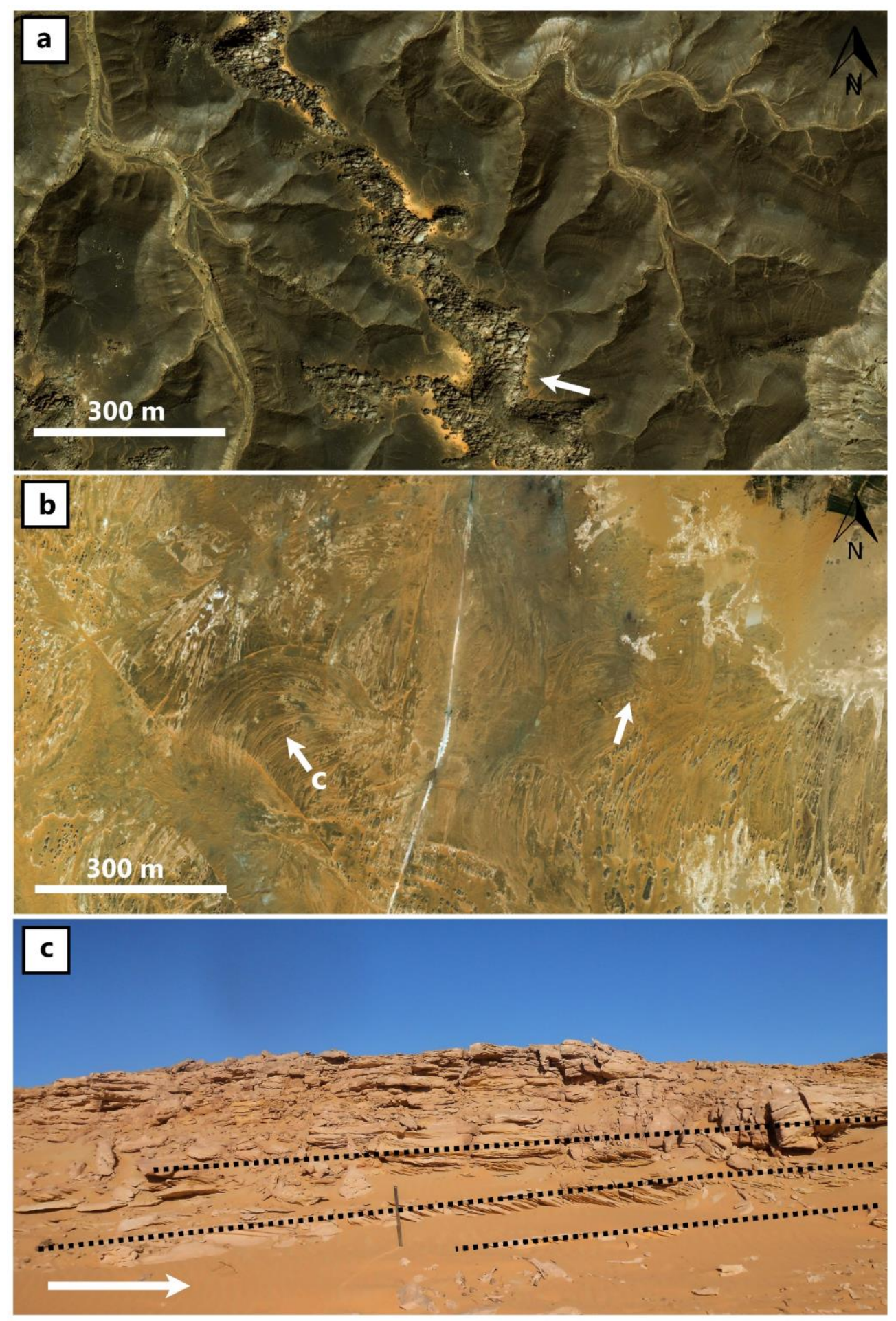

Fig. 6. (a) Channelized sandstone body in the Tassili N'Ajjer, Algeria, deposited during the Upper Ordovician (26ำ'24.96"N, 9¹8'5.03"E) (Image credit: ESRI World Imagery). (b) Exhumed

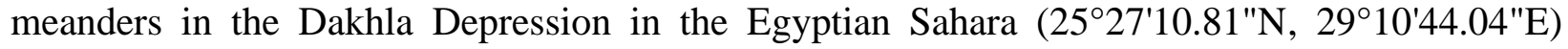
(Image credit: ESRI World Imagery). (c) Field photograph of an exhumed meander - the white arrow indicates the paleoflow direction and the dotted lines are the boundary between crossbedding sets. The stick, $50 \mathrm{~cm}$ long, is a scale. $\left(25^{\circ} 27^{\prime} 10.81^{\prime \prime} \mathrm{N}, 29^{\circ} 10^{\prime} 44.04^{\prime \prime} \mathrm{E}\right)$. 
Our satellite image search led to identification of previously undescribed inverted channels that occur as part of at least 6 deltaic features located around the margins of a middle Pleistocene paleolake site in southern Egypt (Fig. 7). The basin, called paleolake Tushka, would have covered an area of about $\sim 68,000 \mathrm{~km}^{2}$ and was fed by overflow of the Nile coupled with a limited role of the local rainfall (Maxwell et al., 2010).
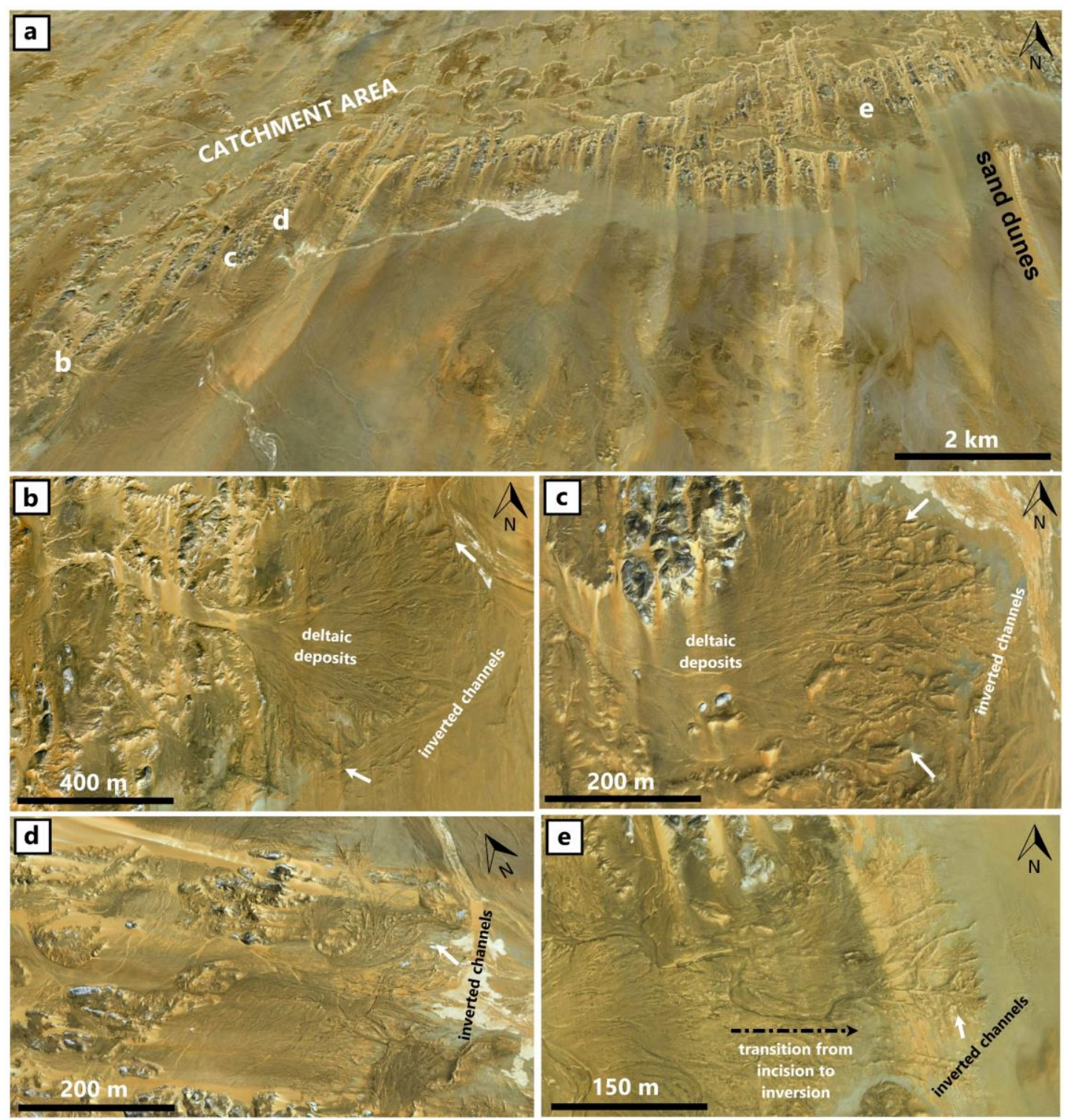

Fig. 7. (a) Portion of paleolake Tushka, Egypt, showing oblique view of a shoreline that hosts deltaic features in relief inversion. (b), (c), (d), and (e) Satellite images showing different forms of inverted channels associated with deltas deposited at the margins of paleolake Tushka during the mid-Pleistocene. The coordinates of the (b), (c), (d), and (e) are $\left(22^{\circ} 47^{\prime} 29.89^{\prime \prime} \mathrm{N}, 30^{\circ} 46^{\prime} 30.73^{\prime \prime} \mathrm{E}\right)$, $\left(22^{\circ} 48^{\prime} 29.48^{\prime \prime} \mathrm{N}, \quad 30^{\circ} 46^{\prime} 48.37^{\prime \prime} \mathrm{E}\right), \quad\left(22^{\circ} 49^{\prime} 04.67^{\prime \prime N}, \quad 30^{\circ} 47^{\prime} 01.68^{\prime \prime} \mathrm{E}\right), \quad$ and $\left(22^{\circ} 51^{\prime} 42.37^{\prime \prime} \mathrm{N}\right.$, 30॰51'39.60"E), respectively. (Credit: ESRI World Imagery). 
Some isolated examples of inverted channels in Africa occur in Lake Turkana, formerly known as Rudolph Lake (Butzer, 1980), where channel sediments (now inverted) were deposited in northen part of the lake when it was $75 \mathrm{~m}$ deeper than present. Additional examples are in Bosutswe in Botswana and the Kalahari Desert, where channel sediments are cemented by calcrete (Nash and McLaren, 2003; Denbow et al., 2008; Shaw, 2009), and at Lake Bogoria in Kenya, where an outflow channel incised by groundwater seepage later became inverted (Renault et al., 2013). The Okavango Delta in Botswana sports some unusual examples in which channels became inverted because their banks consisted of peat that collapsed by burning and compaction (Fig. 8; Ellery et al., 1989; Gumbricht et al., 2004).

Still other examples in Africa consisting of cemented fluvial sediment occur in Ogaden, Ethiopia (Williams et al., 2016), Bulawayo, Zimbabwe (Moore et al., 2009; Moore et al., 2012), the Olduvai Gorge in Tanzania (Blumenschime et al., 2012), and in Burkina Faso (Zeegers and Lecomte, 1992; Chardon et al., 2018). In Namibia, two sites of cemented, inverted fluvial sediments are wellpreserved at Etosha and Oase (Shaw, 2009; Smith and Mason, 1998). Butt and Bristow (2013) studied inverted valleys developed from Paleocene to Pliocene time at 9 sites that extend along $\sim 1,300 \mathrm{~km}$ from western Mali to eastern Burkina Faso. A fossil drainage system has been identified in Upper Jubba Valley, Somalia; the valley at this site was filled by lava and tuff (Abdirahim et al., 1993).

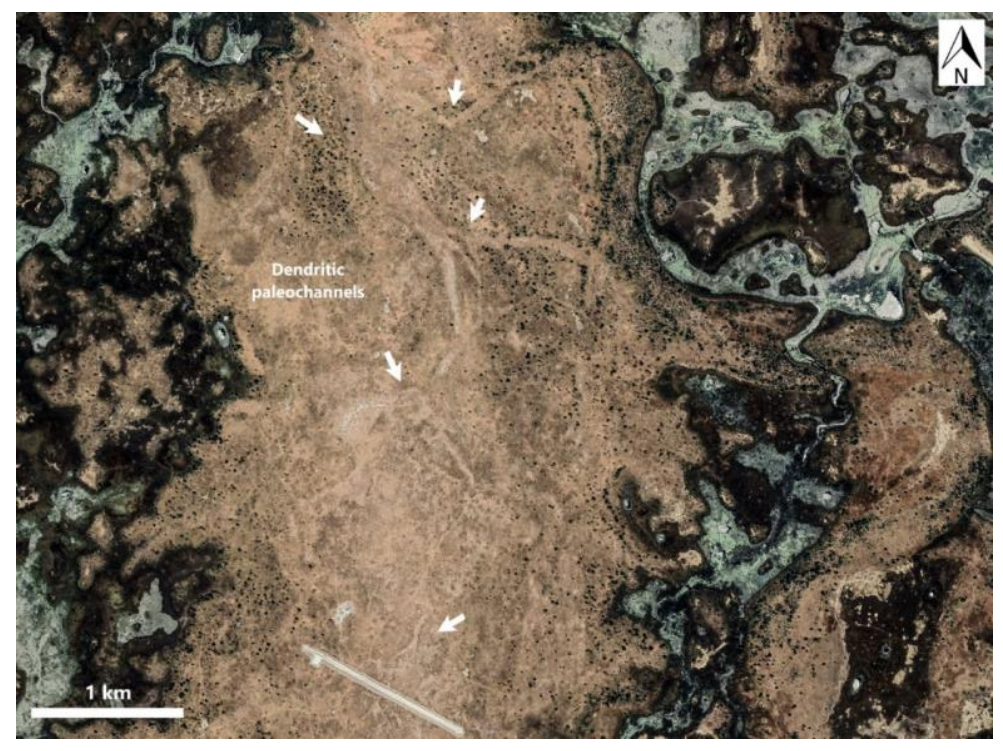

Fig. 8. Dendritic inverted channels in the Okavango Delta, Botswana, formed by burning and compaction of volumes of bank-forming peat $\left(19^{\circ} 27^{\prime} 9.33^{\prime \prime S}, 22^{\circ} 46^{\prime} 29.06 " \mathrm{E}\right.$; image credit: Google Earth). 


\section{2. Asia}

Thirteen sites of inverted fluvial channels have been reported to occur in Asia (see Table 2). An early investigation of inverted topographic features in Asia was carried out by Hörner (1932) in the Lop-Nor region; inverted channels at this site are associated with other erosional landforms such as yardangs. Teilhard de Chardin and Young (1935) identified sites in the Yangtze Valley, China, where the river was incised during the Early Cenozoic and filled by lava during the Early Pliocene. In the Kumtagh Desert, China, Wang et al. (2015) recently described gravel bodies that were deposited in the past $100 \mathrm{ka}$ (Fig. 9). In the Kumtagh Desert, some outcrops are characterized by large clasts and lack of cemented formations (Wang et al., 2015).

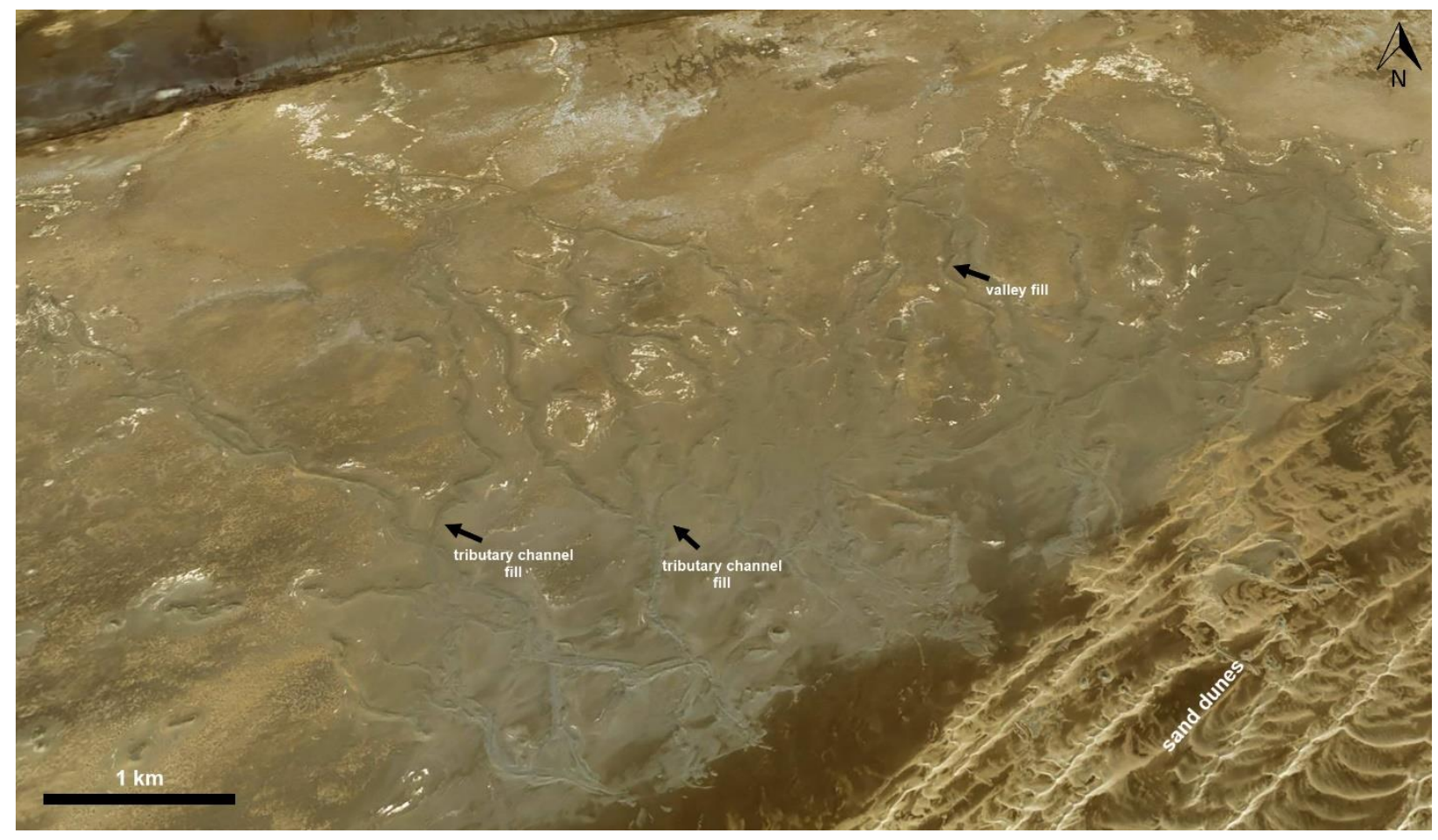

Fig. 9. Nadir view showing relics of fluvial drainage system in relief inversion in the Kumtagh Desert, China ( $40^{\circ} 5^{\prime} 25.00^{\prime \prime} \mathrm{N}, 91^{\circ} 32^{\prime} 12.25 " \mathrm{E}$; image credit: ESRI World Imagery).

In western and southern Asia, Miller (1937) described very distinctive networks of inverted channels in eastern Saudi Arabia (Fig. 10). These features occur over and area covering 10,000 $\mathrm{km}^{2}$ and are cemented by calcrete and silcrete (Miller, 1937). Wright (1958) identified some inverted stream features in the Syrian Desert; they were cemented by calcrete and ferricrte. More inverted channels were identified in Wadi Al-Batin, Wadi Ad Dwasir, and Wadi Sabha in Saudi 
Arabia (Holm, 1960; Matter et al., 2016) and the Negev Desert, Israel (Migon, 2004). Maizels $(1983,1987,1990)$ studied inverted river sediments in the Wadi Wahiba, Oman. She identified at least 12 successive generations of inversion and incision.

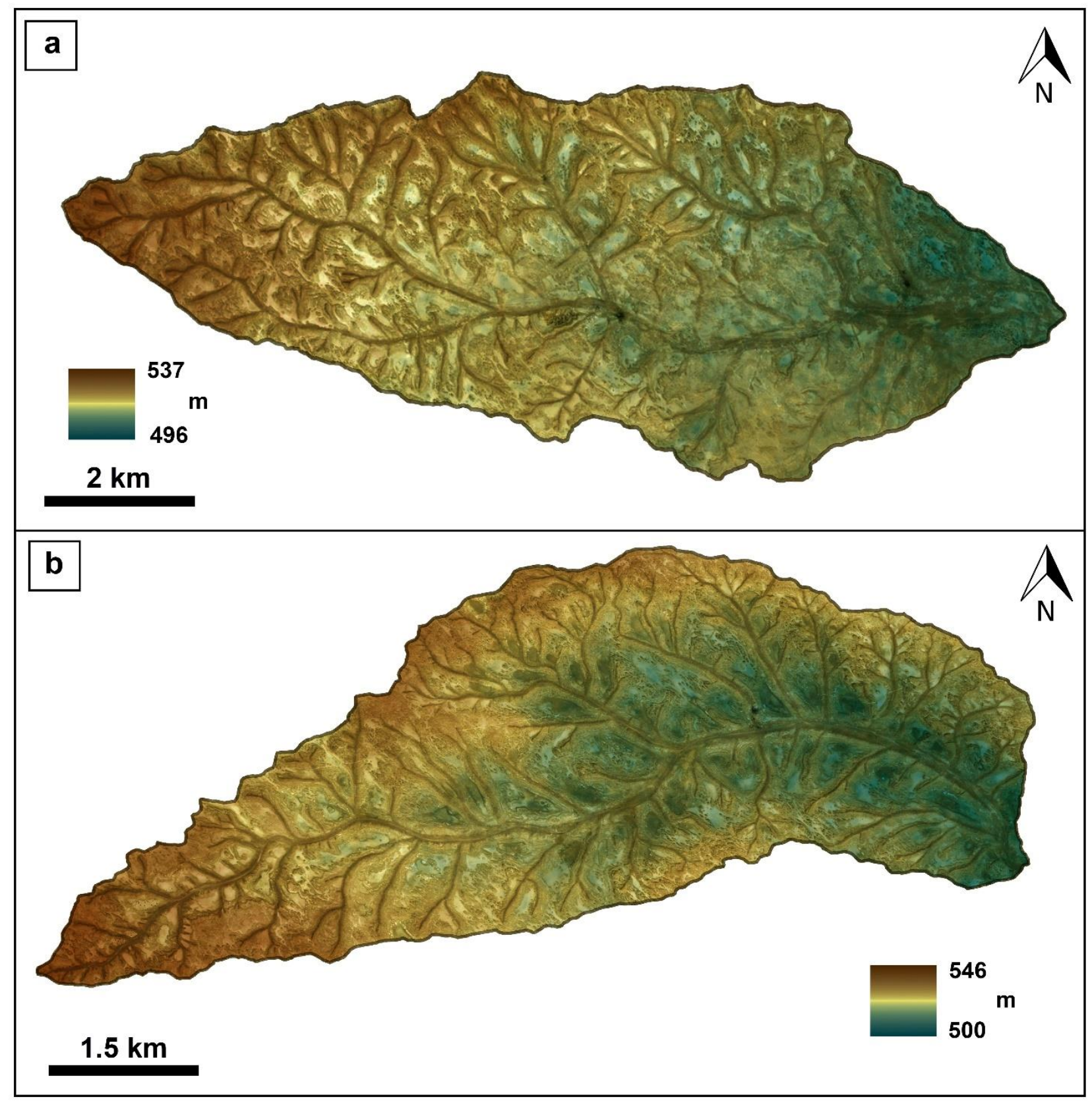

Fig. 10. ESRI World images coupled with ALOS PALSAR digital elevation models showing two well-preserved, inverted, dendritic paleostream systems in eastern Saudi Arabia; (a) $28^{\circ} 29^{\prime} 42.70^{\prime \prime} \mathrm{N}, 44^{\circ} 17^{\prime} 26.14^{\prime \prime E}$, and (b) $28^{\circ} 35^{\prime} 56.47^{\prime \prime} \mathrm{N}, 44^{\circ} 12^{\prime} 19.56^{\prime \prime} \mathrm{E}$. 
In India, Rakshit and Sundaram (1998) studied inverted channel and flood plain sediments cemented by calcrete and gypcrete. The crusts of calcrete and gypcrete on the surface and near surface indicate variations of the climate during late Quaternary time. Ollier and Scheth (2008) identified fluvial channel segments that were deposited from the late Cretaceous to the early Tertiary at the top of the Western Ghats escarpment, India. Additional examples in West Bengal are reported by Ghosh and Guchhait (2019), who investigated inverted channels that developed from ferricrete cementation during the late Pleistocene (150-35 ka).

\section{3. Australia}

Eleven examples of inverted channels have been reported in Australia (Table 2, Fig. 4). An ancient example in southwest Australia documents fluvial activity in the area since the Permian (Fairbridge and Finkl, 1978; Finkl and Fairbridge, 1979). Finkl and Fairbridge (1979) mapped four distinctive systems: a) the "Kirup system" which developed during the Permian; b) the "Westralian system," active during the Jurassic; c) the "Darling system," active from the Cretaceous to the Eocene; and d) the "Ravensthorpe system," an Eocene to Quaternary system. The Kirup system and Westralian systems were deeply buried and lithified at 300 and 280 m, respectively (Finkl and Fairbridge, 1979).

A distinctive paleochannel at Mirackina, South Australia, was investigated by Barnes and Pitt (1976), McNally and Wilson (1996), and Williams et al. (2013). This former channel is composed of a series of parallel mesas extending for more than $200 \mathrm{~km}$ from north to south that rise $30-40 \mathrm{~m}$ above the surrounding terrain (Fig. 11). The mesas consist of fluvial conglomerate and sandstone (McNally and Wilson, 1996). The sediments were cemented by silcrete and ferruginised silcrete in the surface and near subsurface environments before inversion began (McNally and Wilson, 1996). In the Kalgoorlie region, Western Australia, an Eocene system was incised into a weathered surface (Ollier et al., 1988). The main trunks of this system are several kilometers wide. The sediments were cemented by silcrete and ferricrete in the surface/near-subsurface setting before the onset of inversion (Ollier et al., 1988). Other examples have been reported to occur on the Cape York Peninsula, in the Lawlers area, in New South Wales, Queensland, and Robe River, Western Australia, and South Australia (e.g., Macleod, 1966; Mann and Horwitz 1979; Twidale et al., 1985; Hall and Kneeshaw, 1990; Anand and Smith, 1993; Pain and Ollier, 1995; Hou et al., 2007). 
In the El Capitan area, $\sim 50 \mathrm{~km}$ northeast of Cobar, Australia, there is an example of inverted relief capped by volcanic products (Cundari and Ollier, 1970). Mid-Miocene rivers were displaced from their beds by lava flows dated by K-Ar to be 17 million years old (McQueen et al., 2007; Cohen et al., 2007). These ridges stand up to $40 \mathrm{~m}$ above the surrounding topography; $25 \mathrm{~m}$ of this thickness consists of volcanic materials and $\sim 15 \mathrm{~m}$ is composed of Silurian sedimentary rocks (Cundari and Ollier, 1970). More volcanic examples are reported to occur in association with the Bullengarook, Campaspe, and Coliban rivers in Victoria (Pain and Ollier, 1995). Some of these examples have a complex history that includes incision by fluvial activity, lava flows, inversion by wind erosion, and post-basalt drainage response (Pain and Ollier, 1995).

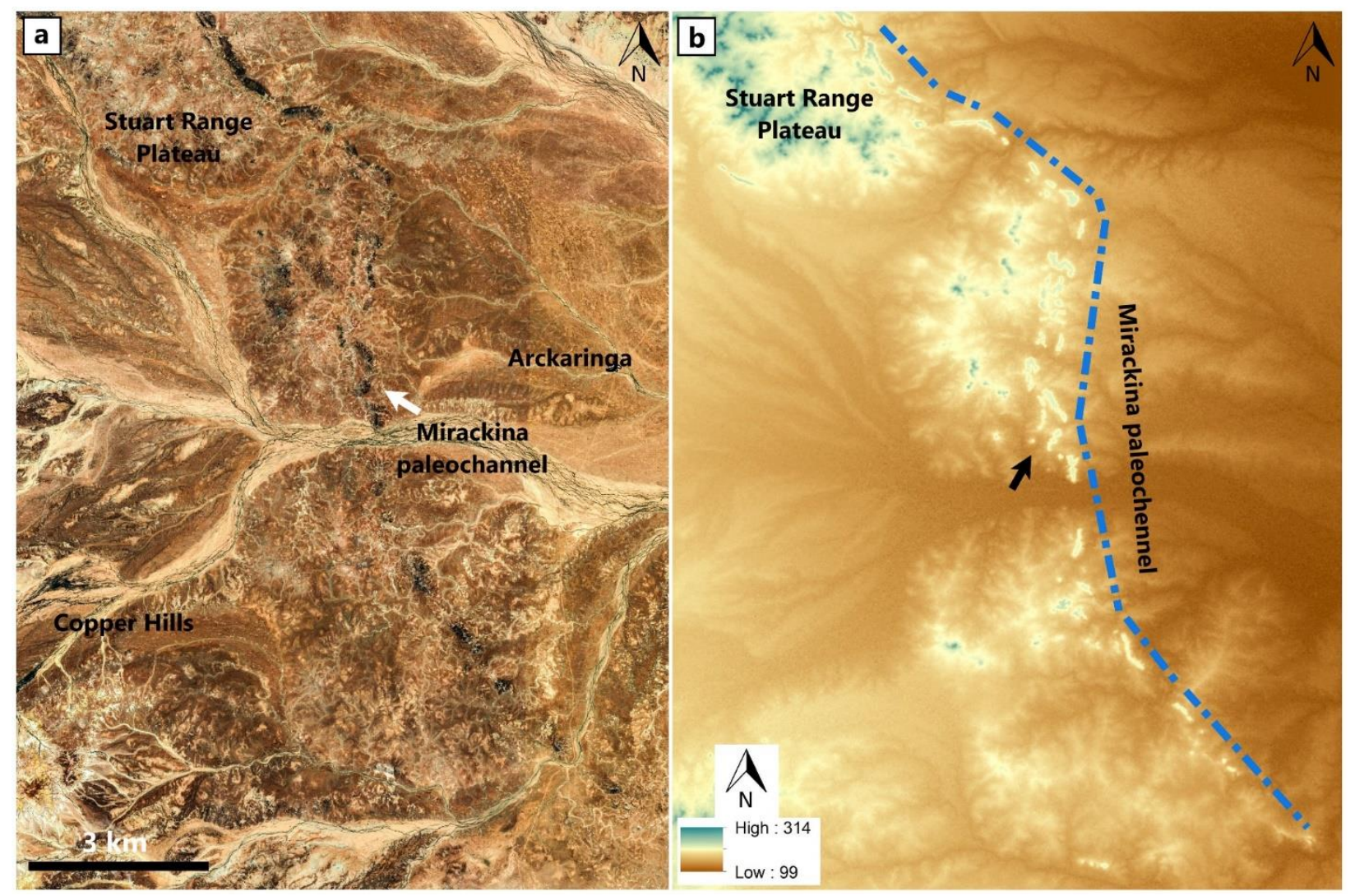

Fig. 11. (a) Google Earth image showing the Mirackina paleochannel and surrounded land surfaces (28 $\left.21^{\prime} 1.56^{\prime \prime S}, 134^{\circ} 49^{\prime} 14.52^{\prime \prime E}\right)$. (b) Digital Elevation Model (DEM) derived from the Shuttle Radar Topography Mission (SRTM) $30 \mathrm{~m}$ data depicting the topography of the same area.

\section{4. Europe}

Only two sites of channel relief inversion have been identified in Europe. These occur on the Isle of Skye in northwest Scotland (Bell and Williamson, 2013) and in the Ebro basin of Spain (Friend 
et al., 1983; Cuevas Martínez et al., 2010). On the Isle of Skye, near Talisker, Paleocene lavas have caused relief inversion of at least $120 \mathrm{~m}$ (Bell and Williamson, 2013). In the Ebro basin, an exhumed channel system covers an area of about 3,000 km² (Friend et al., 1981; Mohrig et al., 2000; Cuevas Martínez et al., 2010). These channel sandstones were deposited during OligoceneMiocene times and have a thickness up to $15 \mathrm{~m}$ in some outcrops (Cuevas Martínez et al., 2010) (Fig. 12).

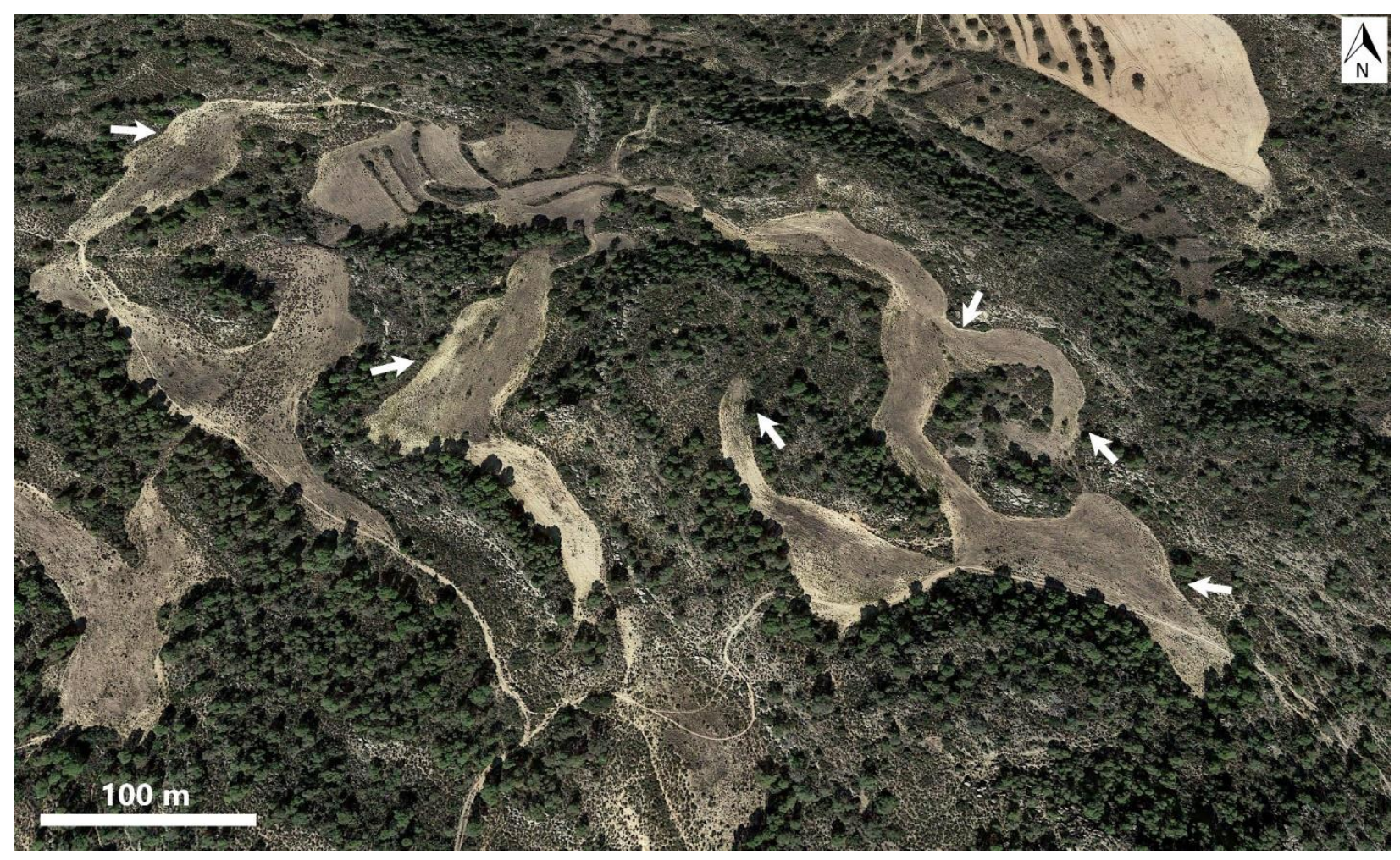

Fig. 12. Google Earth image depicting exhumed paleochannel outcrops in the Ebro basin that were deposited during the Oligocene and Miocene (41 $\left.{ }^{\circ} 8^{\prime} 55.03^{\prime \prime} \mathrm{N}, 0^{\circ} 11^{\prime} 7.31^{\prime \prime} \mathrm{W}\right)$.

\section{5. North America}

Inverted channels in North America have been reported to occur at 32 sites (Table 2; Fig. 4). Inverted channels in North America were first observed by Whitney (1865) in the Sierra Nevada; LeConte $(1880,1886)$ pointed out that these rivers were probably established at the beginning of the Cretaceous when this area was elevated above sea level to be a subject for fluvial activity during the Cretaceous and Tertiary. These rivers were then displaced by flooding of lava (LeConte, 1886). A typical example occurs at Table Mountain, California, where Rhodes $(1980,1987)$ 
identified at least 16 junctions along $\sim 15 \mathrm{~km}$ of the inverted paleochannel (Fig. 13). Gorny et al. (2009) used palaeomagnetic remanence data to determine the absolute age of the lave flow at $10.36 \pm 0.06$ and10.41 $\pm 0.08 \mathrm{Ma}$. More examples of inverted channels filled by volcanic materials in the USA have been identified on Mount Rainier, Washington (Lescinsky and Sisson, 1998), Lewis and Yakima Counties, Washington (Church et al., 1983), New Mexico (Channer et al., 2015), Cimarron County, Oklahoma (Suneson and Luza, 1999), on the Colorado Plateau (Lazear et al., 2013), Black Canyon, western Colorado (Sandoval, 2007), Snow Canyon State Park, Utah (Higgins, 2000), and the Grand Canyon, Arizona (Karlstorm et al., 2017). Inverted channels capped by lava are also well documented in Michoacán, Mexico (Guilbaud et al., 2011), Coconino County, Arizona (Billingsley et al., 2007), and St. George, Utah (Williams and Irwin, 2009).

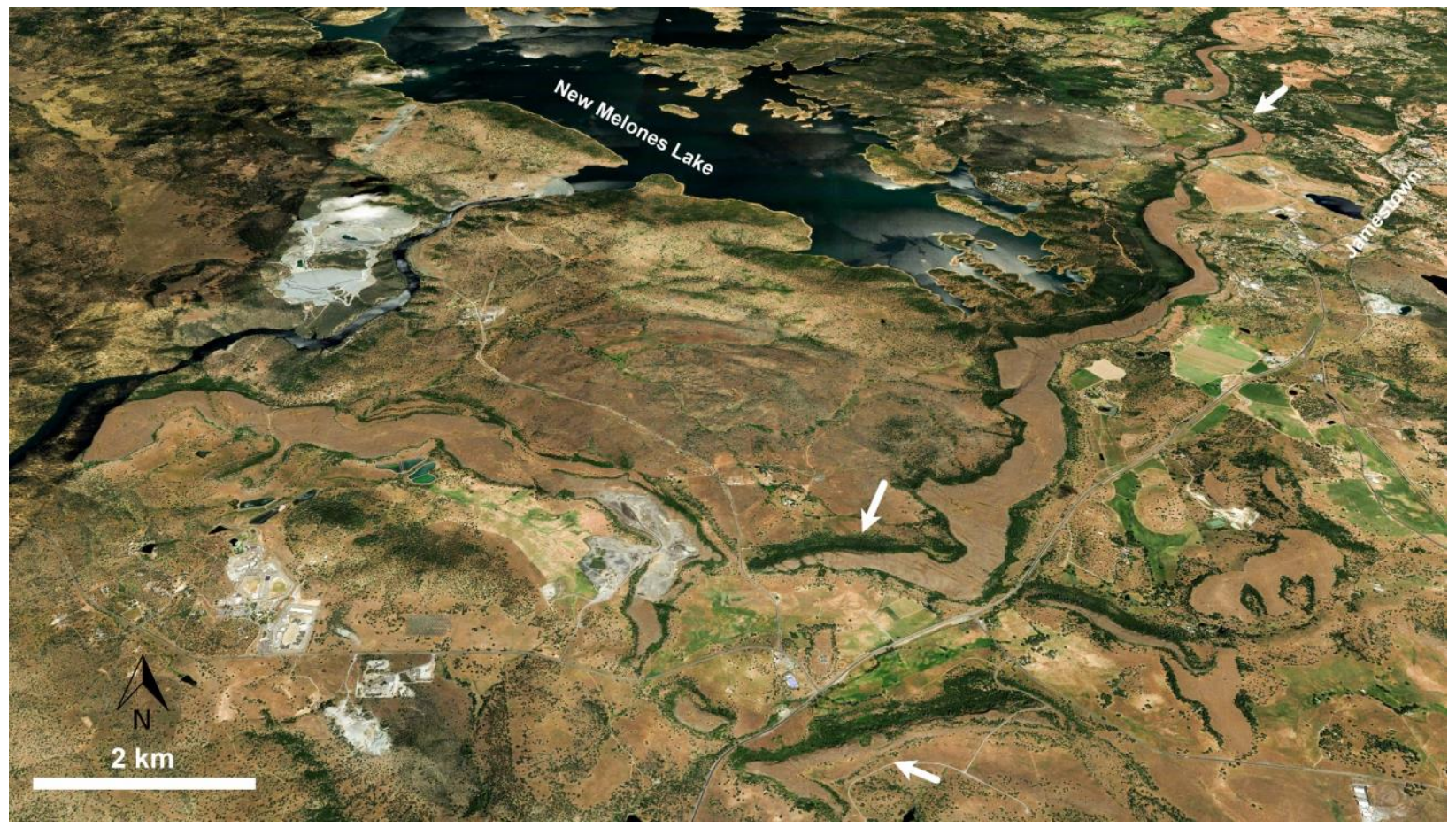

Fig. 13. Nadir view showing inverted channels capped by shsoshonite, basaltic, andesite, latite lava at Table Mountain, California (3755'14.33"N, 120²7'39.98"W; Image credit: Google Earth).

Lucchitta (2011) examined about $140 \mathrm{~km}$ of continuous and discontinuous inverted streams in northern Arizona. The pebbles of these streams came from the San Juan Mountains and were incised into Jurassic and Cretaceous rocks during the Miocene. Lucchitta (2011) pointed out that the drainage networks of this system were rearranged two times by recent rivers before the surrounded topography was lowered 1-2 km by erosion. Keller and Morgan (2013, 2016) examined 
an Eocene inverted fluvial system, which occurs over an area with $65 \mathrm{~km}$ in length and 4 to $10 \mathrm{~km}$ in width, in the east-central Colorado. This system may reach more than $40 \mathrm{~m}$ thickness with a paleoflow direction from east to northeast. These channel bodies extend to $12 \mathrm{~km}$ in length and between 1-2 km in width (Keller and Morgan, 2013, 2016). Love and Seager (1996) studied more than $300 \mathrm{~km}^{2}$ of well-preserved fluvial fans related to sediments of the Mimbres drainage, which were deposited during wet and dry periods in the late Pleistocene and Holocene. These fans are distinguished by anabranching distributary channels, some of which were cemented in the surface/near-subsurface environment and armoured by wind deflation (Fig. 14). These fans were deposited by large flood events during the extension of the Mimbres River (Love and Seager, 1996). More sites are characterized by cemented materials in surface and near-surface setting have been identified in Lake Tecopa, Nevada (Morrison and Mifflin, 2000), Harrisonburg, Virginia (Doctor et al., 2014), Quinn River, Nevada (Matsubara et al., 2015), Great Salt Lake, Utah (Oviatt et al., 2003), southeastern Arizona (e.g., Lindsey and Van Gosen, 2010), Colorado Piedmont (Morgan et al., 2008), and in the Mojave Desert, California (McDonald et al., 2003). Additional examples, in which there is absence or lack in cemented minerals in surface and near-surface setting coupled with large clasts, occur in northwestern Nebraska (Diffendal, 1994), Great Salt Lake (Oviatt et al., 2003), and eastern Montana/western North Dakota (Clausen, 2018).

Inverted point-bar sediments composed of very fine sandstones occur in the Clear Fork Group (Lower Permian) of the north-central Texas; these were deposited by small and variable discharge perennial streams of high sinuosity (Edwards et al., 1983). These point-bar sediments were buried, lithified, then exhumed (Edwaeds et al., 1983). Another exhumed paleochannel system has been studied in detail in southeast Emery County of east-central Utah (Derr, 1974; Higgins and Willies, 1995; Williams et al., 2007; Williams et al., 2009; Williams et al., 2011; Clarke and Stoker, 2011) (Fig. 1c). This system occurs within the Morrison and Cedar Mountain Formations, which were deposited during the late Jurassic and early Cretaceous, respectively (Williams et al., 2007). These paleochannels have carbonate cements and were buried beneath 2,400 m of younger deposits (Williams et al., 2007; Williams et al., 2011). These channels were buried for 75 million years until middle and late Cenozoic regional uplift led to their exhumation (Williams et al., 2007). Paleodischarge of these channels has been estimated to be from 8 to $120 \mathrm{~m}^{3} / \mathrm{s}$ (Derr, 1974). Mohrig et al. (2000) reported a more recent (Eocene) example from western Colorado, while Wang and 
Bhattacharya (2018) investigated paleochannels that were deposited in the Cretaceous Notom Delta in south central Utah.
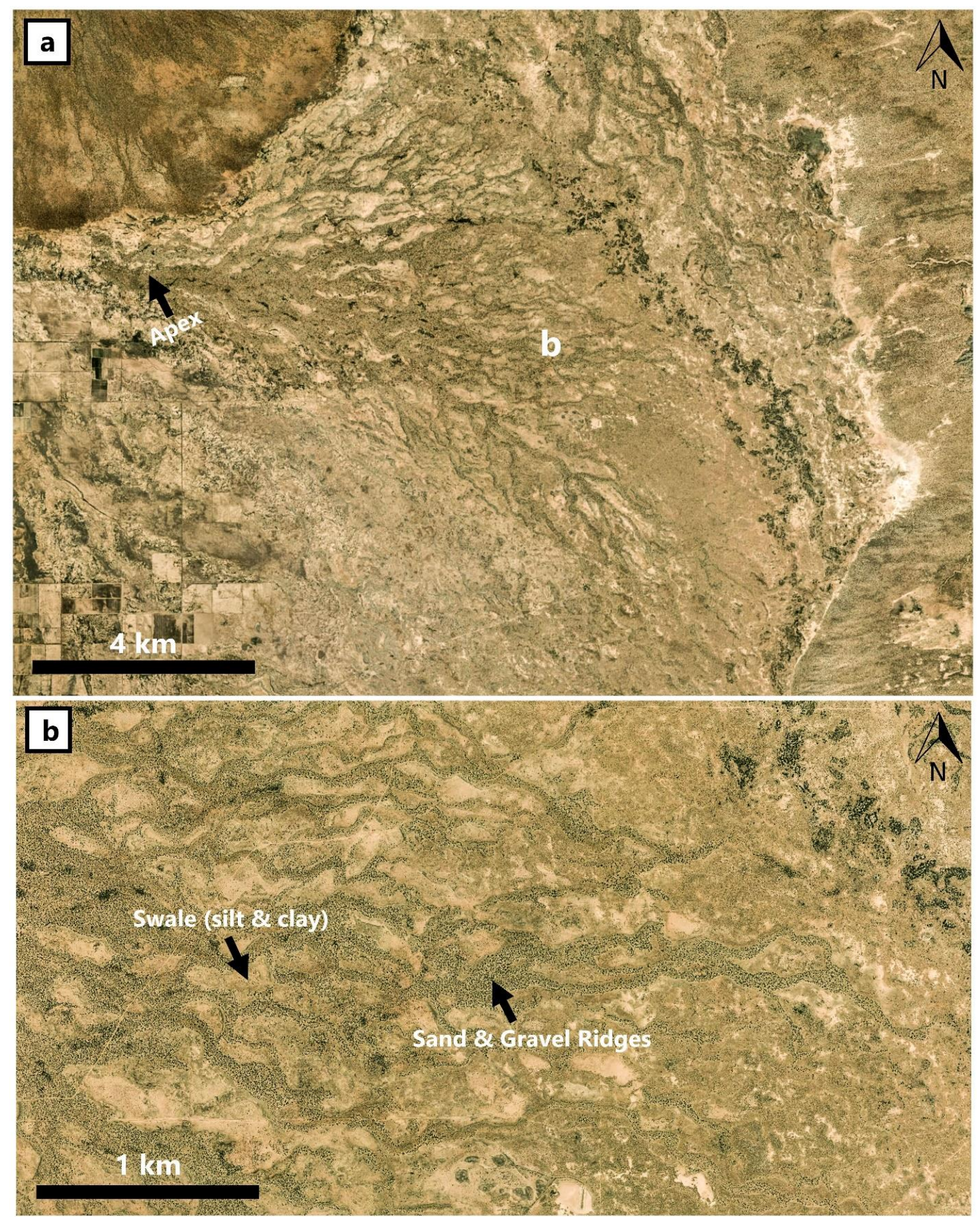

Fig. 14. (a) ESRI image showing an elevated fluvial fan (Columbus fan) in the Mimbres Basin, New Mexico (31 $\left.55^{\prime} 16.18^{\prime \prime N}, 107^{\circ} 28^{\prime} 56.62^{\prime W}\right)$. (b) Close-up satellite image for the Mimbres Basin showing complex system of anabranching and meandering forms with a distributary pattern (Image Credit: ESRI World Imagery). 


\section{6. Mediterranean Sea}

Recently, inverted paleoriver features were identified offshore of Cyprus, Syria, Lebanon, and Israel (Fig. 15; Madof et al., 2019). These submarine ridges were discovered in seismic data from the western Levant Basin with a total length $\sim 500 \mathrm{~km}$ (Madof et al., 2019). These former rivers are interpreted to have deposited sediments that became inverted during the late Miocene Messinian Salinity Crisis when the level of the Mediterranean was considerably lower than it is at present (Madof et al., 2019). These stream channels were cemented, eroded to stand as ridges, then buried beneath younger geological formations.

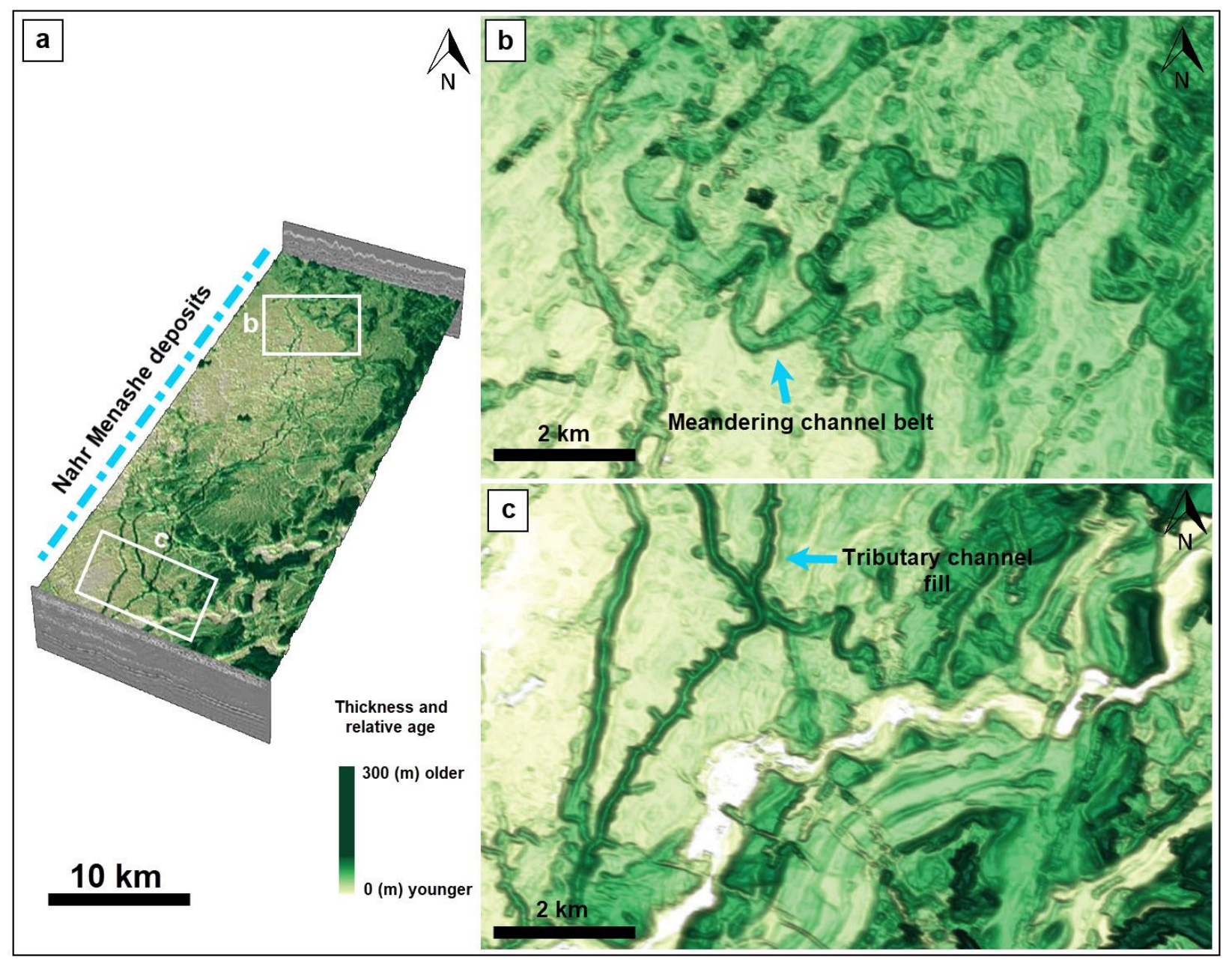

Fig. 15. (a), (b), (c) Isochron maps obtained 3D seismic data show the morphology of Nahr Menashe paleoriver that incised and inverted during the Messinian Salinity Crisis $\left(34^{\circ} \mathrm{N}, 35^{\circ} \mathrm{E}\right.$; adapted from Madof et al., 2019, https://insu.cnrs.fr/fr/cnrsinfo/quand-des-fleuves-secoulaient-aufond-de-la-mediterranee). 


\section{7. South America}

In Argentina, there are three documented sites of inverted relief (Cas et al., 2011; Foix et al., 2012; Ristorcelli et al., 2013; Foix et al., 2018). Two of the three sites were capped by volcanic materials in Cerro Galán Ignimbrite (Cas et al., 2011) and Pinguino, Santa Cruz Province (Ristorcelli et al., 2013). The third site is in Cañadón Asfalto Basin, and this consists of sandstone bodies deposited during Cretaceous time, then buried, lithified and exhumed (Fig. 16; Foix et al., 2012; Foix et al., 2018). The exhumed outcrops cover area of $\sim 100 \mathrm{~km}^{2}$ (Foix et al., 2012).

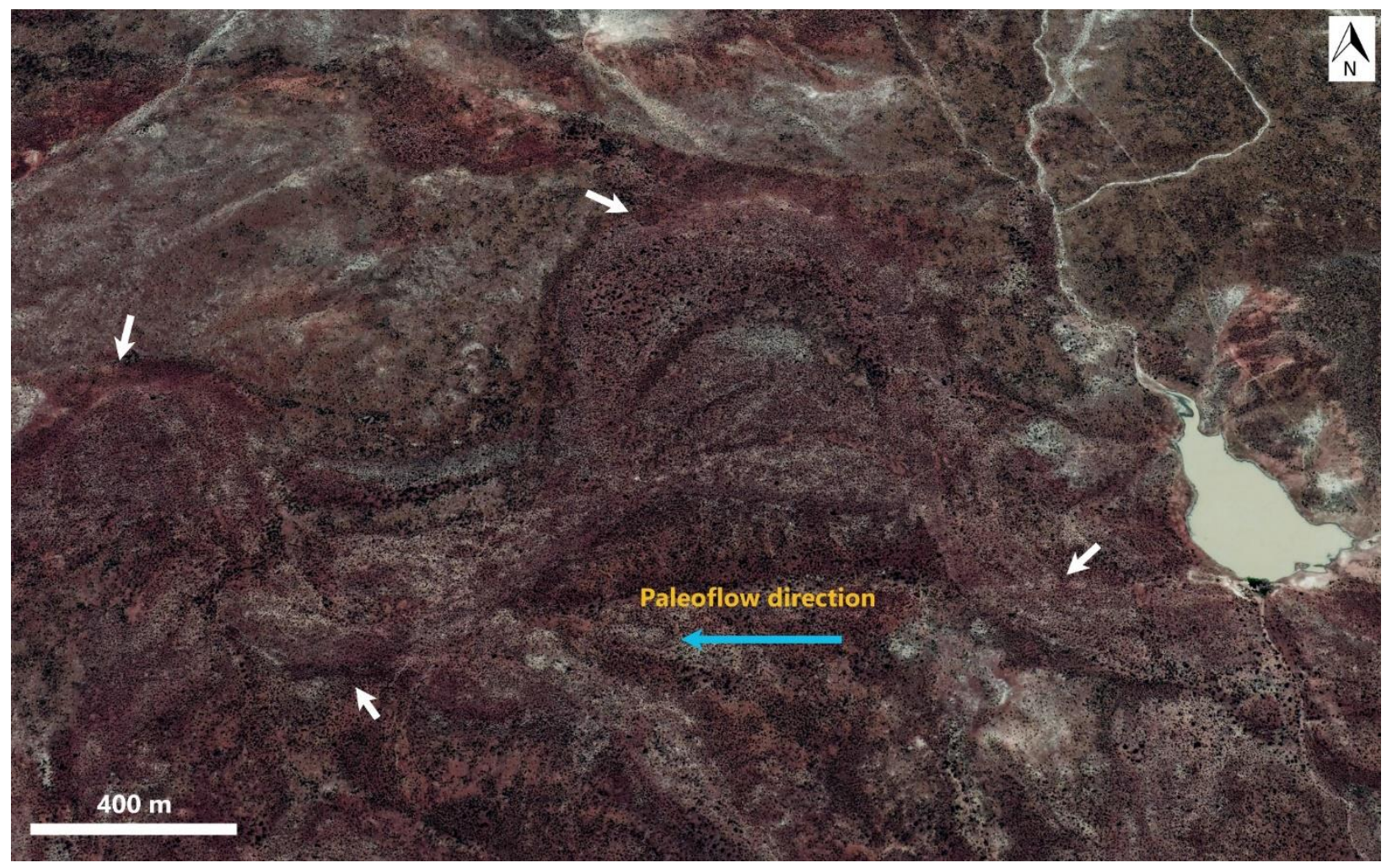

Fig. 16. Google Earth image showing meandering paleochannel with high-sinuosity pattern in Cañadón Asfalto Basin, Argentina (44 4'7.33"S, 6744'25.75"W).

Two sites of relief inversion that filled by lava flows have been identified in Colombia in Nevado del Tolima and Cerro Machin (Thouret et al., 1995) and the Frío River valley (Caballero et al., 2016). Morgan et al. (2014) identified some inverted channels associated with alluvial fans in the Pampa del Tamarugal region of the Chilean Atacama Desert, which they identified as a terrestrial analogue for similar sinuous ridges in Saheki crater on Mars. These channels are in 1-2 $\mathrm{m}$ in height, and they are inactive parts of alluvial fans (Morgan et al., 2014). These paleochannels were inverted due to coarse grains and potential chemical cementation in surface and neaar-surface 
setting (Morgan et al., 2014). Very young inverted channels and canals ( $1 \mathrm{ka}$ in age) have been reported from Lower Ica Valley, Peru, that are consolidated by calcrete enrichment (BeresfordJones et al. 2009).

\section{Processes of ReLIEF INVERSION}

Our survey suggests that five different pathways lead to fluvial channel inversion on Earth. Fluvial sediments can become cemented in the surface and near-subusurface environment (early diagenesis), or they can be compacted and cemented in the deep sub-surface (i.e. burial diagenesis). Alternatively, channels can be filled or partly filled by volcanic materials. Some channels are inverted without cementation or igneous cap rocks; these include channel sediment bodies covered in a lag or armour of their own coarse clasts and the burning and compaction of bank-forming peat.

We find that $\sim 59 \%$ of the examples on Earth appear to have been cemented in surface/nearsubsurface environments prior to inversion, $\sim 23 \%$ were channels or valleys filled or partly-filled by volcanic materials (lava, tuff), $\sim 11 \%$ are cases in which channel sediments were lithified via deep burial diagenesis, 6\% examples formed by surface armour development on unconsolidated fluvial sediment, and $\sim 1 \%$ (one example) resulted from the burning and compaction of bankforming peat. Wind deflation, exhumation due to tectonic activity, and water erosion played important roles in removing the central parts of the channel leaving the floor stands as a ridge. In this section, we describe the mechanisms that transform the channel from an incision to a ridge (an inversion) in the landscape.

\section{1. Circumstances LeAding to CHANNEL FiLl EROSION RESistanCE}

\section{1. 1. Fluvial sediment cementation during near-surface early diagenesis (eogenesis)}

Surface and near surface cementation and relief inversion typically leads to linear, sometimes discontinuous, and usually sinuous single or double ridges that provide evidence for paleochannels (Fig. 17a). Cementation is limited to perhaps tens of meters, and no deep burial is involved. In terms of coarse clastic sediment diagenesis, the regime of this process is "eogenesis" (Worden and Burley, 2003). A common term for these materials is duricrusts, "regolith material indurated by a cement or the cement only, occurring at or near the surface, or as a layer in the upper part of the regolith" (Eggleton 2001). Duricrusts play a role in relief inversion because of the tendency for some to form preferentially in valleys and depressions (Pain and Ollier, 1995; Pain et al., 2007). 
Cementation by silica, iron, calcium carbonate, or gypsum, among others, form ferricrete, silcrete, calcrete, and gypcrete, respectively (Pain and Ollier, 1995; Wright, 2007; Nash and Ullyott, 2007; Worden and Burley, 2003). Differing cements can be co-mingled (e.g., silcrete and calcrete - Nash and Shaw, 1998). Duricrusts have generated a vast literature; only those aspects relevant to relief inversion are considered here.

Silcrete is "strongly silicified, indurated regolith, generally of low permeability, commonly having a conchoidal fracture with a vitreous lustre" (Eggleton, 2001). Most silcretes form low in landscapes along valleys or lakes but some may form at breakaway margins as a result of lateral groundwater movement (Taylor and Eggleton, 2017). It is thought that silcretes form in wet and probably seasonal climates where water tables are high for at least part of the year. Taylor and Eggleton (2017) also suggest that there must be plenty of organic acids.

Ferricrete is "an indurated material formed by the cementation of regolith by iron oxyhydroxides, mainly goethite and/or hematite" (Eggleton 2001). It may form in both in situ weathered bedrock and in sediments. It commonly forms in low-lying areas such as lakes, swamps, spring discharge sites (seepages), valley floors, aquifers or groundwater-mixing zones (Anand and Paine 2002). It seems likely that iron moves in solution to lower parts of the landscape during wet periods and dries out and becomes indurated during dry periods. This implies seasonal climates and fluctuating water tables (Pain and Ollier 1992).

Calcrete is a term "used broadly to refer to regolith carbonate accumulations, forming more- or less-well cemented aggregates composed largely of calcium carbonate" (Eggleton 2001). Calcrete occurs mainly in arid and semiarid regions where the lack of leaching by rainfall leads to accumulation of carbonates. Groundwater calcretes are of most interest here because they can lead to relief inversion when they are deposited along valley floors (Pain and Ollier, 1995).

This process can occur in two settings relative to the surface; surficial cementation like those in the southern part of the Egyptian Sahara (e.g., Giegengack, 1968; Zaki et al., 2018), in the Mimbres drainage in New Mexico (Bryan, 1940; Love and Seager, 1996), in the Kumtagh Desert, China (Wang et al., 2017), and near surface cementation like examples in Australia at Mirackina (Barnes and Pitt, 1976; Pain and Ollier, 1995; McNally and Wilson, 1996) and in Wadi Wahiba in Oman (Maizels, 1983, 1987, 1990). Surface and near surface cementation occurs from evapotranspiration of water from near-surface environments (Pain and Ollier, 1995; Wright, 2007; Nash and Ullyott, 
2007). Groundwater discharge was the main cause of inversion of relief in the Arckaringa, South Australia, where fill remnants are preserved beneath a layer of silcrete (McNally and Wilson, 1996). Some inverted river valleys and channels on Cape York Peninsula in Queensland, Australia, were created as a consequence of the formation of silcrete in alluvium and in saprolite adjacent to the alluvium (Pain et al. 1994).

The occurrence of inverted channels in surface and near-surface settings require low-precipitation rates and high-evaporation rates and thus are common in the arid environments (e.g., Goudie, 1973; Dixon and McLaren, 2009). One thing that all these duricrusts have in common is the requirement for water to transport the cementing agent. Lateral water movement both downslope and down valley is important.

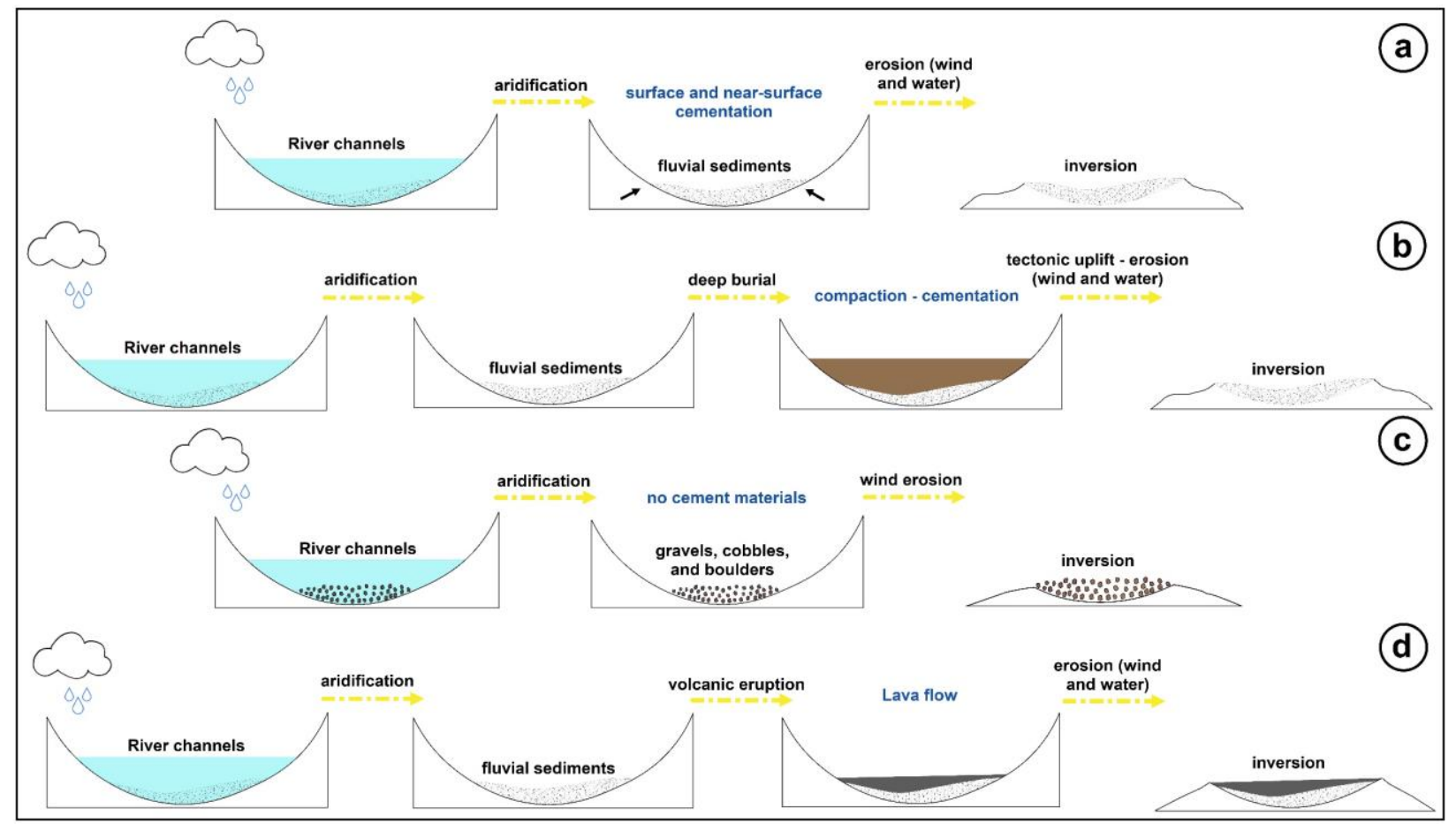

Fig. 17. Schematic diagram showing inversion of relief mechanisms; (a) fluvial sediment cementation during near-surface early diagenesis (eogenesis), (b) fluvial sediment or channel fill lithification during burial diagenesis in the subsurface (mesogenesis), (c) ) channel sediment body surface armouring, and (d) channel or valley filling by volcanic materials. 


\section{1. 2. Fluvial sediment or channel fill lithification during burial diagenesis in the subsurface (mesogenesis)}

Consolidation of fluvial sediment, usually on alluvial fans, deltas or alluvial plains, occurs when the sediments become buried to depths of at least $1 \mathrm{~km}$ (Fig. 17b). The mesogenesis regime starts at depths of $1-2 \mathrm{~km}$, where the temperatures reach $30-70^{\circ} \mathrm{C}$ (Worden and Burley, 2003). Burial diagenesis can occur purely via compaction but usually involves both compaction and cementation. Some cementation and replacement in the sediments is involved due to temperature and pressure (e.g., Taylor, 1950; Worden and Burley, 2003). Subsequent tectonic events and exhumation can return lithified channel sediments to the surface and differential erosion can invert

these rocks (e.g., Williams et al., 2007; Zaki et al., 2018). The examples in Utah studied by Williams et al. (2007) were buried to 2,400 m beneath the surface; other deep-burial examples occur in the Egyptian Sahara (Brookes, 2003; Zaki et al., 2018), the Algerian and Libyan deserts (Girard et al., 2012), Argentina (Foix et al., 2012; Foix et al., 2018), and in Spain (Cuevas Martínez et al., 2010).

The materials involved in deep burial lithification and exhumation are typically older than those related to surface/near-subsurface cementation (Section 4.1.1), and, although the inverted ridges may occur as singular ridges or coaligned ridge segments, exhumed examples can also display cross-cutting patterns of former channels of differing age. Because of their origin on fans and plains, they can be spread over large areas; the example in Spain (Cuevas Martínez et al., 2010) covers an area of $30 \times 30 \mathrm{~km}^{2}$.

\section{1. 3. Channel or valley filling by volcanic materials}

Stream channels, and sometimes the valleys in which they occur, can become topographically inverted via differential erosion some time after volcanic materials flow down a stream course, mimicking its form (Fig. 17d; LeConte, 1880, 1886; Cundari and Ollier, 1970; Pain and Ollier, 1995). In these cases, the solidified lava or tuff is resistant to erosion and protects the underlying valley floor sediments and regolith from erosion, leading eventually to inverted relief (Pain and Ollier, 1995). Well-preserved examples occur in Sierra Nevada, California, USA (e.g., Whitney, 1865; LeConte, 1880; 1886; Rhodes, 1980, 1987) and El Capitan, northeast of Cobar, NSW, Australia (Cundari and Ollier, 1970; McQueen et al., 2007). Other examples are found in Victoria, Australia, where basalts overlie gold-bearing alluvium. The latter is cemented to form silcrete in 
some places, the silcrete being restricted to the edges of the former channels (Pain and Ollier, 1995).

\section{1. 3. Channel sediment body surface armouring}

In arid or hyperarid settings, unconsolidated fluvial sediment can take on an inverted (ridge) form entirely by aeolian deflation in which finer sediment is removed and a lag of coarser grains (pebbles, cobbles, in some cases, boulders) armours the surface of the remaining, underlying deposit (Fig. 17c; Pain and Ollier, 1995; Giegengack, 1968; Zaki et al., 2018). This process is rare because it requires both an absence of or minimal cementation and processes (particularly aeolian deflation) to concentrate clasts that form the armor (e.g., Giegengack, 1968; Pain and Ollier, 1995). Reported examples occur in the Mimbres drainage, New Mexico, USA (Bryan, 1940; Love and Seager, 1996), Egyptian Sahara (Giegengack, 1968; Zaki et al., 2018), and the Kumtagh Desert, China (Wang et al., 2017).

\section{1. 5. Compaction of bank-forming peat}

Stream sediment can be left standing as a ridge when the peat that forms stream banks loses volume due to burning and compaction. This process has been reported from only one site in the Okavango Delta (Fig. 8; Ellery et al., 1989; Gumbricht et al., 2004).

\section{2. EROSIONAL INVERSION OF CHANNELS}

A channel becomes inverted when material formed by one of the processes described above resists erosion at the Earth's surface to a greater degree than the surrounding material. Several processes act to promote this erosion, including surface runoff, wind erosion, and tectonism.

\section{2. 1. Water erosion}

In regions where fluvial processes dominate, the main agent of relief inversion is running water, usually in channels. In humid areas such as Victoria, Australia, and parts of California, the resistant material is mainly lava, although silcrete is also common. In these places, water flows on either

side of the resistant rock, forming twin lateral streams that eventually cut down and leave the lava and underlying alluvium as inverted relief. 
In drier or more seasonal climates, water is also dominant in surface-lowering and relief inversion. In areas such as the Cape York Peninsula, Australia, the dominant agent of denudation, or surface lowering, is water either flowing across the landscape as surface wash or confined in channels as streams and rivers. Water thus contributes to the development of inverted channels, forming new drainage lines or networks (Pain et al., 1994). Duricrusts such as ferricrete and silcrete protect former valley floors from erosion, leading to inverted relief with both duricrusts and alluvium occupying high areas in the landscape. Duricrusts continue to form in the new valleys (Fig. 18). Several cycles of relief inversion during surface lowering may explain the widespread scatter of well-rounded quartz pebbles in Cape York, Australia.

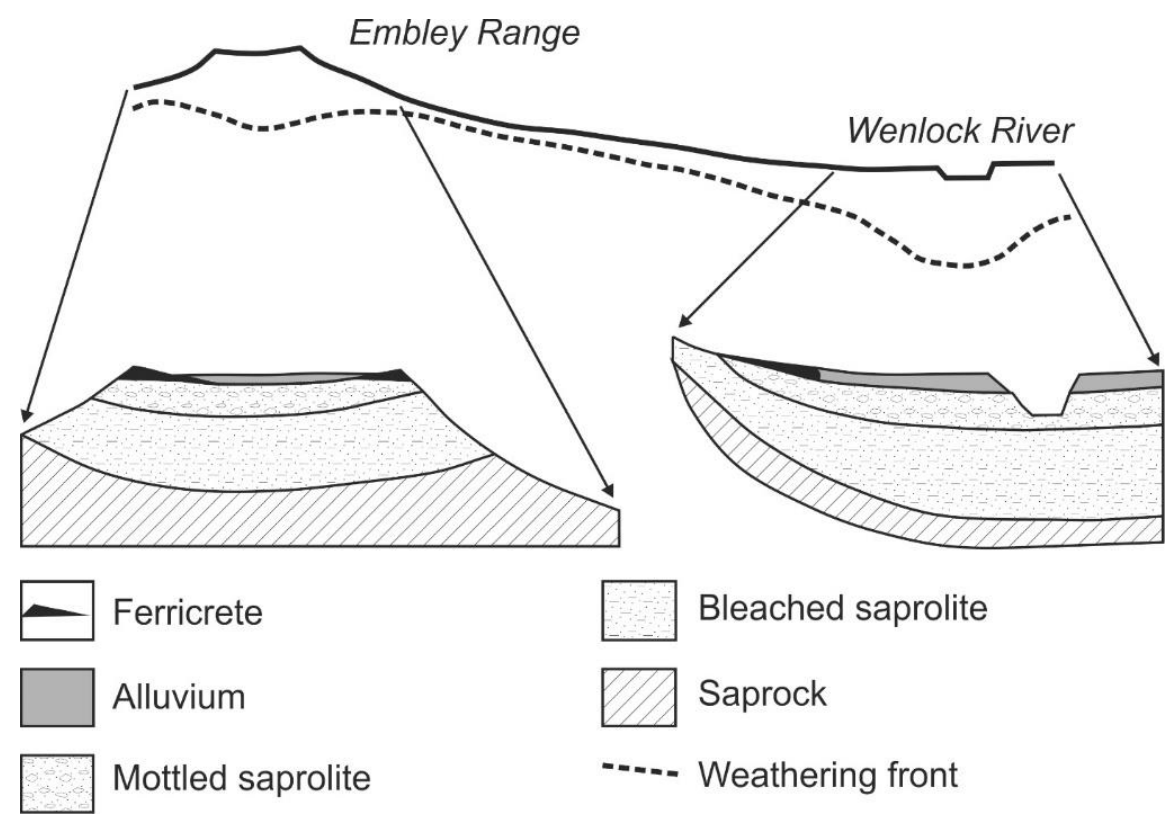

Fig. 18. Inverted relief on Cape York Peninsula, northern Australia. On the Embley Range $\left(12^{\circ} 46^{\prime} 16.26^{\prime \prime} \mathrm{S}, 142^{\circ} 39^{\prime} 46.66^{\prime \prime} \mathrm{E}\right)$ there is a deep weathering profile capped by alluvium and ferricrete in inverted relief. There is a very similar profile on the modern Wenlock River, the location of a future inversion of relief. Not shown are pods of silcrete in the mottled saprolite that may contribute to the resistant materials that led to inverted relief.

There are many other examples, where water erosion contributes to relief inversion, including west Esna City in the Egyptian Sahara (Fig. 19; Zaki et al., 2018) and Wadi Wahiba in Oman (Maizels, 1983, 1987, 1990). Surface runoff could also be accompanied by groundwater discharge along inverted channels such as at Mirackina, South Australia (Barnes and Pitt, 1976; McNally and Wilson, 1996). We find that relief inversion by water erosion requires a change in base level, either 
abrupt or gradual, to maintain the gradients necessary for water flow (Barned and Pitt, 1976; Pain et al., 1994; Zaki et al., 2018).

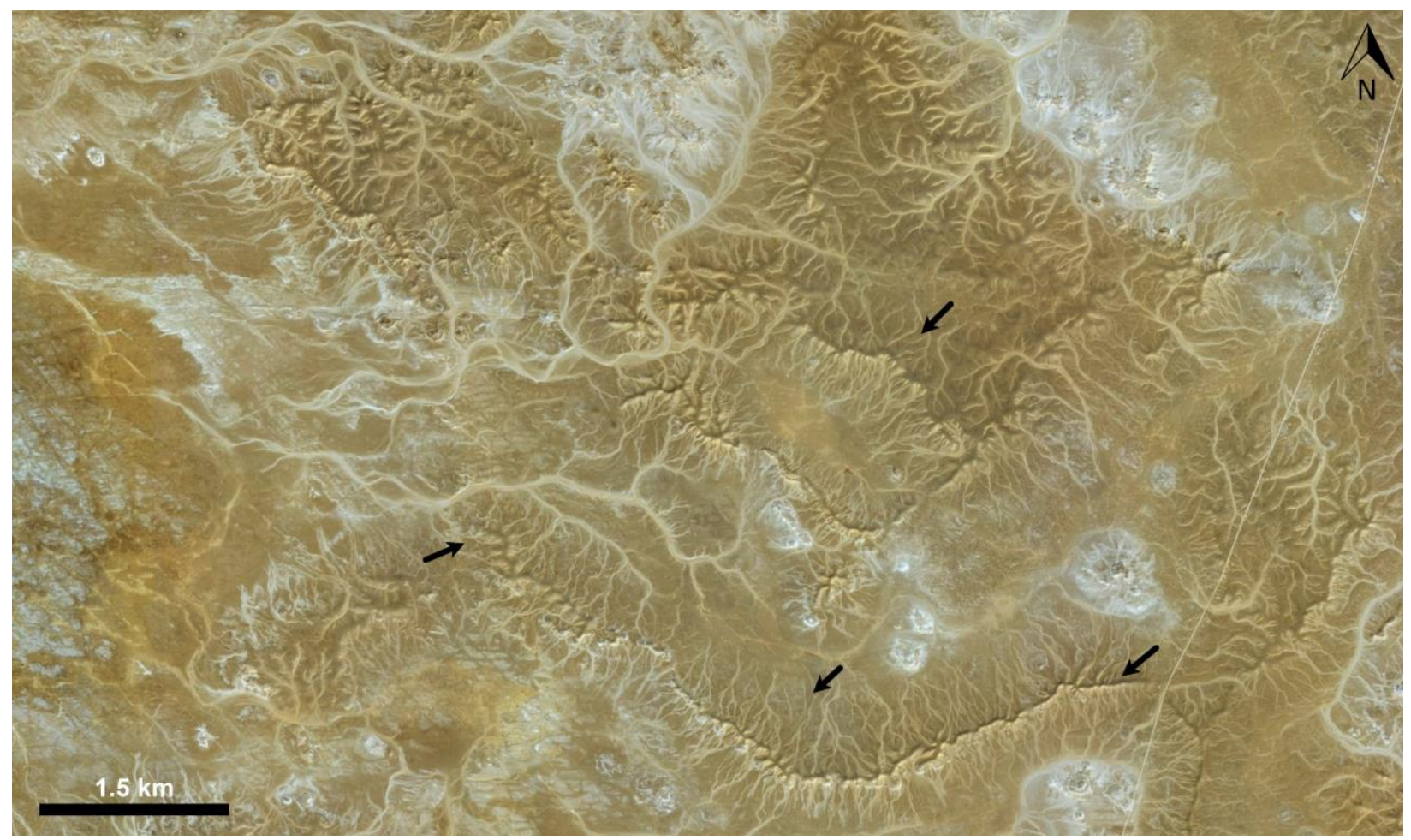

Fig. 19. Inverted channels are surrounded by modern drainage lines in west Esna City, Egypt $\left(25^{\circ}\right.$ 09' 56.4"N, $31^{\circ} 59$ '27.9"E; Image credit: ESRI World Imagery). The modern drainage lines contribute to relief inversion process.

\section{2. 2. Aeolian erosion}

There are two main processes of wind erosion: abrasion and deflation (e.g., Wiggs and Livingstone, 2003). Abrasion is a result of the impact of solid particles driven by saltation (e.g., Wiggs and Livingstone, 2003; Gillies et al., 2009; Bristow et al., 2009). Deflation is the entrainment and removal of solid particles by wind. This happens through saltation of coarser particles and suspension of fine particles. On Earth, in arid and hyper-arid settings, deflation can take place down to the level of the water table. However, unlike relief inversion by water erosion, wind erosion does not require a fall in base level; it can indeed form closed depressions (Giegengack, 1968; Pain and Ollier, 1995).

Aeolian erosion is involved in the development of inverted relief in arid climates on Earth, where wind, at least today, is the dominant geomorphic process in hyper-arid and arid environments. There are examples in the Sahara (e.g., Giegengack, 1968 ; Bristow et al., 2009; Zaki et al., 2018), 
Kumtagh Desert, China (Wang et al., 2017), Arabian Peninsula (e.g., Matter et al., 2016), North America (e.g., Love and Seager, 1996; Oviatt et al., 2003), and South America (e.g., BeresfordJones et al. 2009; Morgan et al., 2014). The rate of erosion of materials in "the dustiest place on Earth," the Bodélé Depression, Chad, ranges from 1.6 to $10 \mathrm{~mm}$ per year (Bristow et al., 2009). This rate has produced one of the youngest inverted channels on Earth during the last 2,400 years (Bristow et al., 2009). A rate of 0.21-0.28 mm/year in the Kumtagh Desert, China, produced an inverted channel with an age of $100 \mathrm{ka}$ (e.g., Lai et al., 2014; Wang et al., 2017).

\section{2. 3. Exhumation}

Tectonic events also are involved in the development of inverted channels (Williams et al., 2007). When a stream sediment becomes deeply buried and lithified, tectonic events can return the fluvial sediments to the surface to become the subject of wind erosion and surface runoff, which can lead to topographic inversion. Exhumation by tectonic activity has been reported from Utah (Williams et al., 2007; Williams et al., 2011), Ebro basin (Cuevas et al., 2010), Cañadón Asfalto Basin, Argentina (Foix et al., 2012; Foix et al., 2018), South West Australia (Fairbridge and Fink1, 1978), Tassili N'Ajjer, Libya and Algeria (Girard et al., 2012), and Northern Niger (Smith et al., 2015).

\section{MORHPHOLOGY, SEDIMENTOLOGY, AND GEOCHRONOLOGY}

\section{1. Morphology}

Inverted fluvial landforms on Earth usually occur in the form of flat-topped linear sinuous channels, deltas and fans, meanders and point bars (Fig. 20). Sinuous channel forms are the most common. The preserved length of stream channel segments ranges from tens of meters like those in the Egyptian and Sudanese Sahara (Zaki and Giegengack, 2016; Giegengack and Zaki, 2017; Zaki et al., 2018) to tens of kilometers such as examples in northern Arizona (Lucchitta et al., 2011), west of Ghard Abu Muharik, Egyptian Sahara (Zaki et al., 2018), Wahiba, Oman (Maizels, 1990), Table Mountain, California (Rhodes, 1987), and Arckaringa in South Australia (Barnes and Pitt, 1976; McNally and Wilson, 1996). These inverted channels have widths ranging from a few tens of meters like those in eastern Saudi Arabia and New Mexico to hundreds of meters such as the inverted channels on the surface of Limestone Plateau in Egypt and in Wahiba, Oman (e.g., Miller, 1937; Maizels, 1987; Love and Seager, 1996; Zaki et al., 2018). Inverted channels typically have heights of tens of meters: examples are $33 \mathrm{~m}$ on the surface of Limestone Plateau in the 
Egyptian Sahara, and 30-40 m in South Australia (e.g., McNally and Wilson, 1996; Zaki et al., 2018). These fluvial ridges exhibit different patterns, including linear, dendritic, and rectangular, but a sinuous pattern is the most common. All of these inverted channels were incised by precipitation-fed runoff except one example in the Lake Bogoria, Kenya, that incised by groundwater seepage from springs (Renault et al., 2013).

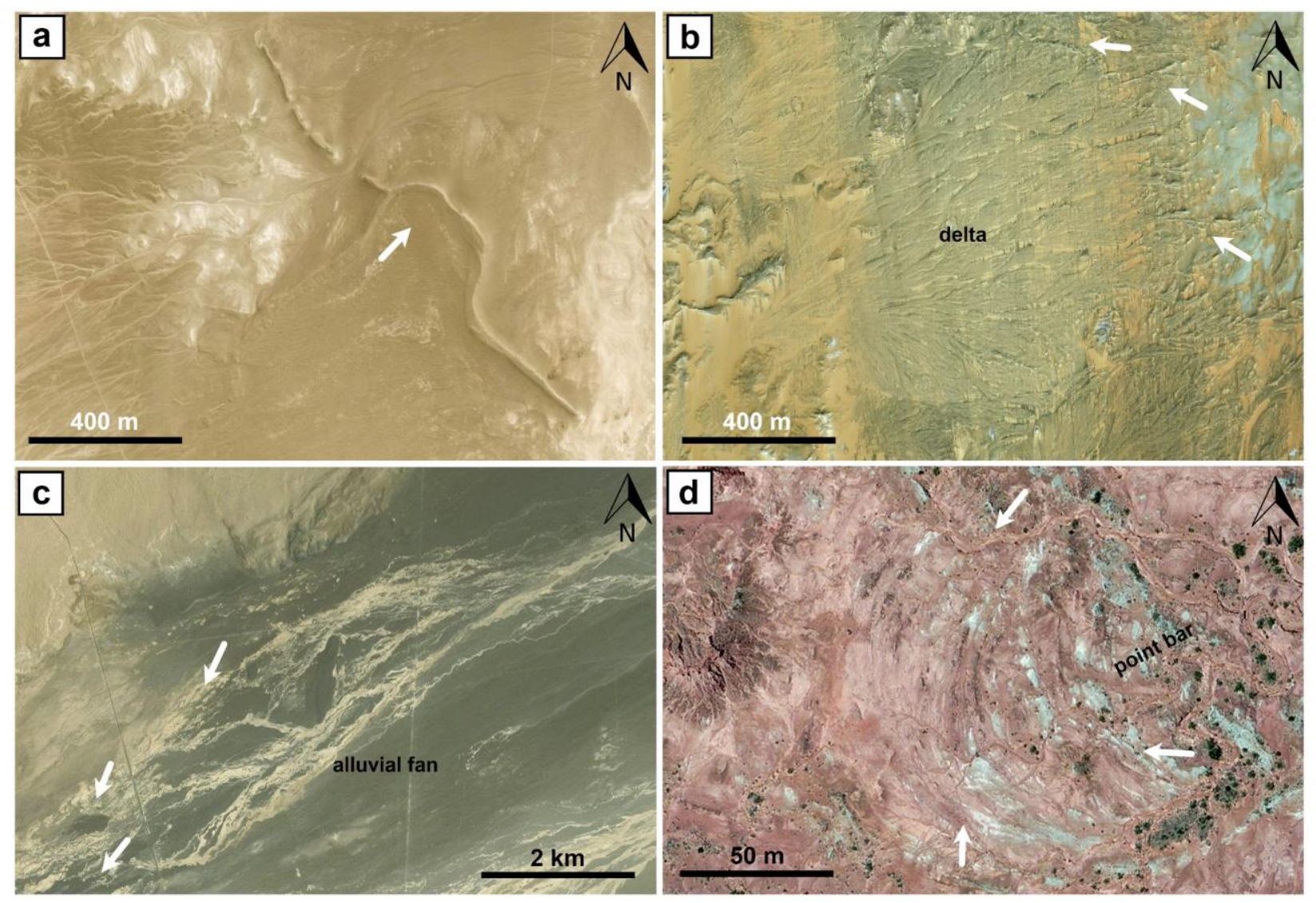

Fig. 20. ESRI world images showing: (a) Sinuous inverted channel in the Tablazo de Ica, Peru (14 $\left.29^{\prime} 07.87^{\prime \prime S}, 75^{\circ} 49^{\prime} 17.56 " \mathrm{~W}\right)$. (b) Inverted channels associated with deltaic deposits in Tushka paleolake, Egypt Egypt (22 $44^{\prime} 59.56 " \mathrm{~N}, 30^{\circ} 44$ '28.78"E). (c) Inverted channels in alluvial fan in the Chilean Atacama Desert Egypt (21 07' 10.83"S, $69^{\circ} 34$ '58.61"W). (d) Pointbars in relief inversion in North-Central Texas, USA (33 $\left.44^{\circ} 13.78^{\prime \prime} \mathrm{N}, 99^{\circ} 26^{\prime} 33.73 " \mathrm{~W}\right)$.

In a few cases, inverted stream channels occur on deltas and fans, such as the Columbus fan in New Mexico, USA (Fig. 13; Love and Seager, 1996), the inverted channels of the Fayum Depression, Egypt, and the newly-identified deltaic features at paleolake Tushka (Fig. 6; Zaki et al., 2018). Point bars have been identified in north-central Texas and in the Cañadón Asfalto Basin, Argentina (Edwards et al., 1983; Foix et al., 2012). Typical examples of exhumed meanders are 
found in the Dakhla Depression, Egypt (Brookes, 2003; Zaki et al., 2018), Cañadón Asfalto Basin, Argentina (Foix et al., 2012; Foix et al., 2018), and northern Niger (Smith et al., 2015).

In the Dakhla Depression, Egypt, and the Lop-Nor in China, exhumed meanders and channels are accompanied by yardangs (Fig. 21). Yardangs are erosional landforms that provide insights useful for reconstructing past and present wind regimes (e.g., McCauley et al., 1977; Goudie, 2007). In eastern Saudi Arabia, many hollows extending to tens of meters in diameter accompany inverted streams. These hollows indicate that a leaching process contributed to cementation (Miller, 1937). Some of the inverted-channel bodies were reworked to develop new drainage systems such as the Campaspe and Coliban Rivers in Victoria, Australia (Pain and Ollier, 1995), and the west of Esna city, Egypt (Zaki et al., 2018). Others developed twin, lateral streams; an example is the Bullengarook lava flow in Victoria, Australia, which is inverted, and flanked by two streams (Pain and Ollier, 1995).

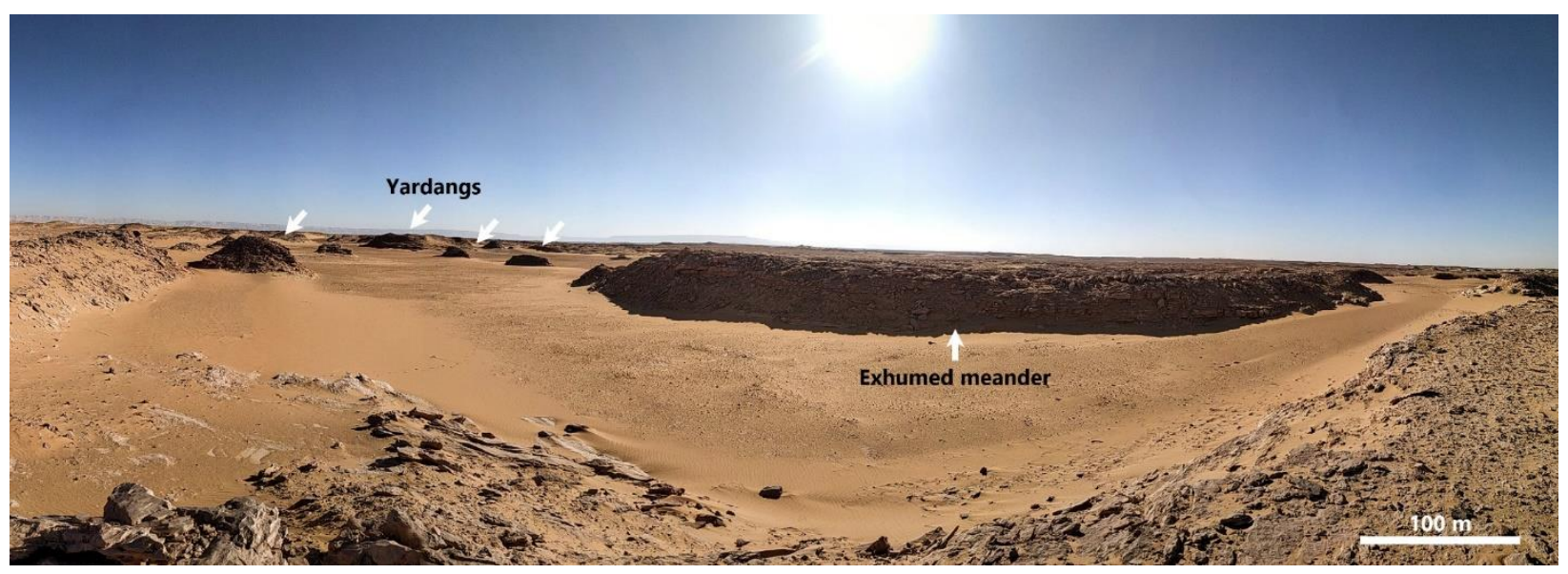

Fig. 21. Field photograph from the Dakhla Depression, Egypt, showing an exhumed, inverted stream meander and accompanying yardangs (25 $27^{\prime} 20.57^{\prime \prime N}, 29^{\circ} 12$ '58.82"E).

Circular features have been observed on the bodies of inverted channels in the Egyptian and Sudanese Sahara (Fig. 22). These circular features have diameters ranging from 2 to 5 meters. Crombie et al. (1997) interpreted these features in the Egyptian Sahara as spring mounds. In the Sudanese Sahara, there is no investigation on these features, but archeological studies in this area indicated to spring mounds in this area. These springs developed during late Quaternary time (Nicoll, 2004). 


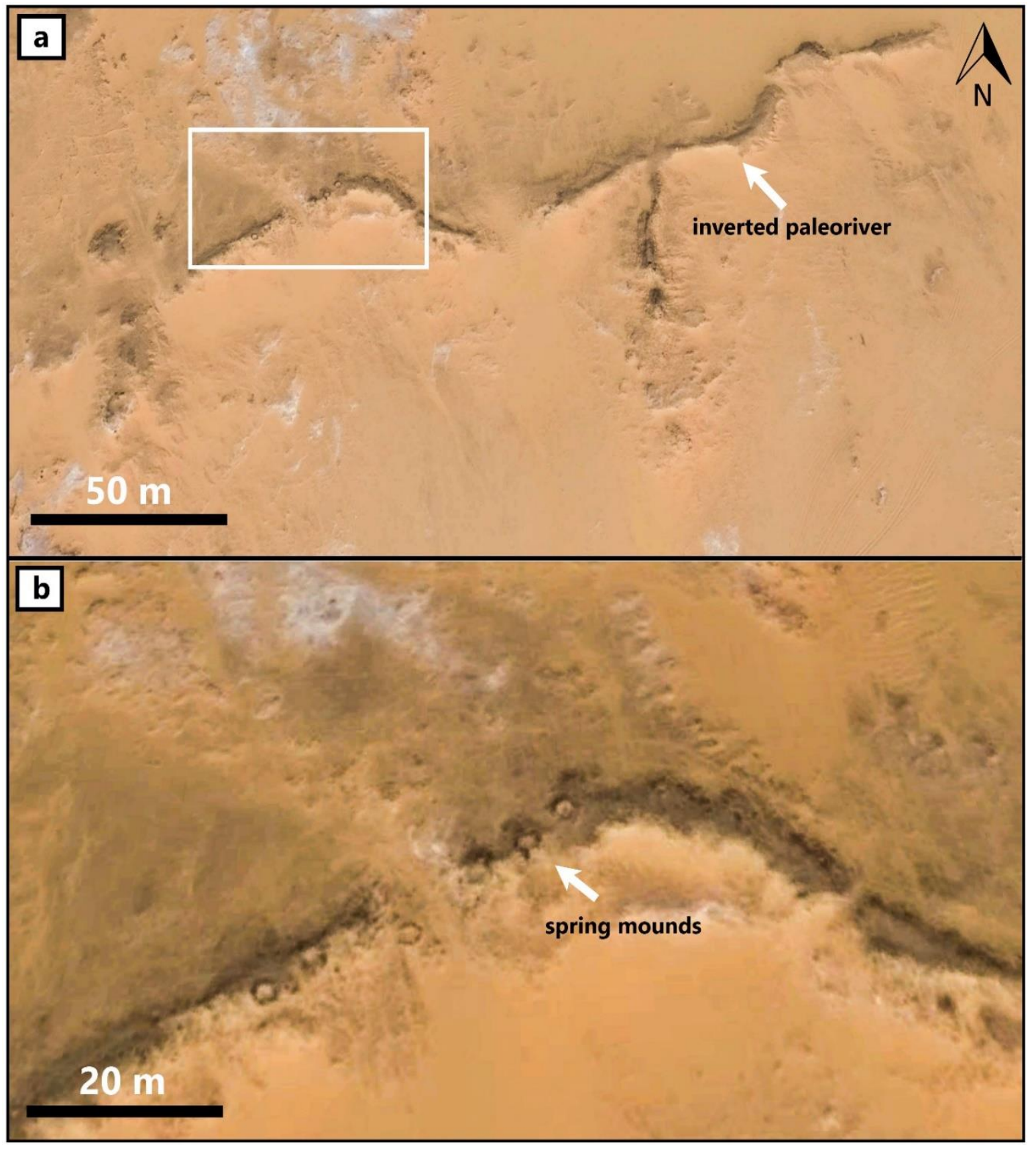

Fig. 22. Google Earth images showing $2-5 \mathrm{~m}$ circular features that are interpreted to be spring mounds superposed an inverted stream sediment in the northern part of Sudan $\left(21^{\circ} 56^{\prime} 19.08^{\prime \prime} \mathrm{N}\right.$, $\left.33^{\circ} 03^{\prime} 38.05^{\prime \prime} \mathrm{E}\right)$. 


\section{2. Sedimentology}

The sedimentary structures of inverted channel deposits on Earth are variable and depend on the local geologic and climatic conditions. In this section, we present a general overview of the documented sedimentary structures of inverted channels.

Some inverted channel bodies contain poorly to well sorted, clast-supported cobble gravels like those of the Mimbres drainage, New Mexico, USA (Love and Seager, 1996), southern part of the Egyptian Sahara (Zaki et al., 2018) (Fig. 23a, c, and d), Saudi Arabia (Matter et al., 2016). In this case, the ridge consists of one sedimentary unit (channel fill) overlying bedrock.

Cross-bedded structures with fine to coarse sand channel-belts have been reported from many examples, including Emery County, Utah (e.g., Williams et al., 2007; Williams et al., 2011), the Tassili N'Ajjer, Algeria and Libya (e.g., Girard et al., 2012), the Dakhla Depression, Egypt (Brookes, 2003; Zaki et al., 2018) (Fig. 23b, e, f, and g), and Ebro Basin, Spain (Cuevas Martínez et al., 2010).

The sedimentary structures can be also preserved beneath lavas in cases of relief inversion by volcanism. For example, McQueen et al. (2007) described $40 \mathrm{~m}$ of stratigraphy preserved as an inverted channel at El Capitan, New South Wales, Australia. The ridge consists of about $5 \mathrm{~m}$ of volcanic materials resting on about $1 \mathrm{~m}$ of river sediments that, in turn, rest on strongly weathered saprolite. In Victoria, Australia, a common feature is the development of silcrete between overlying basalt and underlying alluvium (Pain and Ollier, 1995). This silcrete may have developed by groundwater flow from adjacent slopes into the alluvium (Pain and Ollier, 1995). It is confined to the edges of the basalt flow, and its resistance to erosion is demonstrated by the fact that miners looking for gold in the alluvium would rather excavate through the basalt on top of the inverted channel rather than try to dig through the silcrete on the edge even though the latter would have meant a shorter route to non-cemented alluvium.

There is also very little stream sediment preserved in inverted channels developed by surface armouring. The channels beds are composed of large clasts that are not easily removed by either water or wind (Fig. 24; Giegengack, 1968). 


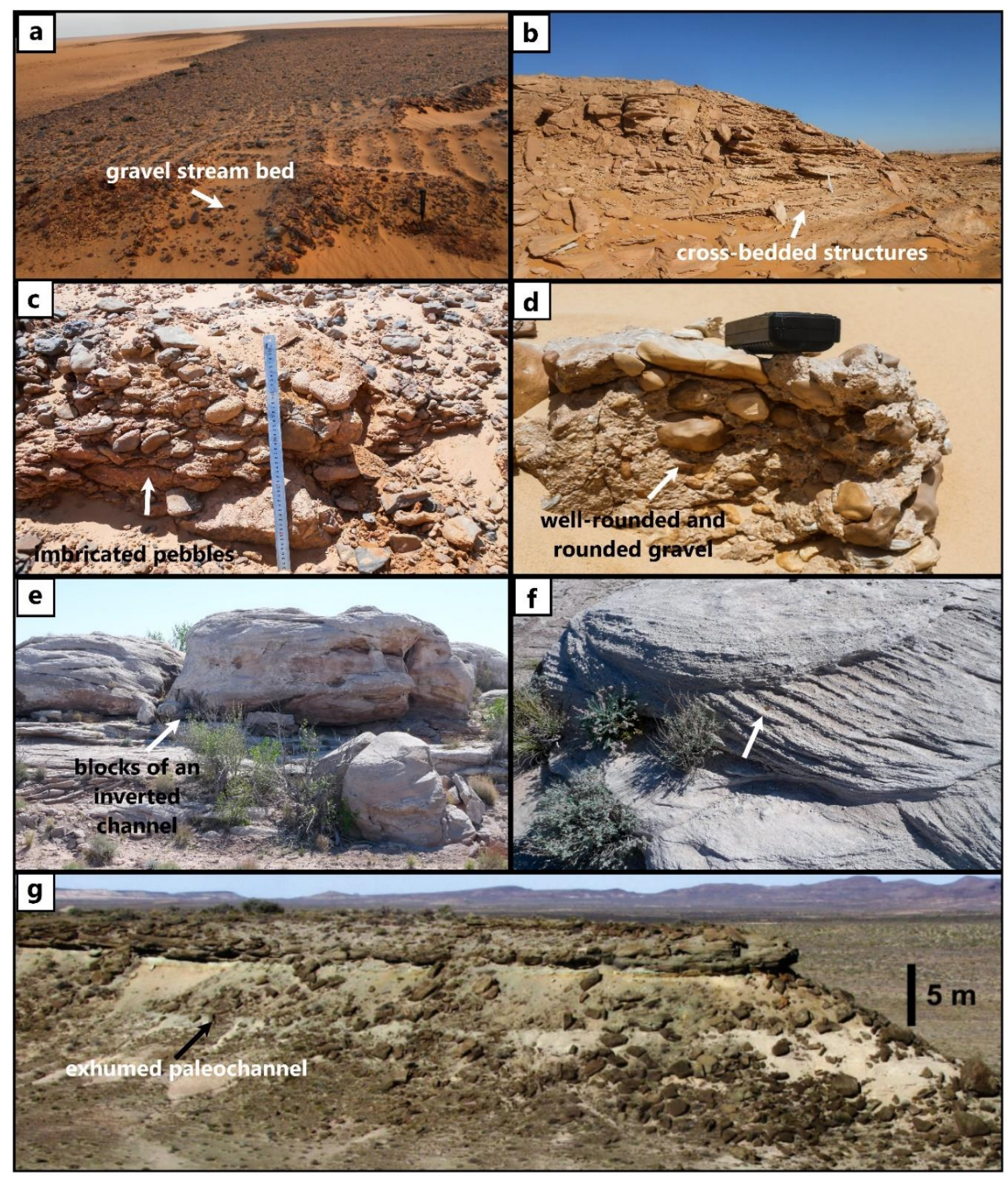

Fig. 23. Photographs showing the sedimentary structures in six inverted fluvial systems in the Egyptian Sahara, USA, and Argentina; (a) in the Arqin region (hammer for scale), (b) north of Gabal El-sadd (30 cm-ruler for scale), (c) Dakhla Depression, (d) west of Ghard Abu Muharik, (e), (f) near the Green River in Utah (19 mm-coin for scale in " $\mathrm{f}$ "), and (g) Cañadón Asfalto Basin, Argentina. The sedimentary structures in these systems record short and long-lived fluvial activity; in the Egyptian Sahara, the inverted gravel beds in the Arqin and Gabal El-Sadd regions document short fluvial events, but the inverted systems in the Dakhla Depression, west of Ghard Abu Muharik, Utah, and in the Cañadón Asfalto Basin record long-lived fluvial activity. Photograph (g) by Nicolás Foix. 


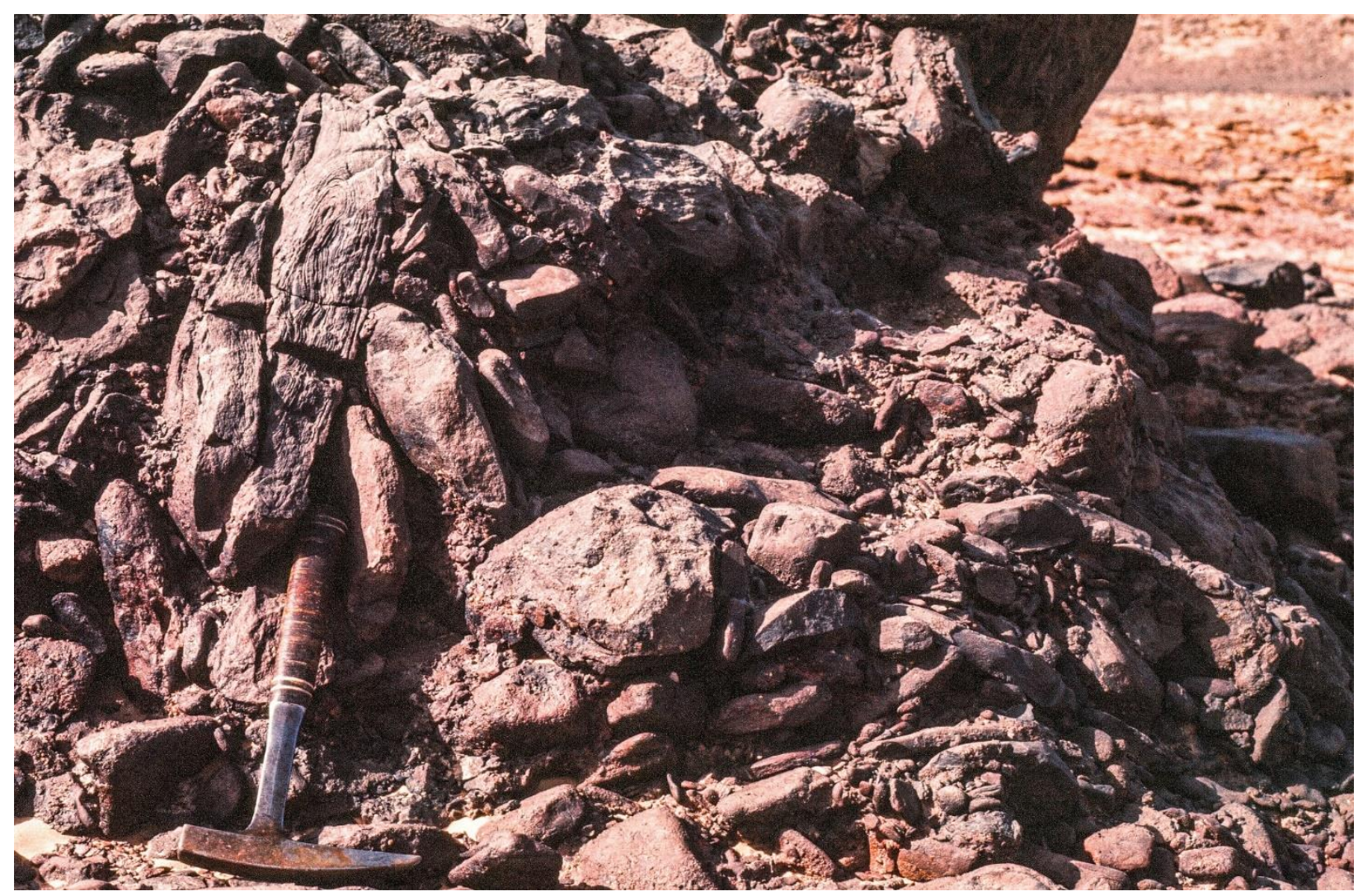

Fig. 24. Section from an inverted channel developed by surface armouring in southern Egypt. The large clasts cannot be removed by wind erosion. Photograph by Robert Giegengack from 1963.

\section{3. Geochronology}

There are at least three possibly overlapping stages in relief inversion for which it would be ideal to have a chronology:

1. The age and duration of formation of the original channels and their valleys.

2. The age and duration of processes (lava flows, cementing, lithification) that led to the erosional resistance of the channel sediment or valley fill.

3. The age and duration of the subsequent erosion that resulted in relief inversion. In the case of deep sediment lithification, relief inversion begins when the resistant material is reexposed at the surface; typically, this occurs some considerable time after deposition of the channel deposits.

Some of these are easier to ascertain than others, all extend over a period, and there may be some overlap. If we take the volcanism example of El Capitan, in New South Wales, Australia, we can note the following, based on ages from McQueen et al. (2007) and Cohen et al. (2007): (1) the 
leucitite flows that cover the alluvium and provide material resistant to erosion are about $17 \mathrm{Ma}$ K-Ar years old; (2) the valleys were cut into bedrock of Cambrian-Ordovician age, but exposure, weathering and valley development took place at some time in the late Mesozoic; (3) by the time the leucitite flows were emplaced, there was a weathering profile at least $10 \mathrm{~m}$ thick; and (4), since the deposition of the leucitite flows, the erosion rate has been $1-2 \mathrm{~m}$ per million years. Thus, stage 1 took place between the end of the Mesozoic and $17 \mathrm{Ma}$, a duration of at least $60 \mathrm{Ma}$. Stage 2 took place around $17 \mathrm{Ma}$, and stage 3 took place from $17 \mathrm{Ma}$, and still continues. If we combine stages 2 and 3 as representing the process of relief inversion, the "age" of the inverted relief is 17 Ma.

An example of inverted relief from deep sediment lithification is provided by Williams et al. (2007). In Utah, several units containing fluvial deposits were formed in the Late Jurassic and Early Cretaceous. They were then buried by more than a kilometer of Late Cretaceous sediments before being exhumed in the middle and late Cenozoic. Most of the development of inverted relief took place during the Neogene and Quaternary, so the age of the inverted relief is only 5-6 Ma.

We did not find sufficient information for the three overlapping stages (incision, sediment consolidation, then inversion) for all the examples. So we constrain the age of inverted channels on Earth for the incision stage based on absolute and relative ages provided in the literature. The age ranges from Upper Ordovician in the Tassili N'Ajjer in the border of Algeria and Libya (Girard et al., 2012) to late Holocene in the Bodélé Depression and Lower Ica Valley with an age 2.5 and 0.2 ka, respectively (Bristow et al., 2009; Beresford-Jones et al. 2009). Using carbon-14 dating, Busche (1988) determined the age of incising some inverted channels in the Kharga Depression at $225 \pm 40$ years.

In this study, we examined the relative and absolute ages of 74 sites representing the four mechanisms of inversion of relief (Fig. 25; Table 2). We found that inversion of relief by channel fill cementation could occur in as little as a few hundred years (Holocene)—such as the channels in Kharga Depression - to tens of million years (Paleocene, Eocene, and Oligocene time) as, for example, in sub-Saharan West Africa (Butt and Bristow, 2013), channels in the west of Ghrad Abu Muhraik in the Egyptian Sahara (Zaki et al., 2018), and Kalgoorlie region, Australia (Ollier et al., 1988). 
Broadly, we find that sediment lithification due to burial on Earth ranges in time from late Ordovician in Tassili N'Ajjer, Libya and Algeria to Late Miocene in in the offshore Cyprus, Syria, Lebanon and Israel ( 459 Ma to $\sim 6 \mathrm{Ma}$ ) (Girard et al., 2012; Madof et al., 2019). That the oldest examples are only Ordovician in age probably reflects not only the nature of rocks exposed at Earth's continental surfaces, but also the preservation of such clastic rocks as a function of Earth surface and crustal processes through time (e.g., Garrels and Mackenzie, 1969; Husson and Peters, 2018).

Volcanic inverted relief has a wide temporal range, extending from $17 \mathrm{Ma}$ at El Capitan, northeast of Cobar, New South Wales, Australia (McQueen et al. 2007; Cohen et al., 2007), to late Pleistocene at Mount Rainier, Washington, USA (Lescinsky and Sisson, 1998).

Channels inverted by surface armouring developed between $10 \mathrm{ka}$ in the Great Salt Lake Desert, USA (Oviatt et al., 2003) to $100 \mathrm{ka}$ in the Kumtagh Desert in China (Wang et al., 2015).

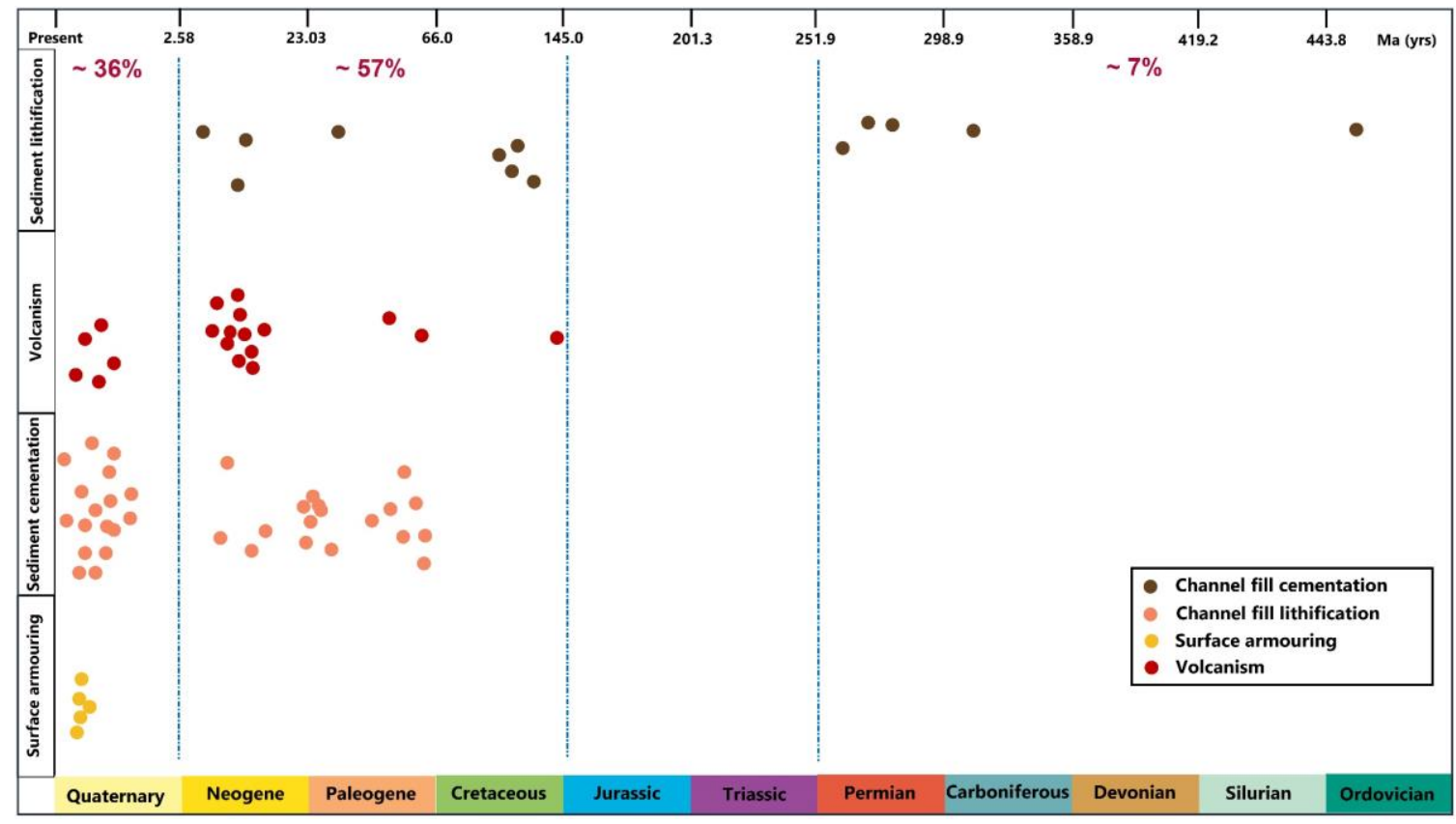

Fig. 25. Age of inverted-channel sediments on Earth for different mechanisms (surface and nearsubsurface cementation, lithification due to burial, volcanism, and surface armouring). Around of $36 \%$ of inverted fluvial channels developed by surface and near-subsurface cementation, volcanism, and surface armouring during Quaternary time (2.5 Ma). More than $57 \%$ of inverted fluvial channels formed by surficial cementation, sediment lithification due to deep burial, and volcanism developed since Cretaceous time to late Pliocene ( 145 Ma to $\sim 2.5 \mathrm{Ma})$. In the periods of Upper Ordovician to late Permian ( 252 Ma to $\sim 458 \mathrm{Ma}), \sim 7 \%$ of inverted fluvial channels were developed due to sediment lithification and volcanism. 


\section{IMPLICATIONS FOR MARTIAN SINUOUS RIDGES}

\section{1. Paleoclimate conditions associated with inverted channels}

The incision and inversion of stream channels on Earth are controlled by regional and global paleoclimatic events since the late Ordovician - early Silurian glacial period to the late Quaternary climate oscillation (Fig. 22; Girard et al., 2012; Giegengack, 1968; Zaki and Giegengack, 2016; Giegengack and Zaki, 2017). In the Tassili N'Ajjer, inverted sandstone bodies record highmagnitude flood events during the Late Ordovician (Girard et al., 2012). Then, a few examples of inverted channels from Argentina, southwest Australia, Morocco, Niger, Egypt, and Utah in USA developed during carboniferous, Permian, and Cretaceous periods and document huge amounts of information regarding the paleoenviromental conditions associated with these features in deep time (e.g., Fairbridge and Finkl, 1978; Williams et al, 2007; Brookes, 2003; Smith et al., 2015; Padgett and Ehrlich, 1976; Foix et al., 2012). Most inverted channels have formed during Paleogene, Neogene, and Quaternary periods over the globe. But during the late Quaternary, inverted channels document abrupt changes in the climate and the transition from wet to dry several times. The transition of the climate from wet to dry conditions have been identified in several sites, including examples from the southern part of Egypt (Giegengack, 1968; Giegengack and Zaki, 2017), Mimbres drainage, New Mexico, USA (Love and Seager, 1996), Bodélé Depression, Chad (Bristow et al., 2009), Kumtagh Desert (Wang et al., 2015), and Wadi Ad Dawsir and Wadi Sabha (Matter et al., 2016).

Formation of inverted channels passed through two climatic conditions: first, there was the climate in which the channels were formed and were conduits for clastic sediment transport (and deposition). Then, later, there were several episodes of dry/wet conditions or both, which affected the differential erosion of the materials exposed at Earth's land surface, to cause former channel or valley sediment or fill to become inverted.

Therefore, studying martian sinuous ridges that are interpreted to be remnants of fluvial activity at the global and regional scale could help us in constraining and identifying known and unknown paleoclimatic events of the early Mars. 


\section{2. Formation mechanisms of inverted channels}

Inversion of relief on Earth offers a wide range of morphological and sedimentological characteristics, where 107 inverted-channel sites were incised by precipitation-fed runoff and one site was incised by groundwater sapping at Lake Bogoria, Kenya (e.g., Miller, 1937; Giegengack, 1968; Williams et al., 2009; Girard et al., 2012; Renault et al., 2013).

Channel fill cementation in surface and near-subsurface environments for making the valley floor more resistant could be prevalent on Mars based on frequency of this process on Earth. Also, a few examples of inverted channels document volcanism pathway such as in the Mangala Valles (Tanaka and Chapman, 1990; Leverington, 2007) and northern Tharsis (Figure 1a of Zaki et al. 2018). Channel fill lithification due to deep burial could be rare like on Earth because of difficulties of returning lithified sediment to the surface, especially given the more benign tectonic situation. Perhaps the frequency of examples inverted by surface armouring could be greater on Mars because of its generally hyperarid climate over much of the last 2-3 billion years (e.g., Hurowitz et al., 2010; Zabrusky et al., 2012; Kite, 2019).

Ages of inverted stream channels on Earth provide some insights into at least the relative timescale of inversion of relief on Mars. Sediment lithification due to deep burial occurred over a wide range of time ( $459 \mathrm{Ma}$ to $\sim 6 \mathrm{Ma}$ ), surface and near-subsurface cementation occurred in a shorter range ( $66 \mathrm{Ma}$ to $0.2 \mathrm{ka}$ ), volcanism also has a wide timescale ( $145 \mathrm{Ma}$ to $\sim 87 \mathrm{ka})$, and surface armouring has a shorter timescale ( 100 ka to $\sim 10 \mathrm{ka}$ ) (e.g., Girard et al., 2012; Butt et al., 2013; Bristow et al., 2009; Wang et al., 2017). So, we find a relationship between the processes and timescale. Sediment lithification as a result of deep burial takes longer and there is thus preservation of older geologic and paleoclimatic records. Surface/near-subsurface cementation of channel sediment requires less time to develop, and surface armouring indicates an absence of burial and cementation processes with relatively large clasts and much less time. Volcanic eruptions can occur at any time. Although there is no evidence that volcanism has occurred in very recent times, including the era of spacecraft exploration (Christensen et al. 2005; Edgett et al, 2010), crater counting studies of volcanic surfaces shows that volcanism might have persisted throughout all of Mars history, with the youngest lavas being just 2.5-3 million years old (Vaucher et al., 2009; Halvey and Head, 2014). 


\subsection{Potential Earth analogues for the NASA Mars 2020 field site}

The Mars 2020 rover will land in western Jezero crater, where deltaic features with inverted channels are well-preserved (e.g., Fassett and Head, 2005; Schon et al., 2012; Goudge et al., 2018). Here, we note a unique site that hosted a paleolake during the mid-Pleistocene as an Earth analogue to Jezero crater. This site, paleolake Tushka, is in southern Egypt (Fig. 7). On the shoreline of the paleolake, there is a series of deltaic features with paleochannels in relief inversion. This site could be very useful in addressing the morphological and sedimentological issues of Jezero crater. The morphological and sedimentological issues could be relevant to the propagation fan-shaped deposits in a lake and dry land, then transition from wet to dry environments, then wind deflation that erode the fluvial landforms to provide sediment supply to form different forms sand dunes.

\section{CONCLUSIONS}

In this paper, we reviewed the distribution of sinuous ridges that are interpreted to be remnants of fluvial activity, terminology, the distribution and attributes of inverted stream channels on Earth at a global scale for the first time. General morphological, sedimentological, and geochronological aspects provide insights pertaining the paleoclimate and paleoenvronmental conditions on Earth.

We list 107 sites that offer 114 examples of inverted channels; 41 sites in Africa, 32 sites in North America, 13 sites in Asia, 11 sites in Australia, 7 sites in South America, 2 sites in Europe, and one site offshore from Cyprus, Syria, Lebanon and Israel. We find that early diagenetic (eogenesis) cementation is the main mechanism for making the channel-fill more consolidated on Earth with 67 examples $(\sim 59 \%)$. Thirteen examples $(\sim 11 \%)$ developed by channel sediment lithification due to deep burial (mesogenesis), 26 examples ( 23\%) formed by volcanism, 7 examples ( 6\%) due to surface armouring, and one site $(\sim 1 \%)$ due to decreased volume of bank-forming peat in the Okavango Delta in Botswana. Then, water erosion, exhumation by tectonic events, and wind deflation are the main causes of eroding fluvial channels to be topographically inverted. The estimated wind deflation rates that were involved in eroding the inverted channels range from 10 $\mathrm{mm} /$ year on the dustiest place on earth in the Bodélé Depression, Chad to $0.21 \mathrm{~mm} / \mathrm{year}$ in Kumtagh Desert, China.

Inverted stream channels on Earth exhibit different forms, including flat-topped linear sinuous channels, deltas, fluvial fans, meanders, and point bars. Some landforms are associated with the 
development of inverted stream channels, including yardangs, hollows, spring mounds, and small alcoves. We find that the sedimentary structure of these features varies from bodies containing poorly to well sorted, clast-supported cobble gravels to cross-bedded structure with fine to coarse sand grains. In the case of volcanism, the sedimentary structure consists of two or more stratigraphic units. Surface armouring leaves behind large clasts but preserves little or no sedimentary structure. The age of inverted stream channels on Earth ranges from the Upper Ordovician (458.4 $\pm 0.9 \mathrm{Ma})$ to Holocene $(225 \pm 40$ years) recording several climatic events from the upper Ordovician glaciation to late Quaternary climate oscillation.

Our global synthesis of inverted channels on Earth has implications pertaining to formational conditions of martian sinuous ridges; based on the occurrence of channel fill cementation that occurs on the surface and near-subsurface settings on Earth for consolidation of paleochannels sediment ( $59 \%)$, shallow, near-subsurface cementation of channel sediment could be prevalent on Mars. This suggestion is consistent with the lack of documenting inverted channels by volcanism on Mars and difficulties of returning materials to the Martian surface due to the tectonic setting. Channel surface armouring frequency could be more common on Mars, particularly because Mars has been hyperarid for long time and wind erosion has played an important role. Therefore, detailed studies on inverted channels at the global scale on Mars will provide new information about the early climate of Mars, particularly transition from wet to dry conditions.

Finally, through a survey of inverted channel sites on Earth that mentioned in the literature and what we observed from remotely-sensed data, we found a new site that might be helpful as a terrestrial analogue for Mars 2020 landing site. This site is in the southern part of Egypt, is a typical place on Earth simulating the conditions of Jezero delta, where paleochannels are associated with deltas in relief inversion hosted by a paleolake. Further studies in this site could help in addressing geomorphological and sedimentological issues pertaining to propagation of fan-shaped deposited in a lake and dry setting, transition from wet to dry conditions, and wind erosion processes that provide sediment supply to develop different patterns of sand dunes. 


\section{Acknowledgements}

Abdallah Zaki gratefully acknowledges the support of the Swiss Confederation excellence fellowships program (fellowship No: 2017.1006). The authors are grateful to Robert Giegengack who gave us a permission to use one of his field photographs (Fig. 24), Andrew Madof for providing material for Fig. 15, Nicolás Foix for Fig. 23g, and Seán Doran for Fig 3d. The authors thank Sanjeev Gupta of Imperial College, London, discussions that contributed to this manuscript. K. Edgett acknowledges partial funding support through the NASA Mars Reconnaissance Orbiter Context Camera investigation. 


\section{References}

Adler, J.B., Bell, J.F., Fawdon, P., Davis, J., Warner, N.H., Sefton-Nash, E., Harrison, T.N., 2018. Hypotheses for the origin of the Hypanis fan-shaped deposit at the edge of the Chryse escarpment, Mars: is it a delta? Icarus 319, 885-908. https://doi.org/10.1016/j.icarus.2018.05.021

Anand, R.R., Paine, M. 2002. Regolith geology of the Yilgarn Craton, Western Australia: implications for exploration. Australian Journal of Earth Sciences 49, 3-162. https://doi.org/10.1046/j.1440-0952.2002.00912.x

Anand, R.R., Smith, R.E., 1993. Regolith distribution, stratigraphy and evolution in the Yilgarn Craton - implications for exploration. In: P.R. Williams and J.A. Haldane (Editors), Kalgoolie 93, An International Conference on Crustal Evolution, Metallogeny and Exploration of the Eastern Goldfields. Extended Abstracts. AGSO Record, 1993/54, pp. 187193.

Anderson, R.B., Bell, J.F. III, 2010. Geologic mapping and characterization of Gale crater and implications for its potential as a Mars Science Laboratory landing site. Mars 5, 76-128. https://doi.org/10.1555/mars.2010.0004

Ansan, V., Loizeau, D., Mangold, N., Mouelic, S.L., Carter, J., Poulet, F., Dromart, G., Lucas, A., Bibring, J.O., Gendrin, A., Gondet, B., Langevin, Y., Masson, Ph., Murchie, S., Mustard, J.F., Neukum, G., 2011. Stratigraphy, mineralogy, and origin of layered deposits inside Terby crater, Mars. Icarus 211, 273-304. https://doi.org/10.1016/j.icarus.2010.09.011

Baker, V., Hamilton, C.W., Burr, V., Gulick, V., Komatsu, G., Luo, W., Rice Jr., J.W., Rodriguez, J.A.P., 2015. Fluvial geomorphology on Earth-like planetary surfaces: A review. Geomorphology 245, 149-182. https://doi.org/10.1016/j.geomorph.2015.05.002

Balme, M., P. Grindrod, E. Sefton-Nash, J. Davis, S. Gupta, P. Fawdon, P. Sidiropoulos, V. Yershov, Muller, J-P., 2015. Aram Dorsum: A Noachian inverted fluvial channel system and candidate ExoMars 2018 rover landing site. Lunar and Planetary Science Conference 46, 1321, Lunar and Planetary Institute Contribution 1832, Houston, Texas. 
Banerjee, I., McDonald, B.C., 1975. Nature of esker sedimentation. In: Jopling, A.V., McDonald, B.C. (Eds.), Glaciofluvial and Glaciolacustrine Sedimentation. SEPM Special Publ. 23, 132154. https://doi.org/10.2110/pec.75.23.0132

Barnes, L.C. and Pitt, G.M. 1976. The Tallaringa palaeodrainage system. Quarterly Geological Notes, Geological Survey of South Australia 59, 7-10.

Barnes, L.C., Pitt, G.M., 1976. The Mirackina Conglomerate. Quarterly Geological Notes, Geological Survey of South Australia 59, 2-6.

Bell, R.B., Williamson, I.T., 2013. A Palaeocene intracanyon-style lava emplaced during the early shield-building stage of the Cuillin Volcano, Isle of Skye, NW Scotland. Earth and Environmental Science Transactions of the Royal Society of Edinburgh 104(2), 205-230. https://doi.org/10.1017/S1755691013000509

Beresford-Jones, D.G., Susana, A.T., Whaley, O.Q, Chepstow-Lusty, A.J., 2009. The role of Prosopis in ecological and landscape change in the Samaca Basin, Lower Ica Valley, South Coast Peru from the Early Horizon to the Late Intermediate Period. Latin American Antiquity 20, 303-332. https://doi.org/10.1017/S1045663500002650

Bernhardt, H., H. Hiesinger, M. A. Ivanov, O. Ruesch, G. Erkeling, D. Reiss, 2016. Photogeologic mapping and the geologic history of the Hellas basin floor, Mars. Icarus 264, 407-442. https://doi.org/10.1016/j.icarus.2015.09.031

Bhattacharya, J. P., T. H. D. Payenberg, S. C. Lang, M. Bourke, 2005. Dynamic river channels suggest a long-lived Noachian crater lake on Mars. Geophysical Research Letters 32, L10201. https://doi.org/10.1029/2005GL022747

Billingsley, G.H., Priest, S.S., Felger, T.J., 2007. Geologic map of Wupatki National Mounment and Vincinity, Coconino, Northern Arizona. USGS Scientific Investigation Map 2958. https://doi.org/10.3133/sim2958

Blumenschine, R.J., Stanistreet, I.G., Njau, J.K., Bamford, M.K., Masao, F.T., Albert, R.M.,Fernández-Jalvo, Y., 2012. Environments and hominin activities across the FLKPeninsula during Zinjanthropus times (1.84 Ma), Olduvai Gorge, Tanzania. J. Hum. Evol. 63 (2), 364-383. https://doi.org/10.1016/j.jhevol.2011.10.001. 
Bristow, C.S., Drake, N., Armitage, S., 2009. Deflation in the dustiest place on Earth: The Bodélé Depression, $\quad$ Chad. $\quad$ Geomorphology $\quad$ 50-58. https://doi.org/10.1016/j.geomorph.2007.12.014

Brookes, I.A., 2003. Palaeofluvial estimates from exhumed meander scrolls, Taref Formation (Turonian), Dakhla Region, Western Desert, Egypt. Cretaceous Research 24, 97-104. https://doi.org/10.1016/S0195-6671(03)00033-8

Bryan, K., 1940. Gully gravure - a method of slope retreat. Journal of Geomorphology 3, 89-107.

Bryan, R., 2003. Erodibility. In Goudie, Encyclopedia of Geomorphology, Routledge, p. 360.

Burr, D. M., M-T. Enga, R. M. E. Williams, J. R. Zimbelman, A. D. Howard, T. A. Brennand, 2009. Pervasive aqueous paleoflow features in the Aeolis/Zephyria Plana region, Mars. Icarus 200, 52-76. https://doi.org/10.1016/j.icarus.2008.10.014

Burr, D. M., R. M. E. Williams, K. D. Wendell, M. Chojnacki, Emery, J. P., 2010. Inverted fluvial features in the Aeolis/Zephyria Plana region, Mars: Formation mechanism and initial paleodischarge estimates. Journal of Geophysical Research 115, E07011. https://doi.org/10.1029/2009JE003496

Burr, D.M., Williams, R.M.E., 2009. The Stanislaus Table Mountain: Observations of A lavacapped inverted paleochannel for interpretation of inverted paleochannels on Mars. $40^{\text {th }}$ Lunar and Planetary Science Conference, \#1633.

Burr, D.M., Williams, R.M.E., Nussbaumer, J., Zimbelman, J.R., 2006. Multiple, distinct, (glacio?) fluvial paleochannels throughout the western Medusae Fossae Formation, Mars. Lunar Planet. Sci. 37. Abstract 1367.

Busche, D., 1988. Post-Neolithic changes of aeolian morphodynamics in the Kharga and Toshka depressions, southern Egypt. Bulletin de la Société Géologique de France IV (6): 1053-1061. https://doi.org/10.2113/gssgfbull.IV.6.1053

Bussert, R., Eisawi, A.A.M., Hamed, B., Babikir, A.A., 2018. Neogene palaeochannel deposits in Sudan - Remnants of a trans-Saharan river system?. Journal of African Earth Sciences 141, 9-21. https://doi.org/10.1016/j.jafrearsci.2017.11.040 
Butt, C.R.M., Bristow, A.P.J., 2013. Relief inversion in the geomorphological evolution of subSaharan West Africa. Geomorphology, 165, 26. https://doi.org/10.1016/j.geomorph.2012.11.024

Butzer, K.W., 1980. The Holocene Lake Plain of North Rudolph, East Africa. Physical Geography 1, 42-58. https://doi.org/10.1080/02723646.1980.10642188

Butzer, K.W., Hansen, C.L., 1968. Desert and river in Nubia. Madison, University of Wisconsin Press, 497 p.

Caballero, J.H., Rendón, A., Gallego, J.J., Uasapud, N.V., 2016. Inter-Andean Cauca River Canyon. In Hermelin, M: Landscapes and landforms of Colombia. Springer, 155-166. https://doi.org/10.1007/978-3-319-11800-0_13

Cas, R. A. F. et al.,2011. The flow dynamics of an extremely large volume pyroclastic flow, the 2.08-Ma Cerro Galan Ignimbrite, NW Argentina, and comparison with other flow types. Bull. Volcanol. 73, 1583-1609. https://doi.org/10.1007/s00445-011-0564-y

Channer, M.A., Ricketts, J.W., Zimmerer, M., Heizler, M., Karlstrom, K.E., 2015. Surface uplift above the Jemez mantle anomaly in the past $4 \mathrm{Ma}$ based on ${ }^{40} \mathrm{Ar} /{ }^{39} \mathrm{Ar}$ dated paleoprofiles of the Rio San Jose, New Mexico, USA. Geosphere 11 (5): 1384-1400. doi: https://doi.org/10.1130/GES01145.1

Chapman, M. G., Tanaka, K. L., 1993. Geologic map of the MTM -05152 and -10152 quadrangles, Mangala Valles region of Mars, scale 1:500,000, U. S. Geological Survey Miscellaneous Investigation Map I-2294. https://doi.org/10.3133/i2294

Chapman, M., 2007. The geology of Mars: Evidence from Earth-based analogs, Cambridge Planetary Science, $\quad$ Cambridge University $\quad$ Press, $484 \quad$ p. https://doi.org/10.1017/CBO9780511536014

Christensen PR, Gorelick N, Fergason R, 2005. Searching for change in the martian night: investigating nighttime temperature anomalies using THEMIS. Eos, Trans Am Geophys Union Fall Suppl 86(52):P24A-01. 
Church, S.E., Swanson, D.A., Williams, D.L., Clayton, G.A., Close, T.J, Peters, T.J., 1983. Mineral resource potential map of the Goat Rocks Wilderness and adjacent roadless areas, Lewis and Yakima counties, Washington. Miscellaneous Field Studies Map 1653-A. https://doi.org/10.3133/mf1653A

Clarke, J.D.A., Stoker, C.R., 2011. Concretions in exhumed and inverted channels near Hanksville Utah: Implications for Mars. International Journal of Astrobiology 10(3), 161-175. https://doi.org/10.1017/S1473550411000048

Colton, H.S., 1937. The Basaltic cinder cones and lava flows of the San Francisco Mountain volcanic field. Museum of Northern Arizona Bulletin 10, 58p.

Cowart, J.C., Rogers, A.D., Edwards, C.S., 2019. Mapping and characterization of Martian intercrater bedrock plains: Insights into resurfacing processes in the Martian cratered highlands, J. Geophys. Res. Planets. https://doi.org/10.1029/2019JE006062

Craddock, R. A., Maxwell, T.A., 1990. Resurfacing of the martian highlands in the Amenthes and Tyrrhena region. Journal of Geophysical Research 95(B9), 14,265-14,278. https://doi.org/10.1029/JB095iB09p14265

Crombie, M.K., Arvidson, R.E., Sturchio, N.C., El Alfy, Z., Zeid, K.A., 1997. Age and isotopic constraints on Pleistocene pluvial episodes in the Western Desert, Egypt. Palaeogeogr. Palaeoclimatol. Palaeoecol., 130, 337-355. https://doi.org/10.1016/S0031-0182(96)00134-4

Cuevas Martínez , J.L.C., Cabera, J.L., Marcuello, L., Cazo, A., Mazro, P., Bellmunt, M., 2010. Exhumed channel sandstone networks within fluvial fan deposits from the Oligo-Miocene Caspe Formation, south-east Ebro Basin (north-east Spain). Sedimentology, 57, 162-189. https://doi.org/10.1111/j.1365-3091.2009.01096.x

Cundari, A. and Oilier, C.D., 1970. Australian landform example no. 17; Inverted relief due to lava flows along valleys. Australian Geographer 11(3), 291-293. https://doi.org/10.1080/00049187008702563

Davis, J. M., M. Balme, P. M. Grindrod, R. M. E. Williams, Gupta, S., 2016. Extensive Noachian fluvial systems in Arabia Terra: Implications for early Martian climate, Geology. https://doi.org/10.1130/G38247.1 
Davis, J.M., Gupta, S., Balme, M., Grindrod, P.M., Fawdon, P., Dickeson, Z.I., Williams, R.M.E., 2019. A diverse array of fluvial depositional systems in Arabia Terra: Evidence for midNoachian to early Hesperian rivers on Mars. J. Geophys Res. Planets 124, 1913-1934. https://doi.org/10.1029/2019JE005976

Day, M., Edgett, K.S., Stumbaugh, D., 2019. Ancient Stratigraphy Preserving a Wet- to- Dry, Fluvio- Lacustrine to Aeolian Transition Near Barth Crater, Arabia Terra, Mars. JGR Planets, https://doi.org/10.1029/2019JE006226

de Wit M.C., 2016. Dwyka Eskers Along the Northern Margin of the Main Karoo Basin. In: Linol B., de Wit M. (eds) Origin and Evolution of the Cape Mountains and Karoo Basin. Regional Geology Reviews. Springer, Cham https://doi.org/10.1007/978-3-319-40859-0_9

Denbow, J., Smith, J., Ndobochani, N.M., et al., 2008. Archaeological excavations at Bosutswe, Botswana: cultural chronology, paleo-ecology and economy. J. Archaeol. Sci. 35, 459-480. https://doi.org/10.1016/j.jas.2007.04.011

Derr, M.E., 1974, Sedimentary structure and depositional environmentof paleochannels in the Jurassic Morrison Formation near Green River, Utah: Brigham Young, University Geology Studies, 21, 3-39.

Di Pietro, I., Ori, G., Pondrelli, M., Salese, F., 2018. Geology of Aeolis Dorsa alluvial sedimentary basin, Mars. Journal of Maps 14 (2), https://doi.org/10.1080/17445647.2018.1454350

DiBiase, R. A., A. B. Limaye, J. S. Scheingross, W. W. Fischer, M. P. Lamb (2013). Deltaic deposits at Aeolis Dorsa: Sedimentary evidence for a standing body of water on the northern plains of Mars. Journal of Geophysical Research Planets 118, 1284-1302. https://doi.org/10.1002/jgre.20100

Dickson, J.L., Lamb, M.P., Williams, R.M.E., Hayden, A.T., 2019. New global map of fluvial sinuous ridges on Mars: Evidence for large, globally-distributed Noachian/Hesperian depositional rivers. $9^{\text {th }}$ International Conference on Mars, \#2089.

Diffendal, R.F., 1994. Geomorphic and structural features of the Alliance 1" X 2" Quadrangle, western Nebraska, discernible from synthetic-aperture radar imagery and digital shadedrelief maps. Contributions to Geology, University of Wyoming 30, 137-147. 
Doctor, D.H., Orndorff, W., Maynard, J., Heller, M.J., Casile, G.C., 2014. Karst geomorphology and hydrology of the Shenandoah Valley near Harrisonburg, Virginia. In: Bailey CM, Coiner LV (Eds.) Elevating geoscience in the Southeastern United States: NEW ideas about old terranes - field guides for the GSA southeastern section meeting. Blacksburg, Virginia, 2014, Geol Soc Am Field Guide 35:161-213. https://doi.org/10.1130/2014.0035(06)

Edgett, K. S., 2005. The sedimentary rocks of Sinus Meridiani: Five key observations from data acquired by the Mars Global Surveyor and Mars Odyssey orbiters. Mars 1, 5-58. https://doi.org/10.1555/mars.2005.0002

Edgett, K. S., B. A. Cantor, T. N. Harrison, M. R. Kennedy, L. J. Lipkaman, M. C. Malin, L. V. Posiolova, D. E. Shean, 2010. Active and recent volcanism and hydrogeothermal activity on Mars, Abstract 34.06, Bulletin of the American Astronomical Society 42(4), 1016. (42nd American Astronomical Society Division for Planetary Sciences Annual Meeting; 3-8 October 2010, Pasadena, California, USA).

Edgett, K. S., L. Saper, 2013. Candidate Mars 2020 landing site: Water-lain sedimentary rock in contact with a lava flow of regional extent at Vistula Valles and Chryse Planitia, Response to 2013 NASA/JPL-Caltech Call for Imaging of Candidate Landing Sites for the 2020 Mars Rover Mission, 3 p. https://doi.org/10.13140/RG.2.1.1984.1446

Edgett, K. S., M. C. Malin, MRO MARCI-CTX Science and Operations Teams, 2008. MRO Context Camera (CTX) investigation Primary Mission results, Abstract P31D-04. Eos, Transactions of the American Geophysical Union 89(52), Fall Meeting Supplement.

Edgett, K. S., R. M. E. Williams, 2004. Valleys and channels in the Martian rock record, Workshop on Mars Valley Networks (Kohala Coast, Hawaii, USA), Smithsonian Institution, Washington, DC, USA.

Edwards, M.B., Eriksson, K.A. and Kier, R.S., 1983. Paleochannel geometry and flow patterns determined from exhumed Permian point bars in north-central Texas. Journal of Sedimentary Petrology 53, 1261-1270. https://doi.org/10.1306/212F835A-2B24-11D7$\underline{8648000102 \mathrm{C} 1865 \mathrm{D}}$ 
Eggleton, R.A. (Ed.), 2001. The Regolith Glossary: Surficial Geology, Soils and Landscapes. Cooperative Research Centre for Landscape Evolution and Mineral Exploration, Australian National University, Canberra, 144p. Retrieved 26 November 2019 from http://crcleme.org.au/Educ/rgg/docs/RegolithGlossary.pdf

Ellery, W.N., Ellery, K., McCarthy, T.S., Cairncross, B., Oelofse, R., 1989. A peat fire in the Okavango Delta, Botswana, and its importance as an ecosystem process. Afr. J. Ecol. 27, 7 21. https://doi.org/10.1111/j.1365-2028.1989.tb00924.x

Embabi, N., 2018. Landscapes and landforms of Egypt: Landforms and evolution. Springer, Cham, 336 p. https://doi.org/10.1007/978-3-319-65661-8

Embabi, N.S., 2004. The geomorphology of Egypt. Landforms and evolution: Vol 1. The Nile Valley and the Western Desert. Cairo, Egyptian Geographical Society, Special Publication, $447 \mathrm{p}$.

Fairbridge, R.W., Finkl, C.W., 1978. Geomorphic analysis of the rifted cratonic margins of Western Australia. Z. Geomorphol., 22( 4), 369-389.

Fassett, C. I., J. W. Head III., 2007. Layered mantling deposits in northeast Arabia Terra, Mars: Noachian-Hesperian sedimentation, erosion, and terrain inversion. Journal of Geophysical Research 112, E08002. https://doi.org/10.1029/2006JE002875

Fassett, C.I., Head III, J.W., 2005. Fluvial sedimentary deposits on Mars: Ancient deltas in a crater lake in the Nili Fossae region. Geophysical Research Letters, https://doi.org/10.1029/2005GL023456

Fassett, C.I., Head, J.W., 2005. Fluvial sedimentary deposits on Mars: Ancient deltas in a crater lake in the Nili Fossae region, Geophysical Research Letters, https://doi.org/10.1029/2005GL023456

Fawdon, P., Gupta, S., Davis, J. M., Warner, N. H., Adler, J. B., Balme, M. R., et al., 2018. Hypanis Valles Delta: The last high stand of an ocean on early Mars? Earth and Planetary Science Letters, 500, 225-241. https://doi.org/10.1016/j.eps1.2018.07.040

Finkl, C.W., Fairbridge, R.W., 1979. Paleogeographic evolution of a rifted cratonic margin: S.W. Australia. Palaeogeogr. Palaeocl., 26, 221-252. https://doi.org/10.1016/0031$\underline{0182(79) 90150-0}$ 
Foix, N., Allard, J.O., Paredes, J.M., Giacosa, R.E., 2012. Fluvial styles, palaeohydrology and modern analogues of an exhumed, Cretaceous fluvial system: Cerro Barcino Formation, Cañadón Asfalto Basin, Argentina. Cretaceous Research, 34, 298-307. https://doi.org/10.1016/j.cretres.2011.11.010

Foix, N., Allard, J.O., Ocampo, S.M., Paredes, J.M. 2018. Afloramientos tridimensionales de paleocanales exhumados (Grupo Chubut, Cuenca de Cañadón Asfalto) como análogos de reservorios. 10th Congreso de Exploración y Desarrollo de Hidrocarburos, Sesiones Generales: Energía y Sociedad, aliados inseparables, Instituto Argentino del Petróleo y el Gas, 877-890.

Fortezzo, C. M., 2013. Geology and geochronology of Hadriacus Palus, Mars. Geological Society of America Abstracts with Programs 45(7), 404, abstract \#163-7.

Friend, P.F., Marzo, M. Nijimsn, W., Puigdefabregas, C., 1981. Fluvial sedimentology in the Tertiary South Pyrenean and Ebro basins, Spain. In: Elliott, T. (Editor), Field guides to modern and ancient fluvial systems in Britain and Spain: International Fluvial Conference, University of Keele, p. 4.1-4.50

Gardner, T.W., 1983. Paleohydrology and paleomorphology of a Carboniferous meandering fluvial sandstone. Journal of Sedimentary Research 53, 991-1005. https://doi.org/10.1306/212F8300-2B24-11D7-8648000102C1865D

Garrels, R.M., Mackenzie, F.T., 1969. Sedimentary rock types: Relative proportions as a function of geological time. Science 163, 570-571. https://doi.org/10.1126/science.163.3867.570

Giegengack, R.F., 1968. Late Pleistocene History of the Nile Valley in Egyptian Nubia. Unpublished Ph.D. Thesis, Yale University.

Giegengack, R.F., Zaki, A.S., 2017. Inverted topographic features, now submerged beneath the water of Lake Nasser, document a morphostratigraphic sequence of high-amplitude latePleistocene climate oscillation in Egyptian Nubia. Journal of African Earth Sciences. https://doi.org/10.1016/j.jafrearsci.2017.06.027

Gillies, J.A., Nickling, W.G., Tilson, M., 2009. Ventifacts and wind-abraded rock features in the Taylor Valley, Antarctica. Geomorphology, 107, 149-160. https://doi.org/10.1016/j.geomorph.2008.12.007 
Girard, F., Ghienne, J.F., Rubino, J.L., 2012. Channelized sandstone bodies ('cordons') in the Tassili N'Ajjer (Algeria \& Libya): snapshots of a Late Ordovician proglacial outwash plain. Geological Society, London, Special Publications, 368, 355-379. https://doi.org/10.1144/SP368.3

Goudge, T.A., Mohrig, D., Cardenas, B.T., Hughes, C.M., Fasset, C.I., 2018. Stratigraphy and paleohydrology of delta channel deposits, Jezero crater, Mars. Icarus 301, 58-75. https://doi.org/10.1016/j.icarus.2017.09.034

Goudge, T.A., Mohrig, D., Cardenas, B.T., Hughes, C.M., Fassett, C.I., 2018. Stratigraphy and paleohydrology of delta channel deposits, Jezero crater, Mars. Icarus 301, 58-75. https://doi.org/10.1016/j.icarus.2017.09.034

Goudie, A., 2007. Mega-yardangs: A global analysis. Geography Compass, 1, 65-81. https://doi.org/10.1111/j.1749-8198.2006.00003.x

Grant, J. A., Schultz, P. H., 1990. Gradational epochs on Mars: Evidence from west-northwest of Isidis basi and Electris. Icarus 84, 166-195. https://doi.org/10.1016/0019-1035(90)90164-5

Grant, J. A., Wilson, A.S., 2012. A possible synoptic source of water for alluvial fan formation in southern Margaritifer Terra, Mars. Planetary and Space Science 72, 44-52. https://doi.org/10.1016/j.pss.2012.05.02

Guilbaud, M.N., Siebe, C., Layer, P., Salinas, S., Castro-Govea, R., Garduño-Monroy, V.H., Le Corvec, N., 2011. Geology, geochronology, and tectonic setting of the Jorullo Volcano region, Michoacán, México. J. Volcanol. Geotherm. Res. 201, 97-112. https://doi.org/10.1016/j.jvolgeores.2010.09.005

Gullikson, A. L., R. B. Anderson, Williams, R. M. E., 2016. Sinuous ridges in northwest Hellas, Mars. $47^{\text {th }}$ Lunar and Planetary Science, Houston, Texas, USA, Abstract \# 2376.

Gumbricht, T., McCarthy, J. \& McCarthy, T.S., 2004. Channels, wetlands and islands in the Okavango Delta, Botswana, and their relation to hydrological and sedimentological processes. Earth Surf. Proc. Land. 29, 15-29. https://doi.org/10.1002/esp.1008

Halevy, I., Head III, J. 2014. Episodic warming of early Mars by punctuated volcanism. Nature Geosci 7, 865-868 http://doi:10.1038/ngeo2293 
Hall, B.L., Hendy, C.H., Denton, G.H., 2006. Lake-ice conveyor deposits: Geomorphology, sedimentology, and importance in reconstructing the glacial history of the Dry Valleys. Geomorphology 75, 143-156. https://doi.org/10.1016/j.geomorph.2004.11.025

Hall, G.C., Kneeshaw, M., 1990. Yandicoogina - Marillana Pisolitic iron deposits. In Hughes, F.E (Editor), Geology of mineral deposits of Australia and Papua New Guinea. AusLMM, Melbourne, pp. 1581-1586.

Hayden, A.T., Lamb, M.P., Fischer, W.W., Ewing, R.C., McElory, B.J., Williams, R.M.E., 2019. Formation of sinuous ridges by inversion of river-channel belts in Utah, USA, with implications for Mars. Icarus, https://doi.org/10.1016/j.icarus.2019.04.019

Haynes, C.V., 1980. Geochronology of Wadi Tushka: lost tributary of the Nile. Science, 210 (4465), 68-71. https://doi.org/10.1126/science.210.4465.68

Hermelin, M., 2016. Landscapes and landforms of Colombia. Springer, 219p. https://doi.org/10.1007/978-3-319-11800-0

Higgins, J.M., 2000. Geologic road and trail guide to Snow Canyon State Park, Utah. Utah Geological Association Publication 29, 29p.

Higgins, J.M., Willies, G.C., 1995. Interim Geologic Map of the St. George Quadrangle, Washington County, Utah. Utah Geological Survey, Open-File Report 323, 45p.

Holm, D.A., 1960. Desert geomorphology in the Arabian Peninsula. Science, 132 (3437), 13691379. https://doi.org/10.1126/science.132.3437.1369

Hörner, N.G., 1932. Lop-Nor. Topographical and geological summary. Geografiska Annaler, 14, 297-321. http://www.jstor.org/stable/519598

Hou, B., Fabris, A.J., Keeling, J.L., Fairclough, M.C., 2007. Cenozoic paleochennel-hosted uranium and current exploration methods, South Australia. MESA Journal, 46, 34-39.

Hou, B., Zang, W., Fabris, A., Keeling, J., Stoian, L. and Fairclough, M. (compilers) 2007. Palaeodrainage and Tertiary Coastal Barrier of South Australia. CRC LEME, Geological Survey Branch, Primary Industries Resources South Australia. Digital Geological Map of South Australia, 1:2,000,000 Series 1st Edition. 
Howard, A. D., Moore, J. M., 2011. Late Hesperian to early Amazonian midlatitude Martian valleys: Evidence from Newton and Gorgonum basins. Journal of Geophysical Research 116, E05003, http://doi:10.1029/2010JE003782

Hughes, C. M., Cardenas, B. T., Goudge, T. A., \& Mohrig, D. 2019. Deltaic deposits indicative of a paleo- coastline at Aeolis Dorsa, Mars. Icarus, 317, 442- 453. https://doi.org/10.1016/j.icarus.2018.08.009

Hurowitz, J.A., Fischer, W.W., Tosca, N.J., Milliken, R.E., 2010. Origin of acidic surface waters and the evolution of atmospheric chemistry on early Mars. Nature Geoscience 3, 323-326. https://doi.org/10.1038/ngeo831

Husson, J.M., Peters, S.E., 2018. Nature of the sedimentary rock record and its implications for Earth system evolution. Emerging Topics in Life Sciences 2, 125-136. https://doi.org/10.1042/ETLS20170152

Irwin, R. P. III, K. W. Lewis, A. D. Howard, J. A. Grant, 2015. Paleohydrology of Eberswalde crater, Mars. Geomorphology 240, 83-101. https://doi.org/10.1016/j.geomorph.2014.10.012

Jacobsen, R. E., Burr, D. M., 2017. Dichotomies in the fluvial and alluvial fan deposits of the Aeolis Dorsa, Mars: implications for weathered sediment and paleoclimate. Geosphere, 13(6), 2154-2168. https://doi.org/10.1130/GES01330.1

Jerolmack, D. J., D. Mohrig, M. T. Zuber, S. Byrne, 2004. A minimum time for the formation of Holden northeast fan, Mars. Geophysical Research Letters 31, L21701. https://doi.org/10.1029/2004GL021326

Joyce, E.B., Webb, J.A. and Tidey, A. 1983. Silcrete in south central Victoria: composition, age and relationship to lava flows. Bureau of Mineral Resources Geology \& Geophysics Record 1983/27, 82-87.

Kar, A. 2011. Quaternary Geomorphic Processes and Landform Development in the Thar Desert of Rajasthan. In Bandyopadhyay, S. (Editor). Landforms Processes \& Environment Management acb publications, Kolkata, India, 223254.

Kargel, J.S., Storm, R.G., 1992. Ancient glaciation on Mars. Geology, 20, 3-7. https://doi.org/10.1130/0091-7613(1992)020<0003:AGOM>2.3.CO;2 
Kargel, J.S., Strom, R.G., 1991. Terrestrial glacial eskers: Analogs for martian sinuous ridges. 22nd Lunar Planet. Sci. Conference, 683-684.

Karlstrom, K.E., L.J. Crossey, E. Embid, R. Crow, M. Heizler, R. Hereford, L.S. Beard, J.W. Ricketts, S. Cather, Kelley, S. 2017. Cenozoic incision history of the Little Colorado River: Its role in carving Grand Canyon and onset of rapid incision in the past ca. $2 \mathrm{Ma}$ in the Colorado River System. Geosphere; 13 (1): 49-81. https://doi.org/10.1130/GES01304.1

Keller, S.M., Morgan, M.L., 2013. New palecurrent measurements in the late Eocene Castle Rock Conglomerates, east-central Colorado: Remapping the fluvial system. $125^{\text {th }}$ anniversary annual meeting \& Expo, paper No. 92-6.

Keller, S.M., Morgan, M.L., 2013. New palecurrent measurements in the late Eocene Castle Rock Conglomerates, east-central Colorado: Remapping the fluvial system. Geological Society of America Abstracts with Programs. Vol. 45, No. 7, p.241.

Keller, S.M., Morgan, M.L., 2016. Overview of the Eocene Castle Rock Conglomerate, eastcentral Colorado: Remapping the fluvial system, and implications for the history of the Colorado Piedmont and Front Range, in Keller, S.M., and Morgan, M.L., eds., Unfolding the Geology of the West: Geological Society of America Field Guide 44, p. 125-141, https://doi.org/10.1130/2016.0044(05)

King, L.C., 1942. South African Scenery: A textbook of geomorphology. Edinburgh, Oliver and Boyd, 379 p.

Kite, E. S., A. D. Howard, A. S. Lucas, J. C. Armstrong, O. Aharonson, Lamb, M. P., 2015. Stratigraphy of Aeolis Dorsa, Mars: Stratigraphic context of the great river deposits. Icarus 253, 223-242. https://doi.org/10.1016/j.icarus.2015.03.007

Kite, E.S., 2019. Geologic constraints on early Mars climate. Space Sci Rev, 215: 10. https://doi.org/10.1007/s11214-018-0575-5

Knepper, D.H., Jr., 2005, Bedrock erosion surface beneath the Rocky Flats alluvial fan, Jefferson and Boulder Counties, Colorado. Mountain Geologist, 42(1), 1-8.

Kocar, D., Benner, S.G., Fendorf, S. (2014). Deciphering and predicting spatial and temporal concentrations of arsenic within the Mekong Delta aquifer. Environmental Chemistry 11, 579-594. https://doi.org/10.1071/EN13244 
Lageson, D.R., Peters, S.G., Lahren, M.M., 2000. Great Basin and Sierra Nevada. Geological Society of America Field Guide 2, 430p. https://doi.org/10.1130/0-8137-0002-7

Lazear, G., Karlstrom, K., Aslan, A., Kelley, S., 2013. Denudation and flexural isostatic response of the Colorado Plateau and southern Rocky Mountains region since 10 Ma. Geosphere ; 9 (4): 792-814, https://doi.org/10.1130/GES00836.1

Le Deit, L., E. Hauber, F. Fueten, M. Pondrelli, A. P. Rossi, R. Jaumann (2013). Sequence of infilling events in Gale crater, Mars: Results from morphology, stratigraphy, and mineralogy. Journal of Geophysical Research Planets, 118, 2439-2473. https://doi.org/10.1002/2012JE004322

LeConte, J., 1880. The old river beds of California. American Journal of Science 19, 176-190. https://doi.org/10.2475/ajs.s3-19.111.176

LeConte, J., 1886. A post-Tertiary elevation of the Sierra Nevada shown by the river beds. American Journal of Science 32, 167-181. https://doi.org/10.2475/ajs.s3-32.189.167

Lefort, A., D. M. Burr, R. A. Beyer, A. D. Howard, 2012. Inverted fluvial features in the AeolisZephyria Plana, western Medusae Fossae Formation, Mars: Evidence for post-formation modification. Journal of Geophysical Research 117, E03007. https://doi.org/10.1029/2011JE004008

Lescinsky, D.T., Sisson, T.W., 1998. Ridge-forming, ice-bounded lava flows at Mount Rainier, Washington. Geology, 26, 351-354. https://doi.org/10.1130/00917613(1998)026<0351:RFIBLF>2.3.CO;2

Leverington, D. W., 2007. Was the Mangala Valles system incised by volcanic flows? Journal of Geophysical Research 112, E11005. https://doi.org/10.1029/2007JE002896

Leverington, D.W., 2007. Was the Mangala Valles system incised by volcanic flows? JGR Planets, https://doi.org/10.1029/2007JE002896

Lewis, K. W., Aharonson, O., 2006. Stratigraphic analysis of the distributary fan in Eberswalde crater using stereo imagery. Journal of Geophysical Research 111, E06001. https://doi.org/10.1029/2005JE002558 
Lindsey, D.A., and Van Gosen, B.S., 2010, Processes of terrace formation on the Piedmont of the Santa Cruz River valley during Quaternary time, Green Valley-Tubac area, southeastern Arizona: U.S. Geological Survey Scientific Investigations Report 2010-5028, 39 p. https://doi.org/10.3133/sir20105028

Lindsey, D.A., Langer, W.H., and Knepper, D.H., Jr., 2005. Stratigraphy, lithology, and sedimentary features of Quaternary alluvial deposits of the South Platte River and some of its tributaries east of the Front Range, Colorado: U.S. Geological Survey Professional Paper 1705,70 p. https://doi.org/10.3133/pp1705

Loizeau. D., N. Mangold, F. Poulet, J.-P. Bibring, A. Gendrin, V. Ansan, C. Gomez, B. Gondet, Y. Langevin, P. Masson, G. Neukum, 2007. Phyllosilicates in the Mawrth Vallis region of Mars. Journal of Geophysical Research 112, E08S08. https://doi.org/10.1029/2006JE002877

Loope, D., Kettler, R., Murray, K., Pederson, J., and Reiners, P., 2016. Sandstones and Utah's canyon country: Deposition, diagenesis, exhumation, and landscape evolution, inKeller, S.M., and Morgan, M.L., eds., Unfolding the Geology of the West: Geological Society of America Field Guide 44, p. 41-71, https://doi.org/10.1130/2016.0044(02)

Love, D.W., Seager, W.R., 1996. Fluvial fans and related basin deposits of the Mimbres drainage. New Mexico Geology 18, 81-92.

Lucchitta, B. K., 2005. Light layer and sinuous ridges on plateau near Juventae Chasma, Mars. 36 Lunar and Planetary Science, Houston, Texas, USA, abstract \#1500.

Luccihtta, I., Holm, F.R., Luccihtta, B.K., 2011. A Miocene river in northern Arizona and its implications for the Colorado River and Grand Canyon. GSA TODAY 21, https://doi.org/10.1130/G119A.1

MacLeod, W.N., 1966. The geology and iron deposits of the Hamersley Range area, Western Australia. Geol. Surv. West. Aust. Bull., 117.

Madof, A.S., Bertoni, C., Lofi, J., 2019. Discovery of vast fluvial deposits provides evidence for drawdown during the late Miocene Messinian Salinity Crisis. Geology, 47, 171-174. https://doi.org/10.1130/G45873.1 
Maizels, J., 1983. Paleovelocity and paleodischarge determination for coarse gravel deposits. In: Gregory, K.J. (Editor), Background to Paleohydrology - A Perspective. New York, John Wiley, 101-139.

Maizels, J., 1987. Plio-Pleistocene raised channel systems of the western Sharqiya (Wahiba), Oman. In: Frostick, L., and Reid, I. (Editors), Desert Sediments-Ancient and Modern. British Geological Society, Special Publication, 35, 31-50., https://doi.org/10.1144/GSL.SP.1987.035.01.04

Maizels, J., 1990. Raised channels as indicators of palaeohydrologic change-a case study from Oman. Palaeogeography, Palaeoclimatology, Palaeoecology, 76, 241-277. https://doi.org/10.1016/0031-0182(90)90115-N

Malin, M. C., Edgett, K. S., 2003. Evidence for persistent flow and aqueous sedimentation on early Mars. Science 302, 1931-1934. https://doi.org/10.1126/science.1090544

Malin, M. C., K. S. Edgett, B. A. Cantor, M. A. Caplinger, G. E. Danielson, E. H. Jensen, M. A. Ravine, J. L. Sandoval, K. D. Supulver, 2010. An overview of the 1985-2006 Mars Orbiter Camera science investigation. Mars 5, 1-60. https://doi.org/10.1555/mars.2010.0001

Mangold, N., C. Quantin, V. Ansan, C. Delacourt, P. Allemand, 2004. Evidence for precipitation on Mars from dendritic valleys in the Valles Marineris area. Science 305, 78-81. https://doi.org/10.1126/science.1097549

Mangold, N., E. S. Kite, M. G. Kleinhans, H. Newsom, V. Ansan, E. Hauber, E. Kraal, C. Quantin, K. Tanaka, 2012. The origin and timing of fluvial activity at Eberswalde crater, Mars. Icarus 220, 530-551. https://doi.org/10.1016/j.icarus.2012.05.02

Mangold, N., V. Ansan, Ph. Mason, C. Quantin, G. Neukum, 2008. Geomorphic study of fluvial landforms on the northern Valles Marineris plateau, Mars. Journal of Geophysical Research 113, E08009. https://doi.org/10.1029/2007JE002985

Marzo, G. A., T. L. Roush, N. L. Lanza, P. C. McGuire, H. E. Newsom, A. M. Ollila, S. M. Wiseman, 2009. Association of phyllosilicates and the inverted channel in Miyamoto crater, Mars. Geophysical Research Letters 36, L11204. https://doi.org/10.1029/2009GL038703 
Matsubara, Y., A. D. Howard, D. M. Burr, R. M.E. Williams, W. E. Dietrich, Moore, J. M., 2015. River meandering on Earth and Mars: A comparative study of Aeolis Dorsa meanders, Mars and possible terrestrial analogs of the Usuktuk River, AK, and the Quinn River, NV. Geomorphology 240, 102-120, https://doi.org/10.1016/j.geomorph.2014.08.031

Matter, A., Mahjoub, A., Neubert, E., Preusser, F., Schwalb, A., Szidat, S., Wulf, G., 2016. Reactivation of the Pleistocene trans-Arabian Wadi ad Dawasir fluvial system (Saudi Arabia) during the Holocene humid phase. Geomorphology 270, 88-101. https://doi.org/10.1016/j.geomorph.2016.07.013

Maxwell, T.A., Issawi, B., Haynes, C.V., 2010. Evidence for Pleistocene lakes in the Tushka region, south Egypt. Geology 38(12), 1135-1138. https://doi.org/10.1130/G31320.1

McCauley, J.F., Grolier, M.J., Breed, C.S., 1977. Yardangs of Peru and other desert regions. U.S. Geological Survey Interagency Report, Astrogeology 81, 177 p.

McDonald, E.V., McFadden, L.D., Wells, S.G., 2003. Regional response of alluvial fans to the Pleistocene-Holocene climatic transition, Mojave Desert, California. In Enzel, Y., Wells, S.G., Lancaster, N. (Eds.), Paleoenvironments and paleohydrology of the Mojave and southern Great Basin deserts. Geological Society of America Special Paper 368, 189-206. https://doi.org/10.1130/0-8137-2368-X.189

McNally, G.H., Wilson, I.R., 1996. Silcretes of the Mirackina palaeochannel, Arckaringa, South Australia. AGSO Journal of Australian Geology \& Geophysics. 16 (3). 295-301.

McQueen, K.G., Gonzalez, O.R., Roach, I.C., Pillans, B.J., Dunlap, W.J. and Smith, M.L., 2007. Landscape and regolith features related to Miocene leucitite lava flows, El Capitan northeast of Cobar, New South Wales. Australian Journal of Earth Sciences 54, 1-17. https://doi.org/10.1080/08120090600923311

Metz, J. M., J. P. Grotzinger, D. Mohrig, R. Milliken, B. Prather, C. Pirmez, A. S. McEwen, C. M. Weitz, 2009. Sublacustrine depositional fans in southwest Melas Chasma. Journal of Geophysical Research 114, E10002. https://doi.org/10.1029/2009JE003365

Michalski, J. R., E. Z. Noe Dobrea, 2007. Evidence for a sedimentary origin of clay minerals in the Mawrth Vallis region, Mars, Geology 35(10), 951-954. https://doi.org/10.1130/G23854A.1 
Migoń, P., 2004. Inverted relief. In: Goudie, A., Encyclopedia of Geomorphology, Routledge, London, 574. https://doi.org/10.4324/9780203381137

Miller, R.P., 1937. Drainage lines in bas-relief. Journal of Geology 45, 432-438. https://doi.org/10.1086/624550

Milliken, R. E., G. A. Swayze, R. E. Arvidson, J. L. Bishop, R. N. Clark, B. L. Ehlmann, R. O. Green, J. P. Grotzinger, R. V. Morris, S. L. Murchie, Weitz, C., 2008. Opaline silica in young deposits on Mars. Geology 36(11), 847-850. https://doi.org/10.1130/G24967A.1

Mohrig, D., Heller, P., Paola, C. and Lyons, W.J., 2000. Interpreting avulsion processes from ancient alluvial sequences: the Guadalope-Matarranya system (northern Spain) and Wasatch Formation (western Colorado). Geol. Soc. Am. Bull., 112, 1787-1803. https://doi.org/10.1130/0016-7606(2000)112<1787:IAPFAA>2.0.CO;2

Molina, A., M. A. de Pablo, E. Hauber, L. Le Deit, D. Fernández-Remolar, 2014. Geology of the Ariadnes Basin, NE Eridania quadrangle, Mars, 1:1Million. Journal of Maps 10(3), 487499. https://doi.org/10.1080/17445647.2014.888018

Moore, A.E., Blenkinsop, T., Cotterill, F.P.D., 2012. Dynamics evolution of the Zimbabwe watershed, central Zimbabwe. South African Journal of Geology 115, 553-562. https://doi.org/10.2113/gssajg.115.4.551

Moore, A.E., Cotterill, F.P.D., Broderick, T., Plowes, D., 2009. Landscape evolution in Zimbabwe from the Permian to present with implications for kimberlite prospecting. South African Journal of Geology 112, 65-88. https://doi.org/10.2113/gssajg.112.1.65

Moore, J. M., 1990. Nature of the mantling deposit in the heavily cratered terrain of northeastern Arabia, Mars. Journal of Geophysical Research 95(B9), 14,279-14,289. https://doi.org/10.1029/JB095iB09p14279

Moore, J. M., A. D. Howard, W. E. Dietrich, P. M., 2003. Martian layered fluvial deposits: Implications for Noachian climate scenarios. Geophysical Research Letters 30(24), 2292. https://doi.org/10.1029/2003GL019002

Moore, J. M., Howard, A. D., 2005. Large alluvial fans on Mars. Journal of Geophysical Research, 110, E04005, https://doi.org/10.1029/2004JE002352 
Morgan, A. M., A. D. Howard, D. E. J. Hobley, J. M. Moore, W. E. Dietrich, R. M. E. Williams, D. M. Burr, J. A. Grant, S. A. Wilson, Matsubara, Y., 2014. Sedimentology and climatic environment of alluvial fans in the Martian Saheki crater and a comparison with terrestrial fans in the Atacama Desert. Icarus 229, 131-156, https://doi.org/10.1016/j.icarus.2013.11.007

Morrison, R.B. Mifflin, M.D., 2000. Lake Tecopa and its environs: 2.5 million years of exposed history relevant to climate, groundwater, and erosion issues at the proposed nuclear waste repository at Yucca Mountain, Nevada. In D.R. Lageson, S. Peters, and M.M. Lahren, eds, Great Basin and Sierra Nevada: Geological Society of America Field Guide 2:355-382, https://doi.org/10.1130/0-8137-0002-7.355

Nash, D.J. and Shaw, P.A. 1998. Silica and carbonate relationships in silcrete-calcrete intergrade duricrusts from the Kalahari of Botswana and Namibia. Journal of African Earth Sciences 27(1), 11-25. https://doi.org/10.1016/S0899-5362(98)00043-8

Nash, D.J., Ullyott, J.S., 2007. Silcrete. In D.J. Nash \& S.J. McLaren (Eds.), Geochemical Sediments and Landscapes (pp. 95-148). Oxford: Blackwell's. https://doi.org/10.1002/9780470712917.ch4

Newsom, H.E., Lanza, N.L., Ollila, A.M., Wiseman, S.M., Rousch, T.L., Marzo, G.A., Tornabene, L.L., Okubo, C.H., Osterloo, M.M., Hamilton, V.E., Crumpler, L.S., 2010. Inverted channel deposits on the floor of Miyamoto crater, Mars. Icarus 205 (1):64-72. https://doi.org/10.1016/j.icarus.2009.03.030

Nicoll, K., 2004. Recent environmental change and prehistoric human activity in Egypt and Northern Sudan. Quaternary Science Reviews. 23 (5-6), 561-580. https://doi.org/10.1016/j.quascirev.2003.10.004

Niem, A.R. (1974). Wright's point, Harney County, Oregon, an example of inverted topography. The Ore Bin, 36 (3), 33-52. 
Noe Dobrea, E. Z., J. L. Bishop, N. K. McKeown, R. Fu, C. M. Rossi, J. R. Michalski, C. Heinlein, V. Hanus, F. Poulet, R. J. F. Mustard, S. Murchie, A. S. McEwen, G. Swayze, J.-P. Bibring, E. Malaret, C. Hash, 2010. Mineralogy and stratigraphy of phyllosilicate-bearing and dark mantling units in the greater Mawrth Vallis/west Arabia Terra area: Constraints on geological origin. Journal of Geophysical Research 115, E00D19. https://doi.org/10.1029/2009JE003351

Ollier, C.D., Chan, R.A., Craig, M.A., Gibson, D.L., 1988. Aspects of landscape history and regolith in the Kalgoorlie region. Western Australia. BMR J. Aust. Geol. Geophys., 10: 309321.

Ollier, C.D., Sheth, H.C., 2008. The High Deccan duricrusts of India and their significance for the 'laterite' issue. Journal of Earth System Science, 117: 537. https://doi.org/10.1007/s12040$\underline{008-0051-9}$

Osterloo, M. M., F. S. Anderson, V. E. Hamilton, Hynek, B. M., 2010. Geologic context of proposed chloride-bearing materials on Mars. Journal of Geophysical Research 115, E10012. https://doi.org/10.1029/2010JE003613

Oviatt, C.G., Madsen, D.B., Schmitt, D.N., 2003. Late Pleistocene and early Holocene rivers and wetlands in the Bonneville basin of western North America. Quaternary Research, 60, 200210. https://doi.org/10.1016/S0033-5894(03)00084-X

Padgett, G.V., Ehrlich, R., 1976. Paleohydrologic analysis of a late Carboniferous fluvial system, southern Morocco. Geological Society of America, Bulletin 87, 1101-1104. https://doi.org/10.1130/0016-7606(1976)87<1101:PAOALC>2.0.CO;2

Pain, C. F., Clarke, J. D. A. and Thomas, M., 2007. Inversion of relief on Mars. Icarus 190(2), 478-491. https://doi.org/10.1016/j.icarus.2007.03.017

Pain, C.F. and Ollier, C.D. 1992. Ferricrete in Cape York Peninsula, North Queensland. BMR Journal of Australian Geology and Geophysics 13, 207-212.

Pain, C.F., Ollier, C.D., 1995. Inversion of relief - a component of landscape evolution. Geomorphology, 12 (2), 151-165. https://doi.org/10.1016/0169-555X(94)00084-5 
Pain, C.F., Wilford, J.R. and Dohrenwend, J.C. 1994. Regolith-landforms of the Ebagoola 1:250,000 sheet area, (SD54-12), North Queensland. AGSO Record 1994/7, 38pp, 1:250,000 map.

Pajola, M., S. Rossato, J. Carter, E. Baratti, R. Pozzobon, M. S. Erculiani, M. Coradini, K. McBride, 2016. Eridania Basin: An ancient paleolake floor as the next landing site for the Mars 2020 rover. Icarus 275, 163-182. https://doi.org/10.1016/j.icarus.2016.03.029

Palucis, M. C., W. E. Dietrich, A. G. Hayes, R. M.E. Williams, S. Gupta, N. Mangold, H. Newsom, C. Hardgrove, F. Calef III, Sumner, D. Y., 2014. The origin and evolution of the Peace Vallis fan system that drains to the Curiosity landing area, Gale crater, Mars. Journal of Geophysical Research Planets 119, 705-728. https://doi.org/10.1002/2013JE004583

Pondrelli, M., A. P. Rossi, L. Marinangeli, E. Hauber, K. Gwinner, A. Baliva, Di Lorenzo, S., 2008. Evolution and depositional environments of the Eberswalde fan delta, Mars. Icarus 197, 429-451. https://doi.org/10.1016/j.icarus.2008.05.018

Pondrelli, M., A. P. Rossi, T. Platz, A. Ivanov, L. Marinangeli, Baliva, A., 2011. Geological, geomorphological, facies and allostratigraphic maps of the Eberswalde fan delta. Planetary and Space Science 59, 1166-1178. https://doi.org/10.1016/j.pss.2010.10.009

Price, R.J., 1966. Eskers near the casement glacier, Alaska. Geografiska Annaler: Series A, Physical Geography 8:3, 111-125. https://doi.org/10.1080/04353676.1966.11879733

Renault, R.W., Owen, R.B., Jones, B., Tiercelin, J.-J., Tarits, C., Ego, J.K., Konhauser, K.O., 2013. Impact of lake-level changes on the formation of thermogene travertine in continental rifts: evidence from Lake Bogoria, Kenya Rift Valley. Sedimentology 60, 428-468. https://doi.org/10.1111/j.1365-3091.2012.01347.x

Rhodes, D. D., 1980. Exhumed topography - a case study of the Stanislaus Table Mountain, California. Reports of Planetary Geology Program - 1980, NASA Technical Memorandum 82385, pp. 397-399.

Rhodes, D.D., 1987. Table Mountain of Calaveras and Tuolumne Counties, California. In Hill, M.L. (Ed.), DNAG Centennial Field Guides, Cordilleran Section of the Geological Society of America, 269-272. https://doi.org/10.1130/0-8137-5401-1.269 
Rice, J. W. Jr., J. D. Mollard, 1994. Analogs and interpretations for the Martian thumbprint terrain and sinuous ridges. 25 Lunar and Planetary Science, Houston, Texas, USA, 1127-1128.

Rice, M. S., J. F. Bell III, S. Gupta, N. H. Warner, K. Goddard, R. B. Anderson, 2013. A detailed geologic characterization of Eberswalde crater, Mars. Mars, 15-59. https://doi.org/10.1555/mars.2013.0002

Ristorcelli, S., Ronning, P., Tucker, P., Guido. D., 2013. Technical Report on the Pingüino Project Santa Cruz Province, Argentina. Argentex Mining Corporation, 141p.

Sandford, K.S., Arkell, W.J., 1933. Paleolithic man and the Nile-Fayum divide: A study of the region during Pliocene and Pleistocene times, Oriental Institute Publications 17, University of Chicago Press, 92 p.

Sandoval, M.M., 2007. Quaternary incision history of the Black Canyon of the Gunnison, Colorado. Dissertation, University of New Mexico, 96p. Retrieved (DATE) from https://digitalrepository.unm.edu/eps_etds/77

Schon, S.C., Head III, J.W., Fassett, C.I., 2012. An overfilled lacustrine system and progradational delta in Jezero crater, Mars: Implications for Noachian climate. Planetary and Space Science, 67 (1), 28-45. https://doi.org/10.1016/j.pss.2012.02.003

Schuster, M., Roquin, C., Duringer, P., Brunet, M., Caugy, M., Fontugne, M., Mackaye, H.T., Vignaud, P., Chienne, J.F., 2005. Holocene Lake Mega-Chad paleoshorelines from space. Quaternary Science $\quad$ Reviews, 24, 1821-1827. https://doi.org/10.1016/j.quascirev.2005.02.001

Shaw, A.I., 2009. The characterization of calcrete based on its environmental settings within selected regions of the Kalahari, South Africa, $\mathrm{PhD}$ thesis, University of Oxford, $409 \mathrm{p}$.

Shreve, R.L., 1985. Eskers characteristics in terms of glacier physics, Katahdin esker system, Maine. Geological Society of America Bulletin 96, 639-646. https://doi.org/10.1130/00167606(1985)96<639:ECITOG>2.0.CO;2

Sinha, R. K., Murty, S. V. S., 2015. Amazonian modification of Moreux crater: Record of recent and episodic glaciation in the Protonilus Mensae region of Mars. Icarus 245, 122-144. https://doi.org/10.1016/j.icarus.2014.09.028 
Smith, R.M.H., 1987. Morphology and depositional history of exhumed Permian point bars in the southwestern Karroo, South Africa. Journal of Sedimentary Petrology 57, 19-29. https://doi.org/10.1306/212F8A8F-2B24-11D7-8648000102C1865D

Smith, R.M.H., Sidor, C.A., Tabor, N.J., Sebastien, J.S., 2015. Sedimentology and vertebrate taphonomy of the Moradi Formation of northern Niger: A Permian wet desert in the tropics of Pangaea. Palaeogeography, Palaeoclimatology, Palaeoecology, https://doi.org/10.1016/j.palaeo.2015.08.032

Suneson, N.H., Luza, K.V., 1999. A field trip guide to the geology of the Black Mesa State Park area, Cimarron County, Oklahoma. Oklahoma Geological Survey, 52p.

Tanaka, K.L., Chapman, M.G., 1990. The relation of catastrophic flooding of Mangala Valles, Mars, to faulting of Memnonia Fossae and Tharsis Volcanism. JGR Planets, https://doi.org/10.1029/JB095iB09p14315

Taylor, G. and Eggleton, R.A. 2017. Silcrete: an Australian perspective. Australian Journal of Earth Sciences 64, 987-1016. https://doi.org/10.1080/08120099.2017.1318167

Taylor, J. M., 1950. Pore space reduction in sandstone. American Association of Petroleum Geologists Bulletin, 34, 710-716.

Teilhard de Chardin, P, Young, C.C., 1935. The Cenozoic Sequence in the Yangtze Valley. Journal of the Geological Society of China, https://doi.org/10.1111/j.1755$\underline{6724.1935 . m p 14002003 . x}$

Thiry, M., Milnes, A., 2017. Silcretes: Insights into the occurrences and formation of materials sourced for stone tool making. Journal of Archaeological Science: Reports 15, 500-513. https://doi.org/10.1016/j.jasrep.2016.08.015

Thomson, B.J., Bridges, N.T., Milliken, R., Baldridge, A., Hook, S.J., Crowley, J.K.,Marion, G.M., de Souza Filho, C.R., Brown, A.J., Weitz, C.M., 2011. Constraints on the origin and evolution of the layered mount in Gale Crater, Mars, using Mars Reconnaissance Orbiter data. Icarus 214, 413-432. https://doi.org/10.1016/j.icarus.2011.05.002 
Thouret, J.C., Cantagrel, J., Robin, C., Murica, A., Salinas, A., Cepeda, H., 1995. Quaternary eruptive history and hazard-zone model at Nevado del Tolima and Cerro Machin volcanoes, Colombia. Journal of Volcanology and Geothermal Research 66, 397-426. https://doi.org/10.1016/0377-0273(94)00073-P

Twidale, C.R., Horwitz, R.C., Campbell, E.M., 1985. Hamersley landscapes of the northwest of Western Australia. Rev. Geol. Dynam. Geogr. Phys., 26(3): 173-186.

Vaucher, J., et al., 2009. The volcanic history of central Elysium Planitia: Implications for martian magmatism, Icarus 204, 418-442. http://doi.org/10.1016/j.icarus.2009.06.032

Verrecchia, E.P. 2007. Lacustrine and palustrine geochemical sediments. In Nash, D.J. and McLaren, S.J. (Editors). Geochemical Sediments and Landscapes. Blackwell Publishing, Oxford, 298-329. https://doi.org/10.1002/9780470712917.ch9

Wang, J., Bhattacharya, J., 2018. Plan-view paleochannel reconstruction of amalgamated meaner belts, Cretaceous Ferron Sandstone, Notom Delta, South-Centeral Utah, USA. Journal of Sedimentary Research, 88, 58-74. https://doi.org/10.2110/jsr.2017.77

Wang, Z-T., Z-P. Lai, J-J. Qu, 2015. Inverted relief landforms in the Kumtagh Desert of northwestern China: A mechanism to estimate wind erosion rates. Geological Journal, https://doi.org/10.1002/gj.2739

Weitz, C. M., R. E. Milliken, J. A. Grant, A. S. McEwen, R. M. E. Williams, Bishop, J. L. 2008. Light-toned strata and inverted channels adjacent to Juventae and Ganges chasmata, Mars. Geophysical Research Letters 35, L19202. https://doi.org/10.1029/2008GL035317

Weitz, C. M., R. E. Milliken, J. A. Grant, A. S. McEwen, R. M. E. Williams, J. L. Bishop, Thomson B. J., 2010. Mars Reconnaissance Orbiter observations of light-toned layered deposits and associated fluvial landforms on the plateaus adjacent to Valles Marineris. Icarus 205, 73102. https://doi.org/10.1016/i.icarus.2009.04.017

Whitney, J.D., 1865. Report of Progress and Synopsis of the Field Work From 1860 to 1864. Geological Survey of California, Vol. 1, Philadelphia, 498p.

Wiggs, J.F., Livingstone, I., 2003. Processes of wind erosion. In Goudie, Encyclopedia of Geomorphology, Routledge, p. 40. 
William, R.M.E., Irwin III, R.P., 2009. Morphology of lava-capped inverted valleys near St. George, Utah: Analogs for martian sinuous ridges. 40 ${ }^{\text {th }}$ Lunar and Planetary Science Conference, \#2413.

Williams F.M., 2016. The Southeastern Highlands and the Ogaden. In: Understanding Ethiopia. GeoGuide. Springer, Cham, https://doi.org/10.1007/978-3-319-02180-5_15

Williams R. M. E., Edgett, K. S., 2005. Valleys in the martian rock record. $36^{\text {th }}$ Lunar and Planetary Science, Houston, Texas, USA, abstract \#1099.

Williams, R. M. E., 2013. Upside down rivers - Fluvial pathways on Earth and Mars, F\&M Scientist 1, 145-166, Franklin and Marshall College, Lancaster, Pennsylvania, USA.

Williams, R. M. E., Chidsey Jr, T. C., Eby, D. E., 2007. Exhumed paleochannels in central Utah Analogs for raised curvilinear features on Mars, In: G. C. Willis, M. D. Hylland, D. L. Clark, T. C. Chidsey Jr. (editors), Central Utah - Diverse geology of a dynamic landscape, Utah Geological Association Publication 36, 220-235, Salt Lake City, Utah, USA.

Williams, R. M. E., Chuang , F. C., 2012. Mapping of sinuous ridges in Oxia Palus, Mars: New insight into the aqueous record, 43 Lunar and Planetary Science, Houston, Texas, USA, abstract \#2156.

Williams, R.M., Irwin III, R.P., Burr, D.M., Harrison, T. and McClelland, P. 2013. Variability in Martian sinuous ridge form: Case study of Aeolis Serpens in the Aeolis Dorsa, Mars, and insight from the Mirackina paleoriver, South Australia. Icarus 225, 308-324.

Williams, R.M.E., 2007. Global spatial distribution of raised curvilinear features on Mars. Lunar Planet. Sci. Conf. 38 ${ }^{\text {th }}$, Abstract \# 1821.

Williams, R.M.E., 2009. Morphology of lava-capped inverted valleys near St. George, Utah: Analogs for martian sinuous ridges. 40th Lunar and Planetary Science Conference, \#2413.

Williams, R.M.E., Irwin, R.P. III, Burr, D.M., Harrison, T., McClelland, P., 2013. Variability in martian sinuous ridge form: Case study of Aeolis Serpens in the Aeolis Dorsa, Mars, and insight from the Mirackina paleoriver, South Australia. Icarus 225, 308-324. https://doi.org/10.1016/j.icarus.2013.03.016 
Williams, R.M.E., Irwin, R.P., Zimbelman, J.R., 2009. Evaluation of paleohydrologic models for terrestrial inverted channels: Implications for application to Martian sinuous ridges. Geomorphology, 107, 300-315. https://doi.org/10.1016/j.geomorph.2008.12.015

Williams, R.M.E., Moersch, J.E., Fergason, R.L., 2018. Thermophysical Properties of Martian Fluvial Sinuous Ridges: Inferences on "Inverted Channel" Induration Agent. Earth and Space Science, 5, 516-528. https://doi.org/10.1029/2018EA000402

Williams, R.M.E., R.P. Irwin III, J.R. Zimbelman, T.C. Chidsey Jr., Eby, D.E., 2011. Field guide to exhumed paleochannels near Green River, Utah: Terrestrial analogs for sinuous ridges on Mars, in Analogs for Planetary Exploration, edited by W. B. Garry and J. E. Bleacher, Geological Society of America Special Papers 483, 483-505. https://doi.org/10.1130/2011.2483(29)

Wilson, S. A., A. D. Howard, J. M. Moore, J. A. Grant (2016). A cold-wet mid-latitude environment on Mars during the Hesperian-Amazonian transition: Evidence from northern Arabia valleys and paleolakes. Journal of Geophysical Research Planets, http://doi:10.1002/2016JE005052

Wiseman, S. M., R. E. Arvidson, R. V. Morris, F. Poulet, S. L. Murchie, F. P. Seelos, J. L. Bishop, J. C. Andrews-Hanna, D. Des Marais, Griffes, J.L., 2010. Spectral and stratigraphic mapping of hydrated sulfate and phyllosilicate-bearing deposits in northern Sinus Meridiani, Mars, J. Geophys. Res. Planets 115, E00D18. https://doi.org/10.1029/2009JE003354

Wood, L. J. (2006). Quantitative geomorphology of the Mars Eberswalde delta. Geological Society of America Bulletin 118(5), 557-566. doi:10.1130/B25822.1

Worden, R. H., \& Burley, S. D., 2003. Sandstone diagenesis: From sand to stone. In S. D. Burley \& R. H. Worden (Eds.), Clastic diagenesis: Recent and ancient: International Association of Sedimentologists (pp. 3-44). Oxford: Blackwell. https://doi.org/10.1002/9781444304459.ch

Wright, H.E., Jr., 1958. An extinct wadi system in the Syrian Desert. Journal of Research Council of Israel, 7G, 53-59.

Wright, V.P., 2007. Calcrete. In D.J. Nash \& S.J. McLaren (Eds.), Geochemical Sediments and Landscapes (pp. 10-45). Oxford: Blackwell's. https://doi.org/10.1002/9780470712917.ch2 
Zabrusky, K., Andrews-Hanna, J.C., Wiseman, S.M., 2012. Reconstructing the distribution and depositional history of the sedimentary deposits of Arabia terra, Mars. Icarus 220(2), 311330. https://doi.org/10.1016/j.icarus.2012.05.007

Zabrusky, K., J. C. Andrews-Hanna, S. M. Wiseman (2012). Reconstructing the distribution and depositional history oft the sedimentary deposits of Arabia Terra, Mars, Icarus 220, 311330. https://doi.org/10.1016/j.icarus.2012.05.007

Zaki, A. S., Giegengack, R., 2016. Inverted topography in the southeastern part of the Western Desert of Egypt. Journal of African Earth Sciences 121, 56-61. https://doi.org/10.1016/j.jafrearsci.2016.05.020

Zaki, A.S., Edgett, K.S., Gupta, S., Thomas, N., Cremonese, G., Grindrod, P., Roige, M., Watkins, S., Castelltort, S., 2019. Inverted fluvial networks in the Antoniadi crater, Mars: A sedimentological and paleohydrological investigation. The EPSC-DPS Joint Meeting, Geneva, Vol. 13, EPSC-DPS2019-244-1.

Zaki, A.S., Giegengack, R., Castelltort, S., 2020. Inverted channels in the Eastern Saharadistribution, formation, and interpretation to enable reconstruction of paleodrainage networks, In: Herget J., Fontana A. (eds) Palaeohydrology. Geography of the Physical Environment. Springer, Cham. https://doi.org/10.1007/978-3-030-23315-0_6

Zaki, A.S., Pain, C., Edgett, K.E., Giegengack, R., 2018. Inverted stream channels in the Western Desert of Egypt: synergistic remote, field observations and laboratory analysis on Earth with application to Mars. Icarus 309, 105-124. https://doi.org/10.1016/j.icarus.2018.03.001

Zeegers, H., Lecomte, P., 1992. Seasonally humid tropical terrains (savannas). C.R.M. Butt, H. Zeegers (Eds.), Handbook of Exploration Geochemistry, 4. Regolith Exploration Geochemistry in Tropical and Subtropical Terrains, Elsevier, Amsterdam (1992), 203-240. https://doi.org/10.1016/B978-0-444-89095-5.50017-1

Zhao, J., J. Huang, L. Xiao, 2015. Characteristics and origin of sinuous ridges in Solis Planum, Mars. 46 Lunar and Planetary Science, Houston, Texas, USA, abstract \#1897

Zimbelman, J.R., Griffin, L.J., 2010. HiRISE images of yardangs and sinuous ridges in the lower member of the Medusae Fossae Formation, Mars. Icarus, 205, 198-210. https://doi.org/10.1016/j.icarus.2009.04.003 
Table 1 shows research since 1999 (data from orbiters Mars Global Surveyor, Mars Odyssey, Mars Express, Mars Reconnaissance Orbiter, CaSSIS - ExoMars Trace Gas Orbiter) focused on studies of landforms interpreted to be the product of erosional inversion of channels and other landforms on Mars.

\begin{tabular}{|c|c|c|}
\hline Location & Origin & References \\
\hline Eberswalde crater & Fluvial and deltaic & $\begin{array}{l}\text { Malin and Edgett, 2003; Moore et al., 2003; Jerolmak et al., 2004; } \\
\text { Bhattacharya et al., 2005; Lewis and Aharonson, 2006; Wood, } \\
\text { 2006; Pondrelli et al., 2008; Pondrelli et al., 2011; Mangold et al., } \\
\text { 2012; Rice et al., 2013; Irwin et al., } 2015\end{array}$ \\
\hline $\begin{array}{l}\text { Aeolis and Zephyria } \\
\text { regions }\end{array}$ & $\begin{array}{l}\text { Curvilinear ridges interpreted to } \\
\text { have fluvial origins, including } \\
\text { contributory and distributary } \\
\text { systems }\end{array}$ & $\begin{array}{l}\text { Edgett and Williams, 2004; Williams and Edgett, 2005; Pain et al., } \\
\text { 2007; Burr et al., 2009; Burr et al., 2010; Zimbelman and Griffin, } \\
\text { 2010; Lefort et al., 2012; DiBiase et al., 2013; Williams et al., } \\
\text { 2013b; Kite et al., 2015; Matsubara et al., 2015; Jacobsen and Burr, } \\
\text { 2017; Di Pietro et al., 2018; Williams et al., 2018; Hughes et al., } \\
\text { 2018 }\end{array}$ \\
\hline $\begin{array}{l}\text { Uplands west of Juventae } \\
\text { Chasma and adjacent to } \\
\text { chasms in the Valles } \\
\text { Marineris region }\end{array}$ & $\begin{array}{l}\text { Fine-scale and larger curvilinear } \\
\text { ridge networks }\end{array}$ & $\begin{array}{l}\text { Mangold et al. 2004; Lucchitta, 2005; Pain et al., 2007; Mangold et } \\
\text { al., 2008; Milliken et al., 2008; Weitz et al., 2008; Malin et al., } \\
\text { 2010; Weitz et al., } 2010 \text {; Williams et al., } 2018\end{array}$ \\
\hline Gale Crater & $\begin{array}{l}\text { Inverted channels and sediment } \\
\text { fans exhibiting inverted channel } \\
\text { elements }\end{array}$ & $\begin{array}{l}\text { Anderson and Bell, 2010; Thomson et al., 2011; LeDeit et al., 2013; } \\
\text { Palucis et al., } 2014\end{array}$ \\
\hline Mangala valles & Volcanic inverted channels & Tanaka and Chapman, 1990; Leverington, 2007 \\
\hline Western Arabia Terra & Inverted channel forms & $\begin{array}{l}\text { Williams and Chuang, 2012; Williams 2013; Balme et al., 2015; } \\
\text { Williams et al., } 2018\end{array}$ \\
\hline Sinus Meridiani & Inverted channel forms & $\begin{array}{l}\text { Edgett, 2005; Edgett et al., 2008; Marzo et al., 2009; Newsom et al., } \\
2010\end{array}$ \\
\hline Mawrth Vallis & Inverted channel forms & $\begin{array}{l}\text { Loizeau et al., 2007; Michalski and Noe Dobrea, 2007; Noe Dobrea } \\
\text { et al., 2010; Edgett and Saper, 2013a }\end{array}$ \\
\hline $\begin{array}{l}\text { Central and eastern } \\
\text { Arabia Terra }\end{array}$ & Inverted channel forms & $\begin{array}{l}\text { Moore, 1990; Grant and Schultz, 1990; Pain et al., 2007; Fassett and } \\
\text { Head, 2007; Davis et al., 2016; Wilson et al., 2016; Davis et al., } \\
\text { 2019; Day et al., } 2019\end{array}$ \\
\hline
\end{tabular}




\begin{tabular}{|c|c|c|}
\hline Moreux crater & Inverted channel forms & $\begin{array}{l}\text { Rice and Mollard, 1994; Sinha and Murty, 2015; Osterloo et al., } \\
\text { 2010; Howard and Moore, } 2011\end{array}$ \\
\hline $\begin{array}{l}\text { Xanthe Terra and } \\
\text { southern Chryse Planitia }\end{array}$ & Inverted channel forms & Edgett and Saper 2013 \\
\hline $\begin{array}{l}\text { Thaumasia-Solis Planum } \\
\text { region }\end{array}$ & Inverted channel forms & $\begin{array}{l}\text { Edgett et al., 2008; Zhao et al., 2015; Rhodes, 1980; Chapman and } \\
\text { Tanaka, 1993; Leverington, } 2007\end{array}$ \\
\hline $\begin{array}{l}\text { Eridania and Ariadnes } \\
\text { Basin region }\end{array}$ & Inverted channel forms & Molina et al., 2014; Pajola et al. 2016 \\
\hline Dorsa Argentea & Inverted fluvial channels & Fastook et al., 2012; Kargel, 1993; Bleacher et al., 2003 \\
\hline Hadriacus Palus & Inverted channel forms & Fortezzo, 2013 \\
\hline Hellas Planitia & Inverted channel forms & Bernhardt et al., 2016 \\
\hline Margaritifer Terra & Inverted channel forms & Williams et al., 2018 \\
\hline Ganges Chasma & Inverted channel forms & Williams et al., 2018 \\
\hline Hypanis Valles & $\begin{array}{l}\text { Inverted channel and deltaic } \\
\text { forms }\end{array}$ & Williams et al., 2018; Fawdon et al., 2018 ; Adler et al., 2019 \\
\hline Antoniadi Crater & Branched inverted channels & Davis et al., 2016; Zaki et al., 2018 ; Zaki et al., 2020 \\
\hline Terby Crater & Inverted channels & Ansan et al., 2011 \\
\hline Jezro crater & Deltaic deposits & e.g, Fassett and Head, 2005; Schon et al., 2012; Goudge et al., 2018 \\
\hline Global distribution & fluvial sinuous ridges & Williams et al., 2007; Dickson et al., 2019 \\
\hline Various & $\begin{array}{l}\text { Fan-shaped forms interpreted as } \\
\text { alluvial or deltaic deposits } \\
\text { include landforms interpreted by } \\
\text { some investigators as inverted } \\
\text { channels }\end{array}$ & $\begin{array}{l}\text { Moore and Howard, 2005; Fassett and Head, 2005; Metz et al., } \\
\text { 2009; Williams et al., 2011; Grant and Wilson, 2012; Morgan et al., } \\
\text { 2014; Gullikson et al., 2016; Cowart et al., } 2019\end{array}$ \\
\hline Various & $\begin{array}{l}\text { Inverted depressions (craters and } \\
\text { troughs) }\end{array}$ & $\begin{array}{l}\text { Craddock and Maxwell, 1990; Loizeau et al., 2007; Pain et al., } \\
\text { 2007; Fassett and Head, 2007; Noe Dobrea et al., 2010; Zabrusky et } \\
\text { al., 2012; Bernhardt et al., } 2016\end{array}$ \\
\hline
\end{tabular}


Table 2 shows the documented inverted-channel sites, used terms, and their relative absolute age on Earth

\begin{tabular}{|c|c|c|c|c|c|c|c|}
\hline \# & Country & area & Used term & Process & Age range & Climatic zone & Reference \\
\hline \multicolumn{8}{|c|}{ North America } \\
\hline 1 & USA & $\begin{array}{l}\text { Sierra Nevada, } \\
\text { CA }\end{array}$ & River beds & Volcanism & $9 \mathrm{Ma}$ & Subtropical & $\begin{array}{l}\text { (Whitney, } \\
\text { 1865; Le } \\
\text { conte, 1880; } \\
\text { 1886; Rhodes, } \\
\text { 1980, 1987; } \\
\text { Burr and } \\
\text { Williams, } \\
\text { 2009) }\end{array}$ \\
\hline 2 & & Utah & $\begin{array}{l}\text { Exhumed } \\
\text { paleochannels; } \\
\text { inverted } \\
\text { channels }\end{array}$ & $\begin{array}{l}\text { Channel fill } \\
\text { lithification }\end{array}$ & $\begin{array}{l}\text { Late Jurassic and } \\
\text { Early Cretaceous } \\
\text { and eroded 5.6 Ma }\end{array}$ & Subtropical & $\begin{array}{l}\text { Derr, 1974; } \\
\text { Harris, 1980; } \\
\text { Higgins and } \\
\text { Willies, 1995; } \\
\text { Williams et } \\
\text { al., 2007; } \\
\text { Williams et } \\
\text { al., 2011; } \\
\text { Clarke and } \\
\text { Stoker, 2011; } \\
\text { Cardenas et } \\
\text { al., 2019) }\end{array}$ \\
\hline 3 & & $\begin{array}{l}\text { Great Salt } \\
\text { Lake Desert }\end{array}$ & $\begin{array}{l}\text { Inverted } \\
\text { topography; } \\
\text { inverted gravel } \\
\text { channels }\end{array}$ & $\begin{array}{l}\text { Channel fill } \\
\text { cementation; } \\
\text { surface } \\
\text { armouring }\end{array}$ & $\begin{array}{l}11.9-10.5 \mathrm{ka} \\
\text { (C14) }\end{array}$ & Subtropical & $\begin{array}{l}\text { (Oviatt et al., } \\
\text { 2003) }\end{array}$ \\
\hline 4 & & $\begin{array}{l}\text { Northern } \\
\text { Arizona }\end{array}$ & Inverted relief & $\begin{array}{l}\text { Channel fill } \\
\text { cementation } \\
\text { (calcrete) }\end{array}$ & Late Miocene & Subtropical & $\begin{array}{l}\text { Lucchitta et } \\
\text { al., } 2011\end{array}$ \\
\hline
\end{tabular}




\begin{tabular}{|c|c|c|c|c|c|c|}
\hline 5 & Oregon & $\begin{array}{l}\text { Inverted } \\
\text { topography }\end{array}$ & Volcanism & $?$ & Temperate & Niem, 1974 \\
\hline 6 & $\begin{array}{l}\text { Near the Little } \\
\text { Colorado } \\
\text { River }\end{array}$ & $\begin{array}{l}\text { Basaltic } \\
\text { sandstone ridge }\end{array}$ & Volcanism & $?$ & Subtropical & Colton, 1937 \\
\hline 7 & $\begin{array}{l}\text { East-central } \\
\text { Colorado }\end{array}$ & $\begin{array}{l}\text { Inverted } \\
\text { topography }\end{array}$ & $\begin{array}{l}\text { Channel fill } \\
\text { cementation }\end{array}$ & Late Eocene & Subtropical & $\begin{array}{l}\text { (Keller and } \\
\text { Morgan, 2013, } \\
\text { 2016) }\end{array}$ \\
\hline 8 & $\begin{array}{l}\text { Mount } \\
\text { Rainier, } \\
\text { Washington }\end{array}$ & $\begin{array}{l}\text { Inverted } \\
\text { topography }\end{array}$ & Volcanism & $\begin{array}{l}87 \pm 5 \mathrm{ka}, 91 \pm 6 \mathrm{ka} \\
93 \pm 7 \mathrm{ka}, \text { and } 105 \pm \\
9 \mathrm{ka}\end{array}$ & Temperate & $\begin{array}{l}\text { Lescinsky and } \\
\text { Sisson, } 1998\end{array}$ \\
\hline 9 & $\begin{array}{l}\text { Lewis and } \\
\text { Yakima } \\
\text { Counties, } \\
\text { Washington }\end{array}$ & $\begin{array}{l}\text { Inverted } \\
\text { topography }\end{array}$ & Volcanism & Late Pliocene & Temperate & $\begin{array}{l}\text { (Church et al., } \\
\text { 1983) }\end{array}$ \\
\hline 10 & $\begin{array}{l}\text { Northwestern } \\
\text { Nebraska }\end{array}$ & $\begin{array}{l}\text { Inverted } \\
\text { topography }\end{array}$ & $\begin{array}{l}\text { Channel fill } \\
\text { cementation; } \\
\text { surface } \\
\text { armouring } \\
\end{array}$ & $?$ & Temperate & $\begin{array}{l}\text { Diffendal, } \\
1994\end{array}$ \\
\hline 11 & $\begin{array}{l}\text { New Mexico, } \\
\text { USA }\end{array}$ & $\begin{array}{l}\text { Inverted } \\
\text { topography }\end{array}$ & Volcanism & Pliocene & Subtropical & $\begin{array}{l}\text { Channer et al., } \\
2015\end{array}$ \\
\hline 12 & $\begin{array}{l}\text { Cimarron } \\
\text { County, } \\
\text { Oklahoma } \\
\end{array}$ & $\begin{array}{l}\text { Inversion of } \\
\text { relief }\end{array}$ & \begin{tabular}{|l} 
Volcanism \\
\end{tabular} & Pliocene & Subtropical & $\begin{array}{l}\text { Suneson and } \\
\text { Luza, } 1999\end{array}$ \\
\hline 13 & $\begin{array}{l}\text { Colorado } \\
\text { Plateau }\end{array}$ & $\begin{array}{l}\text { Inverted } \\
\text { topography }\end{array}$ & Volcanism & Miocene & Subtropical & $\begin{array}{l}\text { Lazear et al., } \\
2013\end{array}$ \\
\hline 14 & $\begin{array}{l}\text { Mimbres } \\
\text { drainage, New } \\
\text { Mexico }\end{array}$ & $\begin{array}{l}\text { Inverted } \\
\text { topography }\end{array}$ & $\begin{array}{l}\text { Channel fill } \\
\text { cementation; } \\
\text { surface } \\
\text { armouring } \\
\end{array}$ & $\begin{array}{l}\text { Pleistocene and } \\
\text { Holocene }\end{array}$ & Subtropical & $\begin{array}{lr}\text { Bryan, } & 1940 ; \\
\text { Love } & \text { and } \\
\text { Seager, } 1996\end{array}$ \\
\hline 15 & $\begin{array}{l}\text { Lake Tecopa, } \\
\text { Nevada, CA }\end{array}$ & $\begin{array}{l}\text { Inverted } \\
\text { topography }\end{array}$ & $\begin{array}{l}\text { Channel fill } \\
\text { cementation }\end{array}$ & Quaternary & Subtropical & $\begin{array}{l}\text { Morrison and } \\
\text { Mifflin (2000) }\end{array}$ \\
\hline
\end{tabular}




\begin{tabular}{|c|c|c|c|c|c|c|}
\hline 16 & $\begin{array}{l}\text { The Black } \\
\text { Canyon, } \\
\text { Colorado }\end{array}$ & $\begin{array}{l}\text { Inverted } \\
\text { topography }\end{array}$ & Volcanism & Miocene & Subtropical & $\begin{array}{l}\text { Sandoval } \\
(2007)\end{array}$ \\
\hline 17 & $\begin{array}{l}\text { Snow Canyon } \\
\text { State Park, } \\
\text { Utah }\end{array}$ & $\begin{array}{l}\text { Inverted } \\
\text { topography }\end{array}$ & Volcanism & Quaternary & Subtropical & Higgins, 2000 \\
\hline 18 & $\begin{array}{l}\text { Harrisonburg, } \\
\text { Virginia }\end{array}$ & $\begin{array}{l}\text { Inverted } \\
\text { topography }\end{array}$ & $\begin{array}{l}\text { Channel fill } \\
\text { cementation }\end{array}$ & $?$ & Temperate & $\begin{array}{l}\text { Doctor et al., } \\
2014\end{array}$ \\
\hline 19 & $\begin{array}{l}\text { Grand Canyon } \\
\text { region }\end{array}$ & $\begin{array}{l}\text { Inverted } \\
\text { topography }\end{array}$ & Volcanism & Pliocene & Subtropical & $\begin{array}{l}\text { Karlstorm et } \\
\text { al., } 2017\end{array}$ \\
\hline 20 & $\begin{array}{l}\text { Green Valley- } \\
\text { Tubac area, } \\
\text { southeastern } \\
\text { Arizona }\end{array}$ & $\begin{array}{l}\text { Inverted } \\
\text { topography }\end{array}$ & $\begin{array}{l}\text { Channel fill } \\
\text { cementation }\end{array}$ & Quaternary & Subtropical & $\begin{array}{l}\text { Lindsey et al., } \\
\text { 2005; } \\
\text { Knepper, } \\
\text { 2005; Lindsey } \\
\text { and Van } \\
\text { Gosen, } 2010\end{array}$ \\
\hline 21 & $\begin{array}{l}\text { North-central } \\
\text { Texas }\end{array}$ & $\begin{array}{l}\text { Exhumed point } \\
\text { bars }\end{array}$ & $\begin{array}{l}\text { Channel fill } \\
\text { lithification }\end{array}$ & Lower Permian & Subtropical & $\begin{array}{l}\text { Edwards et al., } \\
1983\end{array}$ \\
\hline 22 & $\begin{array}{l}\text { Wasatch } \\
\text { Formation, } \\
\text { western } \\
\text { Colorado }\end{array}$ & $\begin{array}{l}\text { Exhumed } \\
\text { channels }\end{array}$ & $\begin{array}{l}\text { Channel fill } \\
\text { lithification }\end{array}$ & Eocene & Subtropical & $\begin{array}{l}\text { Mohrig et al., } \\
2000\end{array}$ \\
\hline 23 & $\begin{array}{l}\text { Notom Delta, } \\
\text { South-central } \\
\text { Utah }\end{array}$ & Paleochannels & $\begin{array}{l}\text { Channel fill } \\
\text { lithification }\end{array}$ & Cretaceous & Subtropical & $\begin{array}{l}\text { Wang and } \\
\text { Bhattacharya, } \\
2018\end{array}$ \\
\hline 24 & $\begin{array}{ll}\text { St. } & \text { George, } \\
\text { Utah } & \\
\end{array}$ & Inverted valleys & Volcanism & $1.07-2.3 \mathrm{Ma}$ & Subtropical & $\begin{array}{l}\text { Williams et al } \\
2007\end{array}$ \\
\hline 25 & $\begin{array}{l}\text { Mojave } \\
\text { Desert, CA }\end{array}$ & $\begin{array}{l}\text { Inverted } \\
\text { topography }\end{array}$ & $\begin{array}{l}\text { Channel fill } \\
\text { cementation }\end{array}$ & $\begin{array}{l}\text { Pleistocene and } \\
\text { Holocene }\end{array}$ & Subtropical & $\begin{array}{l}\text { McDonald et } \\
\text { al., } 2003\end{array}$ \\
\hline 26 & $\begin{array}{l}\text { Coconino } \\
\text { County, } \\
\text { Northern } \\
\text { Arizona }\end{array}$ & $\begin{array}{l}\text { Inverted } \\
\text { topography }\end{array}$ & volcanism & $\begin{array}{l}\text { Pliocene and } \\
\text { Pleistocene }\end{array}$ & Subtropical & $\begin{array}{l}\text { Billingsley et } \\
\text { al., } 2007\end{array}$ \\
\hline
\end{tabular}




\begin{tabular}{|c|c|c|c|c|c|c|c|}
\hline 27 & & $\begin{array}{l}\text { Quinn River, } \\
\text { Nevada }\end{array}$ & $\begin{array}{l}\text { Inverted relief; } \\
\text { inverted } \\
\text { abandoned } \\
\text { channel }\end{array}$ & $\begin{array}{l}\text { Channel fill } \\
\text { cementation }\end{array}$ & $?$ & Subtropical & $\begin{array}{l}\text { Matsubara et } \\
\text { al., } 2015\end{array}$ \\
\hline 28 & & $\begin{array}{l}\text { Eastern } \\
\text { Montana } \\
\text { Western North } \\
\text { Dakota }\end{array}$ & $\begin{array}{l}\text { Inverted } \\
\text { topography }\end{array}$ & $\begin{array}{l}\text { Surface } \\
\text { armouring? }\end{array}$ & $?$ & Temperate & Clausen 2018 \\
\hline 29 & & $\begin{array}{l}\text { Colorado } \\
\text { Piedmont }\end{array}$ & $\begin{array}{l}\text { Inverted } \\
\text { topography }\end{array}$ & $\begin{array}{l}\text { Channel fill } \\
\text { cementation }\end{array}$ & Late Eocene & Subtropical & $\begin{array}{l}\text { Morgan et al. } \\
2008\end{array}$ \\
\hline 30 & & $\begin{array}{l}\text { Near Boulder, } \\
\text { Utah }\end{array}$ & $\begin{array}{l}\text { Inverted } \\
\text { Pleistocene } \\
\text { paleovalley }\end{array}$ & $\begin{array}{l}\text { Channel fill } \\
\text { cementation }\end{array}$ & Pliestocene & Subtropical & $\begin{array}{l}\text { Loope et al., } \\
2016\end{array}$ \\
\hline 31 & Mexico & Michoacán & $\begin{array}{l}\text { Inverted } \\
\text { topography }\end{array}$ & Volcanism & Late Pliocene & Subtropical & $\begin{array}{l}\text { Guilbaud et } \\
\text { al., } 2011\end{array}$ \\
\hline \multicolumn{8}{|c|}{ Africa } \\
\hline 1 & Egypt & $\begin{array}{l}\text { Egyptian } \\
\text { Nubia }\end{array}$ & $\begin{array}{l}\text { Inverted wadis; } \\
\text { perched ridges; } \\
\text { wadi ridges; } \\
\text { wadi } \\
\text { conglomerate }\end{array}$ & $\begin{array}{l}\text { Channel fill } \\
\text { cementation; } \\
\text { surface } \\
\text { armouring }\end{array}$ & Late Quaternary & Subtropical & $\begin{array}{l}\text { (Giegengack, } \\
\text { 1968; Butzer } \\
\text { and Hansen, } \\
\text { 1968; Haynes, } \\
\text { 1980; Zaki } \\
\text { and } \\
\text { Giegengack, } \\
\text { 2016; } \\
\text { Giegengack } \\
\text { and Zaki, } \\
\text { 2017; Zaki et } \\
\text { al., 2018) }\end{array}$ \\
\hline 2 & & $\begin{array}{l}\text { Dakhla } \\
\text { Depression }\end{array}$ & $\begin{array}{l}\text { Exhumed } \\
\text { meander scorlls; } \\
\text { inverted stream } \\
\text { channels }\end{array}$ & $\begin{array}{l}\text { Channel fill } \\
\text { lithification }\end{array}$ & Upper Cretaceous & Subtropical & $\begin{array}{l}\text { (Brookes, } \\
\text { 2003; Zaki et } \\
\text { al., 2018) }\end{array}$ \\
\hline
\end{tabular}




\begin{tabular}{|c|c|c|c|c|c|c|c|}
\hline 3 & & $\begin{array}{l}\text { West of Ghard } \\
\text { Abu Muharik }\end{array}$ & $\begin{array}{l}\text { Inverted wadi; } \\
\text { inverted stream } \\
\text { channels }\end{array}$ & $\begin{array}{l}\text { Channel fill } \\
\text { cementation }\end{array}$ & $\begin{array}{l}\text { Oligocene - } \\
\text { Miocene }\end{array}$ & Subtropical & $\begin{array}{l}\text { (Brookes, } \\
\text { 2001; Embabi, } \\
\text { 2004; Zaki et } \\
\text { al., 2018) }\end{array}$ \\
\hline 4 & & $\begin{array}{l}\text { West of Esna } \\
\text { city and east } \\
\text { of Kharga } \\
\text { Depression }\end{array}$ & $\begin{array}{l}\text { Inverted wadi; } \\
\text { inverted stream } \\
\text { channels }\end{array}$ & $\begin{array}{l}\text { Channel fill } \\
\text { cementation }\end{array}$ & $\begin{array}{l}\text { Oligocene - } \\
\text { Miocene }\end{array}$ & Subtropical & $\begin{array}{l}\text { (Zaki et al., } \\
\text { 2018) }\end{array}$ \\
\hline 5 & & $\begin{array}{l}\text { Kharga } \\
\text { Depression }\end{array}$ & $\begin{array}{l}\text { Inverted } \\
\text { channels }\end{array}$ & $\begin{array}{l}\text { Channel fill } \\
\text { cementation }\end{array}$ & $225 \pm 40$ years & Subtropical & Busche (1988) \\
\hline 6 & & $\begin{array}{l}\text { Tushka } \\
\text { paleolake }\end{array}$ & $\begin{array}{l}\text { Inverted deltaic } \\
\text { features }\end{array}$ & $\begin{array}{l}\text { Channel fill } \\
\text { cementation }\end{array}$ & Pleistocene & Subtropical & This study \\
\hline 7 & & $\begin{array}{l}\text { Fayum } \\
\text { Depression }\end{array}$ & $\begin{array}{l}\text { Inverted stream } \\
\text { channels }\end{array}$ & $\begin{array}{l}\text { Channel fill } \\
\text { cementation }\end{array}$ & Pliocene & Subtropical & $\begin{array}{l}\text { (Sandford and } \\
\text { Arkell, 1929; } \\
\text { Aref, 2003; } \\
\text { Embabi, 2004; } \\
\text { Zaki et al., } \\
\text { 2018) }\end{array}$ \\
\hline 8 & & $\begin{array}{l}\text { west of } \\
\text { Bahariya } \\
\text { Depression } \\
\end{array}$ & $\begin{array}{l}\text { Inverted stream } \\
\text { channels }\end{array}$ & $\begin{array}{l}\text { Channel fill } \\
\text { cementation }\end{array}$ & $?$ & Subtropical & $\begin{array}{l}\text { (Zaki et al., } \\
\text { 2018) }\end{array}$ \\
\hline 9 & $\begin{array}{l}\text { South } \\
\text { Africa }\end{array}$ & East Victoria & $\begin{array}{l}\text { Gravel-capped } \\
\text { ridges }\end{array}$ & $\begin{array}{l}\text { Channel fill } \\
\text { cementation }\end{array}$ & $?$ & Subtropical & (King, 1942) \\
\hline 10 & & $\begin{array}{l}\text { SW Kalahari } \\
\text { and } \\
\text { Kalkweissrand } \\
\end{array}$ & $\begin{array}{l}\text { Inverted relief; } \\
\text { inverted } \\
\text { topography }\end{array}$ & $\begin{array}{l}\text { Channel fill } \\
\text { cementation } \\
\text { (calcrete) } \\
\end{array}$ & $?$ & Subtropical & (Shaw, 2009) \\
\hline 11 & & Kgalagadi & $\begin{array}{l}\text { Inverted relief; } \\
\text { inverted } \\
\text { topography }\end{array}$ & $\begin{array}{l}\text { Channel fill } \\
\text { cementation } \\
\text { (calcrete) } \\
\end{array}$ & $?$ & Subtropical & (Shaw, 2009) \\
\hline 12 & Mali & $\begin{array}{l}\text { Djelimagara } \\
\text { pleateau }\end{array}$ & Relief inversion & $\begin{array}{l}\text { Channel fill } \\
\text { cementation }\end{array}$ & Paleocene & Tropical & $\begin{array}{l}\text { (Butt and } \\
\text { Bristow, 2013) }\end{array}$ \\
\hline 13 & & $\begin{array}{l}\text { Tambaoura } \\
\text { escarpment }\end{array}$ & Relief inveriosn & $\begin{array}{l}\text { Channel fill } \\
\text { cementation }\end{array}$ & Paleocene & Tropical & $\begin{array}{l}\text { Butt and } \\
\text { Bristow, 2013) }\end{array}$ \\
\hline
\end{tabular}




\begin{tabular}{|c|c|c|c|c|c|c|c|}
\hline 14 & & $\begin{array}{l}\text { Banankoro } \\
\text { cuirasse }\end{array}$ & Relief inversion & $\begin{array}{l}\text { Channel fill } \\
\text { cementation }\end{array}$ & Paleocene & Tropical & $\begin{array}{l}\text { (Butt and } \\
\text { Bristow, 2013) }\end{array}$ \\
\hline 15 & & $\begin{array}{l}\text { Misseni- } \\
\text { Tabakaroni }\end{array}$ & Relief inversion & $\begin{array}{l}\text { Channel fill } \\
\text { cementation }\end{array}$ & Paleocene & Tropical & $\begin{array}{l}\text { (Butt and } \\
\text { Bristow, 2013) }\end{array}$ \\
\hline 16 & & $\begin{array}{l}\text { Kalako } \\
\text { plateau }\end{array}$ & Relief inversion & $\begin{array}{l}\text { Channel fill } \\
\text { cementation }\end{array}$ & Paleocene & Tropical & $\begin{array}{l}\text { (Butt and } \\
\text { Bristow, 2013) }\end{array}$ \\
\hline 17 & $\begin{array}{l}\text { Burkina } \\
\text { Faso }\end{array}$ & Fouli plateau & Relief inversion & $\begin{array}{l}\text { Channel fill } \\
\text { cementation }\end{array}$ & Paleocene & Tropical & $\begin{array}{l}\text { (Butt and } \\
\text { Bristow, 2013) }\end{array}$ \\
\hline 18 & & $\begin{array}{l}\text { Dave plain \& } \\
\text { scarp }\end{array}$ & Relief inversion & $\begin{array}{l}\text { Channel fill } \\
\text { cementation }\end{array}$ & Paleocene & Tropical & $\begin{array}{l}\text { (Butt and } \\
\text { Bristow, 2013) }\end{array}$ \\
\hline 19 & & $\begin{array}{l}\text { Donko } \\
\text { pleateau }\end{array}$ & Relief inversion & $\begin{array}{l}\text { Channel fill } \\
\text { cementation }\end{array}$ & Paleocene & Tropical & $\begin{array}{l}\text { (Butt and } \\
\text { Bristow, 2013) }\end{array}$ \\
\hline 20 & & $\begin{array}{l}\text { Konkera } \\
\text { plateau }\end{array}$ & Relief inversion & $\begin{array}{l}\text { Channel fill } \\
\text { cementation }\end{array}$ & Paleocene & Tropical & $\begin{array}{l}\text { (Butt and } \\
\text { Bristow, 2013) }\end{array}$ \\
\hline 21 & & SW region & Relief inversion & $\begin{array}{l}\text { Channel fill } \\
\text { cementation }\end{array}$ & $?$ & Tropical & $\begin{array}{l}\text { (Chardon et al, } \\
\text { 2018) }\end{array}$ \\
\hline 22 & Ethiopia & $\begin{array}{l}\text { Lake Turkana } \\
\text { (North } \\
\text { Rudolph) }\end{array}$ & $\begin{array}{l}\text { Inverted } \\
\text { channels }\end{array}$ & $\begin{array}{l}\text { Channel fill } \\
\text { cementation }\end{array}$ & Holocene & Tropical & (Butzer, 1980) \\
\hline 23 & & Ogaden & $\begin{array}{l}\text { Inverted } \\
\text { topography }\end{array}$ & Volcanism & $?$ & Tropical & $\begin{array}{l}\text { (Wiliams, } \\
\text { 2016) }\end{array}$ \\
\hline 24 & $\begin{array}{l}\text { Libya and } \\
\text { Algeria }\end{array}$ & $\begin{array}{l}\text { Tassili } \\
\text { N'Ajjer }\end{array}$ & $\begin{array}{l}\text { Channelized } \\
\text { sandstone } \\
\text { bodies }\end{array}$ & $\begin{array}{l}\text { Sediment } \\
\text { lithification }\end{array}$ & Late Ordovician & Tropical & $\begin{array}{l}\text { (Girard et al., } \\
\text { 2012) }\end{array}$ \\
\hline 25 & Chad & $\begin{array}{l}\text { Bodélé } \\
\text { Depression }\end{array}$ & $\begin{array}{l}\text { Inverted } \\
\text { channel } \\
\text { topography }\end{array}$ & $\begin{array}{l}\text { Channel fill } \\
\text { cementation }\end{array}$ & $2.4 \mathrm{ka}$ (OSL dating) & Tropical & $\begin{array}{l}\text { Bristow et al., } \\
\text { 2009; Schuster } \\
\text { et al., } 2005\end{array}$ \\
\hline 26 & & $\begin{array}{l}\text { Angamma } \\
\text { Delta }\end{array}$ & $\begin{array}{l}\text { Inverted } \\
\text { channels }\end{array}$ & $\begin{array}{l}\text { Channel fill } \\
\text { cementation }\end{array}$ & Late Quaternary & Tropical & This study \\
\hline 27 & Botswana & $\begin{array}{l}\text { Okavango } \\
\text { Delta }\end{array}$ & $\begin{array}{l}\text { Inverted } \\
\text { topography }\end{array}$ & $\begin{array}{l}\text { Compaction } \\
\text { of volume of } \\
\text { bank- } \\
\text { forming peat }\end{array}$ & $?$ & Tropical & $\begin{array}{l}\text { (Ellery et al., } \\
1989 ; \\
\text { Gumbright et } \\
\text { al., 2004) }\end{array}$ \\
\hline
\end{tabular}




\begin{tabular}{|c|c|c|c|c|c|c|c|}
\hline 28 & & Bosutswe & $\begin{array}{l}\text { Inverted } \\
\text { topography }\end{array}$ & $\begin{array}{l}\text { Channel fill } \\
\text { cementation }\end{array}$ & Quaternary & Subtropical & $\begin{array}{l}\text { (Denbow et } \\
\text { al., 2008) }\end{array}$ \\
\hline 29 & & Kalahari & $\begin{array}{l}\text { Channel and } \\
\text { valley calcrete }\end{array}$ & $\begin{array}{l}\text { Channel fill } \\
\text { cementation }\end{array}$ & $?$ & Subtropical & $\begin{array}{l}\text { Nash and } \\
\text { McLaren, } \\
\text { 2003) }\end{array}$ \\
\hline 30 & & $\begin{array}{l}\text { Linyanti, } \\
\text { Okavango and } \\
\text { Ngami }\end{array}$ & $\begin{array}{l}\text { Inverted relief; } \\
\text { inverted } \\
\text { topography }\end{array}$ & $\begin{array}{l}\text { Channel fill } \\
\text { cementation } \\
\text { (calcrete) }\end{array}$ & $?$ & Subtropical & (Shaw, 2009) \\
\hline 31 & Kenya & Lake Bogoria & $\begin{array}{l}\text { Inverted } \\
\text { topography }\end{array}$ & $\begin{array}{l}\text { Channel fill } \\
\text { cementation }\end{array}$ & Holocene & Tropical & $\begin{array}{l}\text { (Renaut et al., } \\
\text { 2013) }\end{array}$ \\
\hline 32 & Sudan & Wadi Awatib & $\begin{array}{l}\text { Inverted gravel } \\
\text { ridges }\end{array}$ & $\begin{array}{l}\text { Channel fill } \\
\text { cementation; } \\
\text { Volcanism }\end{array}$ & $\begin{array}{l}\text { Messinain to early } \\
\text { Pliocene }\end{array}$ & Subtropical & $\begin{array}{l}\text { (Bussert et al., } \\
\text { 2018) }\end{array}$ \\
\hline 33 & & Kordofan & Relief inversion & $\begin{array}{l}\text { Channel fill } \\
\text { cementation }\end{array}$ & Miocene & Subtropical & $\begin{array}{l}\text { (Schwarz, } \\
\text { 1994) }\end{array}$ \\
\hline 34 & Niger & $\begin{array}{l}\text { Northern } \\
\text { Niger }\end{array}$ & $\begin{array}{l}\text { Inverted } \\
\text { topography }\end{array}$ & $\begin{array}{l}\text { Sediment } \\
\text { lithification }\end{array}$ & Late Permian & Tropical & $\begin{array}{l}\text { (Smith et al., } \\
\text { 2015) }\end{array}$ \\
\hline 35 & Zimbabwe & Bulawayo & $\begin{array}{l}\text { Inverted } \\
\text { topography }\end{array}$ & $\begin{array}{l}\text { Channel fill } \\
\text { lithification }\end{array}$ & Oligocene & Tropical & $\begin{array}{l}\text { (Moore et al., } \\
\text { 2009; Moore } \\
\text { et al., 2012) }\end{array}$ \\
\hline 36 & Morocco & Tindouf basin & Point bar ridges & $\begin{array}{l}\text { Channel fill } \\
\text { lithification }\end{array}$ & Late Carboniferous & Subtropical & $\begin{array}{l}\text { Padgett and } \\
\text { Ehrlich (1976) }\end{array}$ \\
\hline 37 & $\begin{array}{l}\text { Burkina } \\
\text { Faso }\end{array}$ & Western part & $\begin{array}{l}\text { Inverted } \\
\text { topography }\end{array}$ & $\begin{array}{l}\text { Channel fill } \\
\text { cementation }\end{array}$ & $?$ & Tropical & $\begin{array}{l}\text { Zeegers and } \\
\text { Lecomte } \\
(1992)\end{array}$ \\
\hline 38 & Tanzania & $\begin{array}{l}\text { Olduvai } \\
\text { Gorge }\end{array}$ & $\begin{array}{l}\text { Inverted } \\
\text { topography }\end{array}$ & $\begin{array}{l}\text { Channel fill } \\
\text { cementation }\end{array}$ & Quaternary & Tropical & $\begin{array}{l}\text { Blumenschime } \\
\text { et al., } 2012\end{array}$ \\
\hline 39 & Namibia & Etosha & $\begin{array}{l}\text { Inverted relief; } \\
\text { inverted } \\
\text { topography }\end{array}$ & $\begin{array}{l}\text { Channel fill } \\
\text { cementation } \\
\text { (calcrete) }\end{array}$ & $?$ & Subtropical & (Shaw, 2009) \\
\hline 40 & & Oase & $\begin{array}{l}\text { Topographically } \\
\text { inverted }\end{array}$ & $\begin{array}{l}\text { Channel fill } \\
\text { cementation } \\
\text { (calcrete) }\end{array}$ & $?$ & Tropical & $\begin{array}{l}\text { Smith and } \\
\text { Mason, } 1998\end{array}$ \\
\hline
\end{tabular}




\begin{tabular}{|c|c|c|c|c|c|c|c|}
\hline 41 & Somalia & $\begin{array}{l}\text { Upper Jubba } \\
\text { Valley }\end{array}$ & Fossil drainage & volcanism & Tertiary & Tropical & $\begin{array}{l}\text { Abdirahim et } \\
\text { al., } 1993\end{array}$ \\
\hline \multicolumn{8}{|c|}{ Australia } \\
\hline 1 & Australia & $\begin{array}{l}\text { Mirackina, } \\
\text { Arckaringa, } \\
\text { South } \\
\text { Australia }\end{array}$ & $\begin{array}{l}\text { Exhumed } \\
\text { paleodrainage; } \\
\text { Inverted } \\
\text { topography }\end{array}$ & $\begin{array}{l}\text { Channel fill } \\
\text { cementation }\end{array}$ & Miocene & Tropical & $\begin{array}{l}\text { (Barnes and } \\
\text { Pitt, 1976; } \\
\text { Pain and } \\
\text { Ollier, 1995; } \\
\text { McNally and } \\
\text { Wilson, 1996; } \\
\text { Hou et al., } \\
\text { 2007) }\end{array}$ \\
\hline 2 & & $\begin{array}{l}\text { El Capitan, } \\
\text { NE of Cobar, } \\
\text { N.S.W. }\end{array}$ & Inverted relief & $\begin{array}{l}\text { Volcanism } \\
\text { (leucitite } \\
\text { flows) }\end{array}$ & $17 \mathrm{Ma}$ & Tropical & $\begin{array}{l}\text { Cundari and } \\
\text { Ollier, 1970; } \\
\text { Cohen et al., } \\
2007\end{array}$ \\
\hline 3 & & $\begin{array}{l}\text { Kalgoorlie } \\
\text { region, } \\
\text { Western } \\
\text { Australia } \\
\end{array}$ & Duricrusts & $\begin{array}{l}\text { Channel fill } \\
\text { cementation }\end{array}$ & Eocene & Subtropical & $\begin{array}{l}\text { Ollier et al., } \\
1988\end{array}$ \\
\hline 4 & & $\begin{array}{l}\text { Bullengarook, } \\
\text { West of } \\
\text { Melbourne, } \\
\text { Victoria }\end{array}$ & Inverted relief & Volcanism & $?$ & Subtropical & $\begin{array}{l}\text { Pain and } \\
\text { Ollier, } 1995\end{array}$ \\
\hline 5 & & $\begin{array}{l}\text { Campaspe and } \\
\text { Coliban } \\
\text { Rivers, } \\
\text { Victoria }\end{array}$ & Inverted relief & Volcanism & $?$ & Subtropical & $\begin{array}{l}\text { Pain and } \\
\text { Ollier, } 1995\end{array}$ \\
\hline 6 & & $\begin{array}{l}\text { Robe River, } \\
\text { Western } \\
\text { Australia }\end{array}$ & Inverted relief & $\begin{array}{l}\text { Channel fill } \\
\text { cementation }\end{array}$ & Eocene & Tropical & $\begin{array}{l}\text { Macleod, } \\
\text { 1966; Twidale } \\
\text { et al., 1985; } \\
\text { Hall and } \\
\text { Kneeshaw, }\end{array}$ \\
\hline
\end{tabular}




\begin{tabular}{|c|c|c|c|c|c|c|c|}
\hline & & & & & & & $\begin{array}{l}\text { 1990; Dalstra } \\
\text { et al., } 2010\end{array}$ \\
\hline 7 & & $\begin{array}{l}\text { Cape York } \\
\text { Peninsula. }\end{array}$ & Inverted relief & $\begin{array}{l}\text { Channel fill } \\
\text { cementation }\end{array}$ & $?$ & Tropical & $\begin{array}{l}\text { Pain and } \\
\text { Ollier, } 1995\end{array}$ \\
\hline 8 & & $\begin{array}{l}\text { Southwest } \\
\text { Australia }\end{array}$ & Inverted relief & $\begin{array}{l}\text { Channel fill } \\
\text { lithification; } \\
\text { Channel fill } \\
\text { cementation }\end{array}$ & $\begin{array}{l}\text { Permian, Jurassic, } \\
\text { Cretaceous, Eocene, } \\
\text { and Quaternary }\end{array}$ & Subtropical & $\begin{array}{l}\text { Fairbridge and } \\
\text { Finkl, 1978; } \\
\text { Finkl and } \\
\text { Fairbridge, } \\
\text { 1979; Pain and } \\
\text { Ollier, 1995 }\end{array}$ \\
\hline 9 & & $\begin{array}{l}\text { Lawlers area, } \\
\text { Western } \\
\text { Australia }\end{array}$ & Inverted relief & $\begin{array}{l}\text { Channel fill } \\
\text { cementation }\end{array}$ & $?$ & Subtropical & $\begin{array}{l}\text { Pain and } \\
\text { Ollier, 1995; } \\
\text { Anand and } \\
\text { Smith, 1993 }\end{array}$ \\
\hline 10 & & Queensland & Inverted relief & $\begin{array}{l}\text { Channel fill } \\
\text { cementation }\end{array}$ & $?$ & Tropical & $\begin{array}{l}\text { Pain and } \\
\text { Ollier, } 1995\end{array}$ \\
\hline 11 & & $\begin{array}{l}\text { Ashburton } \\
\text { Valley, } \\
\text { Western } \\
\text { Australia }\end{array}$ & $\begin{array}{l}\text { Perched } \\
\text { calcretes }\end{array}$ & $\begin{array}{l}\text { Channel fill } \\
\text { cementation }\end{array}$ & $?$ & Subtropical & $\begin{array}{l}\text { Mann and } \\
\text { Horwitz } 1979\end{array}$ \\
\hline \multicolumn{8}{|c|}{ Asia } \\
\hline 1 & $\begin{array}{l}\text { Saudi } \\
\text { Arabia }\end{array}$ & $\begin{array}{l}\text { Eastern Saudi } \\
\text { Arabia }\end{array}$ & $\begin{array}{l}\text { Suspendritic } \\
\text { drainage lines }\end{array}$ & $\begin{array}{l}\text { Channel fill } \\
\text { cementation }\end{array}$ & $?$ & Subtropical & (Miller, 1937) \\
\hline 2 & & $\begin{array}{l}\text { Wadi Ad } \\
\text { Dawsir and } \\
\text { Wadi Sabha }\end{array}$ & $\begin{array}{l}\text { Inverted } \\
\text { topography }\end{array}$ & $\begin{array}{l}\text { Channel fill } \\
\text { cementation }\end{array}$ & $\begin{array}{l}3.7 \pm 0.3 \mathrm{ka}-109 \pm \\
6 \mathrm{ka}(\mathrm{OSL}) ; 6360 \pm \\
50-7770 \pm 50 \text { years } \\
(\mathrm{C} 14)\end{array}$ & Subtropical & $\begin{array}{l}\text { Matter et al., } \\
2016\end{array}$ \\
\hline 3 & Kuwait & Wadi Al-Batin & Inverted courses & $\begin{array}{l}\text { Channel fill } \\
\text { cementation }\end{array}$ & Quaternary & Subtropical & Holm, 1960 \\
\hline 4 & Oman & Wadi Wahiba & $\begin{array}{l}\text { Raised channel } \\
\text { systems }\end{array}$ & $\begin{array}{l}\text { Channel fill } \\
\text { cementation }\end{array}$ & $\begin{array}{l}\text { Pliocene to } \\
\text { Pleistocene }\end{array}$ & Tropical & $\begin{array}{l}\text { Beydoun, } \\
\text { 1980; Maizels, } \\
\text { 1983, 1987, } \\
1990\end{array}$ \\
\hline
\end{tabular}




\begin{tabular}{|c|c|c|c|c|c|c|c|}
\hline 5 & Syria & Syrian Desert & Extinct wadis & $\begin{array}{l}\text { Channel fill } \\
\text { cementation }\end{array}$ & $?$ & Subtropical & Wright, 1958 \\
\hline 6 & China & $\begin{array}{l}\text { Kumtagh } \\
\text { Desert }\end{array}$ & Gravel bodies & $\begin{array}{l}\text { Channel fill } \\
\text { cementation } \\
\text { and surface } \\
\text { armouring }\end{array}$ & $151 \mathrm{ka}(\mathrm{OSL})$ & Subtropical & $\begin{array}{l}\text { Wang et al., } \\
2017\end{array}$ \\
\hline 7 & & $\begin{array}{l}\text { Yangtze } \\
\text { Valley, China }\end{array}$ & $\begin{array}{l}\text { Inverted } \\
\text { topography }\end{array}$ & Volcanism & Early Cenozoic & Tropical & $\begin{array}{l}\text { Teilhard de } \\
\text { Chardin, } \\
\text { Young, } 1935\end{array}$ \\
\hline 8 & & Lop-Nor & $\begin{array}{l}\text { Inverted } \\
\text { rivercourses }\end{array}$ & $\begin{array}{l}\text { Channel fill } \\
\text { cementation }\end{array}$ & $?$ & Subtropical & Hörner, 1932 \\
\hline 9 & Israel & Negev Desert & Inverted relief & $\begin{array}{l}\text { Channel fill } \\
\text { cementation }\end{array}$ & $?$ & Subtropical & (Migon, 2004) \\
\hline 10 & India & $\begin{array}{l}\text { Matheran } \\
\text { tableland }\end{array}$ & Inverted relief & $\begin{array}{l}\text { Channel fill } \\
\text { cementation; } \\
\text { Volcanism }\end{array}$ & $?$ & Tropical & $\begin{array}{l}\text { Ollier and } \\
\text { Sheth, } 2008\end{array}$ \\
\hline 11 & & $\begin{array}{l}\text { Western Ghats } \\
\text { escarpment }\end{array}$ & Inverted relief & $\begin{array}{l}\text { Channel fill } \\
\text { cementation }\end{array}$ & $?$ & Tropical & $\begin{array}{l}\text { Ollier and } \\
\text { Sheth, } 2008\end{array}$ \\
\hline 12 & & West Bengal & Inverted relief & $\begin{array}{l}\text { Channel fill } \\
\text { cementation } \\
\text { (ferricrete) }\end{array}$ & $150-35 \mathrm{ka}(\mathrm{OSL})$ & Tropical & $\begin{array}{l}\text { Ghosh and } \\
\text { Guchhait } 2019\end{array}$ \\
\hline 13 & & $\begin{array}{l}\text { Thar Desert, } \\
\text { Merta, } \\
\text { Rajasthan }\end{array}$ & $\begin{array}{l}\text { Calcrete and } \\
\text { gypsum crusts }\end{array}$ & $\begin{array}{l}\text { Channel fill } \\
\text { cementation }\end{array}$ & Late Quaternary & Tropical & Kar, 2011 \\
\hline \multicolumn{8}{|c|}{ South America } \\
\hline 1 & Argentina & $\begin{array}{l}\text { Cañadón } \\
\text { Asfalto Basin }\end{array}$ & $\begin{array}{l}\text { Exhumed } \\
\text { fluvial system }\end{array}$ & \begin{tabular}{|l|} 
Sediment \\
lithification
\end{tabular} & Cretaceous & Subtropical & $\begin{array}{l}\text { Foix et al., } \\
2012\end{array}$ \\
\hline 2 & & $\begin{array}{l}\text { Cerro Galán } \\
\text { Ignimbrite }\end{array}$ & $\begin{array}{l}\text { Inverted } \\
\text { topography }\end{array}$ & volcanism & $\begin{array}{l}\text { Pliocene and } \\
\text { Pleistocene }\end{array}$ & Subtropical & $\begin{array}{l}\text { Cas et al., } \\
2011\end{array}$ \\
\hline 3 & & $\begin{array}{l}\text { Pinguino, } \\
\text { Santa Cruz } \\
\text { Province }\end{array}$ & $\begin{array}{l}\text { Inverted } \\
\text { topography }\end{array}$ & Volcanism & Cretaceous & Temperate & $\begin{array}{l}\text { Ristorcelli et } \\
\text { al., } 2013\end{array}$ \\
\hline
\end{tabular}




\begin{tabular}{|c|c|c|c|c|c|c|c|}
\hline 4 & Colombia & $\begin{array}{l}\text { Frío River } \\
\text { valley, } \\
\text { Colombia }\end{array}$ & Inverted relief & Volcanism & $?$ & Tropical & $\begin{array}{l}\text { Caballero et } \\
\text { al., } 2016\end{array}$ \\
\hline 5 & & $\begin{array}{l}\text { Nevado del } \\
\text { Tolima and } \\
\text { Cerro Machin, } \\
\text { Colombia }\end{array}$ & Inverted relief & Volcanism & Quaternary & Tropical & $\begin{array}{l}\text { Thouret et al., } \\
1995\end{array}$ \\
\hline 6 & Chile & $\begin{array}{l}\text { Atacama } \\
\text { Desert }\end{array}$ & $\begin{array}{l}\text { Inverted } \\
\text { topographic } \\
\text { features }\end{array}$ & $\begin{array}{l}\text { Surface } \\
\text { armouring; } \\
\text { Potential } \\
\text { Channel fill } \\
\text { cementation }\end{array}$ & $?$ & Subtropical & $\begin{array}{l}\text { Morgan et al. } \\
\text { (2014) }\end{array}$ \\
\hline 7 & Peru & $\begin{array}{l}\text { Lower Ica } \\
\text { Valley }\end{array}$ & Inverted relief & $\begin{array}{l}\text { Channel fill } \\
\text { cementation } \\
\text { calcrete }\end{array}$ & 2,000 years & Tropical & $\begin{array}{l}\text { Beresford- } \\
\text { Jones et al. } \\
2009\end{array}$ \\
\hline \multicolumn{8}{|c|}{ Europe } \\
\hline 1 & Spain & Ebro basin & $\begin{array}{l}\text { Exhumed } \\
\text { channels, ribbon } \\
\text { sandstones }\end{array}$ & $\begin{array}{l}\text { Channel fill } \\
\text { cementation } \\
\text { and channel } \\
\text { fill } \\
\text { lithification }\end{array}$ & Oligocene-Miocene & Subtropical & $\begin{array}{l}\text { (Friend et al., } \\
\text { 1981; Mohrig } \\
\text { et al., 2000; } \\
\text { Cuevas et al., } \\
\text { 2010) }\end{array}$ \\
\hline 2 & Scotland & Isle of Skye & $\begin{array}{l}\text { Inverted } \\
\text { topographic ; } \\
\text { inverted relief }\end{array}$ & Volcanism & Paleocene & Temperate & $\begin{array}{l}\text { Bell and } \\
\text { Williamson, } \\
2013\end{array}$ \\
\hline \multicolumn{8}{|c|}{ Mediterranean Sea } \\
\hline 1 & $\begin{array}{l}\text { Offshore } \\
\text { Cyprus, } \\
\text { Syria, } \\
\text { Lebanon } \\
\text { and Israel }\end{array}$ & & $\begin{array}{l}\text { Inverted } \\
\text { topography }\end{array}$ & $\begin{array}{l}\text { Sediment } \\
\text { lithification }\end{array}$ & Late Miocene & Subtropical & $\begin{array}{l}\text { Madof et al., } \\
2019\end{array}$ \\
\hline
\end{tabular}

